Health and Condition of Endangered Juvenile Lost River and Shortnose Suckers Relative to Water Quality and Fish Assemblages in Upper Klamath Lake, Oregon, and Clear Lake Reservoir, California

Open-File Report 2015-1217 



\section{Health and Condition of Endangered Juvenile Lost River and Shortnose Suckers Relative to Water Quality and Fish Assemblages in Upper Klamath Lake, Oregon, and Clear Lake Reservoir, California}

By Summer M. Burdick, Diane G. Elliott, Carl O. Ostberg, Carla M. Conway, Amari Dolan-Caret, Marshal S. Hoy, Kevin P. Feltz, and Kathy R. Echols

Open-File Report 2015-1217

U.S. Department of the Interior

U.S. Geological Survey 


\section{U.S. Department of the Interior \\ SALLY JEWELL, Secretary}

\section{U.S. Geological Survey \\ Suzette M. Kimball, Acting Director}

U.S. Geological Survey, Reston, Virginia: 2015

For more information on the USGS—-the Federal source for science about the Earth, its natural and living resources, natural hazards, and the environment-visit http://www.usgs.gov/ or call 1-888-ASK-USGS (1-888-275-8747).

For an overview of USGS information products, including maps, imagery, and publications, visit http://www.usgs.gov/pubprod/.

To order USGS information products, visit http://store.usgs.gov/.

Any use of trade, firm, or product names is for descriptive purposes only and does not imply endorsement by the U.S. Government.

Although this information product, for the most part, is in the public domain, it also may contain copyrighted materials as noted in the text. Permission to reproduce copyrighted items must be secured from the copyright owner.

Suggested citation:

Burdick, S.M., Elliott, D.G., Ostberg, C.O., Conway, C.M., Dolan-Caret, A., Hoy, M.S., Feltz, K.P., and Echols, K.R., 2015, Health and condition of endangered juvenile Lost River and shortnose suckers relative to water quality and fish assemblages in Upper Klamath Lake, Oregon, and Clear Lake Reservoir, California: U.S. Geological Survey Open-File Report 2015-1217, 56 p., http://dx.doi.org/10.3133/ofr20151217.

ISSN 2331-1258 (online) 


\section{Contents}

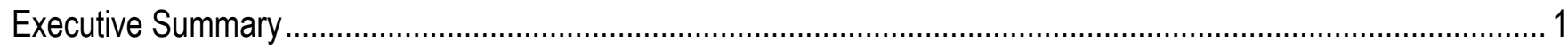

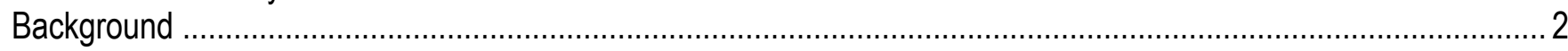

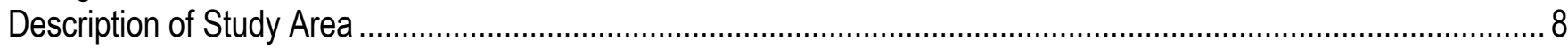

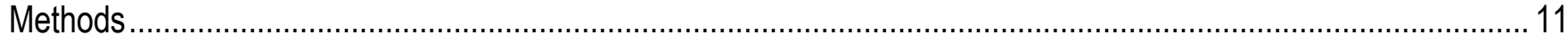

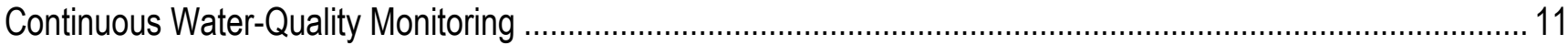

Ammonia and Microcystin Sampling and Analysis ................................................................................. 11

Fish Capture and Processing .............................................................................................................. 13

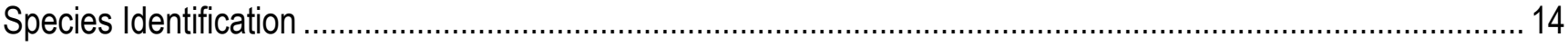

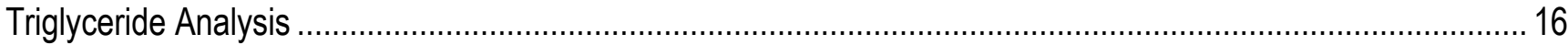

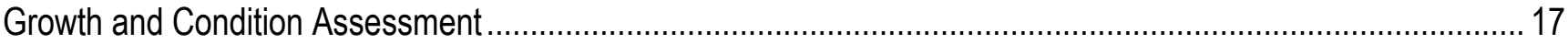

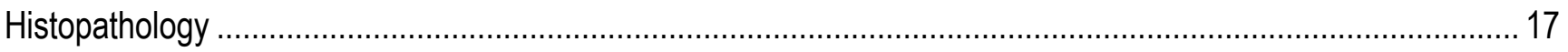

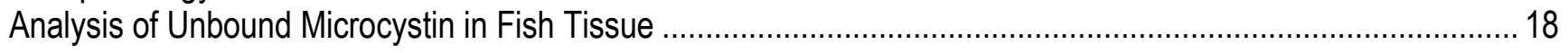

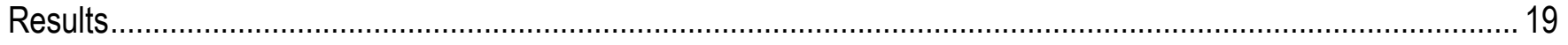

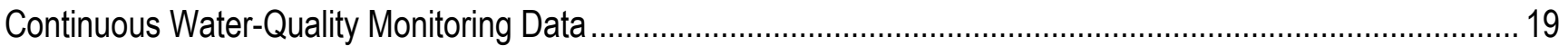

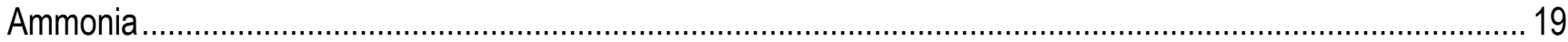

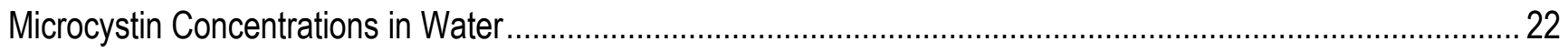

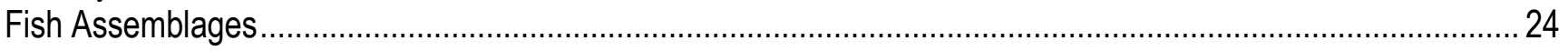

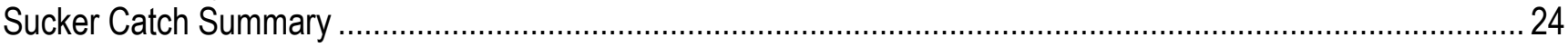

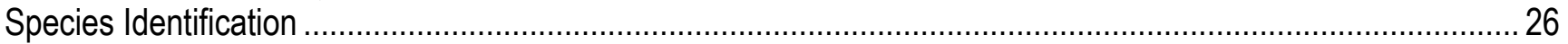

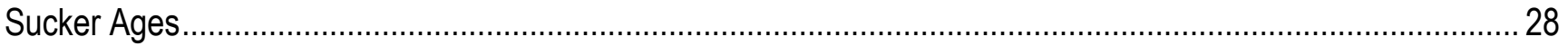

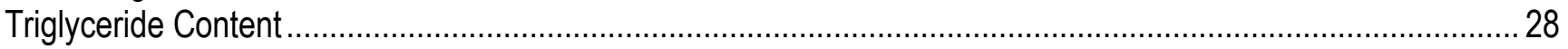

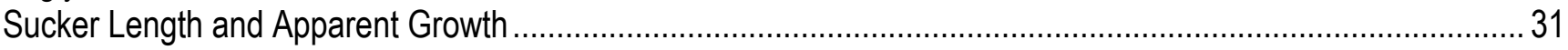

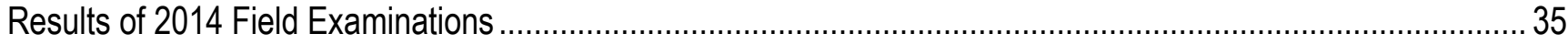

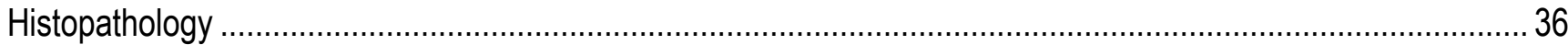

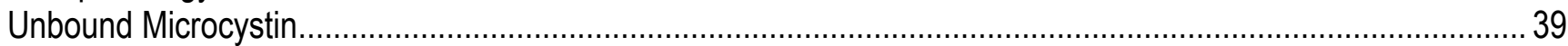

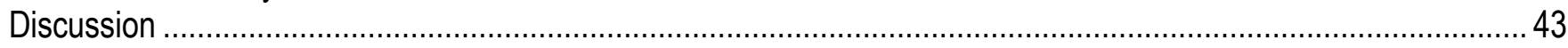

Survival and Apparent Growth of Lost River and Shortnose Suckers ……………………….................... 43

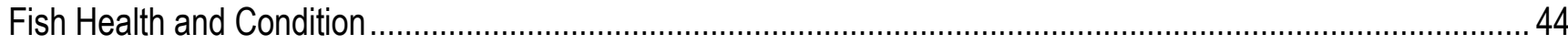

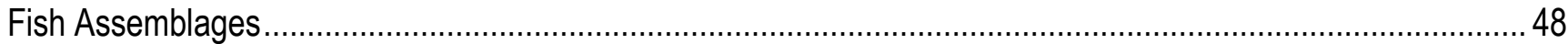

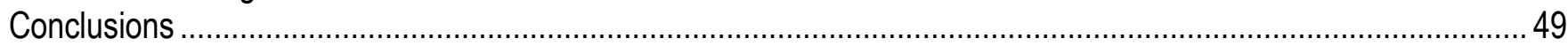

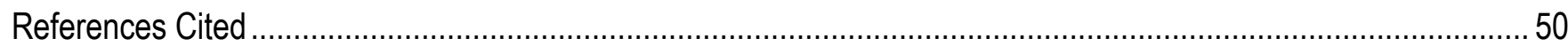

\section{Figures}

Figure 1. Map of Upper Klamath Lake, Oregon ..................................................................................

Figure 2. Map of Clear Lake Reservoir (Clear Lake), California..................................................................... 10

Figure 3. Dissolved-oxygen concentrations in Clear Lake Reservoir (U.S. Geological Survey site number 415007121102001), California, and at the lower mid-north site (U.S. Geological Survey site number 422622122004000) in Upper Klamath Lake, Oregon, during sucker sampling periods, 2013-14 
Figure 4. Values of pH in Clear Lake Reservoir (U.S. Geological Survey site number 415007121102001), California, and at the lower mid-north site (U.S. Geological Survey site number 422622122004000) in Upper Klamath Lake, Oregon, during sucker sampling periods, 2013-14....

Figure 5. Water temperature (in degrees Celsius) in Clear Lake Reservoir (U.S. Geological Survey site number 415007121102001), California, and at the lower mid-north site (U.S. Geological Survey site number 422622122004000) in Upper Klamath Lake, Oregon, during sucker sampling periods, 2013-2014

Figure 6. Un-ionized ammonia concentrations at Fish Banks and lower mid-north (U.S. Geological Survey site number 422622122004000) sites in Upper Klamath Lake, Oregon, and in Clear Lake Reservoir, California (U.S. Geological Survey site number 415007121102001), during sucker sampling seasons, 2013-14 .....

Figure 7. Concentrations of microcystin at Fish Banks and lower mid-north (U.S. Geological Survey site number 422622122004000) sites in Upper Klamath Lake, Oregon, during sucker sampling seasons, 2014......... 23 Figure 8. Catch rates and timing of age-0 sucker captures along Fish Banks in Upper Klamath Lake, Oregon, 2013-14.

Figure 9. Catch rates and timing of sucker captures (ages combined) in Clear Lake Reservoir, California, 2013-14.....

Figure 10. Probability of genetic assignment as Lost River sucker by individual fish collected in Upper Klamath Lake, Oregon, and Clear Lake Reservoir, California

Figure 11. The proportion of annual sucker catches with zero to six annuli on fin rays in Upper Klamath Lake, Oregon, and Clear Lake Reservoir, California, 2012-14.

Figure 12. Milligrams of triglyceride content per grams of body weight (mg TG/g Body Weight) by age of suckers collected from Clear Lake Reservoir, California, 2014.

Figure 13. Standard length of suckers $(\mathrm{mm})$ by age and cohort, from data collected from Clear Lake Reservoir, California, 2010-2013 32

Figure 14. Standard length distribution for age-0 suckers captured in Clear Lake Reservoir, California, 2012-13, and in Upper Klamath Lake, Oregon, 2013-14.

Figure 15. Genetic probability of species assignment as a Lost River sucker (Prob[Lost River Sucker]) by standard length and week, for suckers collected from Upper Klamath Lake, Oregon, 2014 34

Figure 16. Inflammatory cell infiltration surrounding a bile duct (peribiliary cuffing) in the liver of a sucker sampled from Upper Klamath Lake, Oregon.

\section{Tables}

Table 1. The 18 nuclear deoxyribonucleic acid (DNA) TaqMan ${ }^{\circledR}$ assays and one mitochondrial DNA (mtDNA) .... 15

Table 2. Fulton's condition factor by sucker species, lake, and year.

Table 3. Number of fish positive by histopathological examination for liver inflammation, hepatocyte cytoplasmic vacuolation, and cytoplasmic glycogen staining among suckers sampled from Clear Lake Reservoir, California, and Upper Klamath Lake, Oregon, during 2013, and 2014

Table 4. Number of fish positive by histopathological examination of gill samples for inflammation, necrosis, hyperplasia, hypertrophy, and trichodinid protozoan parasites among suckers sampled from Clear Lake Reservoir, California, and Upper Klamath Lake, Oregon, during 2013, and 2014

Table 5. Occurrence of histological response and host response to parasites observed microscopically in suckers sampled from Clear Lake Reservoir, California, and Upper Klamath Lake, Oregon, 2014 


\section{Conversion Factors}

SI to Inch/Pound

\begin{tabular}{|c|c|c|}
\hline Multiply & By & To obtain \\
\hline \multicolumn{3}{|c|}{ Length } \\
\hline nanometer (nm) & $3.93701 \times 10^{-8}$ & inch (in.) \\
\hline micrometer $(\mu \mathrm{m})$ & 0.000039 & inch (in.) \\
\hline millimeter $(\mathrm{mm})$ & 0.03937 & inch (in.) \\
\hline centimeter $(\mathrm{cm})$ & 0.3937 & inch (in.) \\
\hline meter $(\mathrm{m})$ & 3.281 & foot $(\mathrm{ft})$ \\
\hline meter $(\mathrm{m})$ & 1.094 & yard (yd) \\
\hline kilometer $(\mathrm{km})$ & 0.6214 & mile (mi) \\
\hline kilometer $(\mathrm{km})$ & 0.5400 & mile, nautical (nmi) \\
\hline \multicolumn{3}{|c|}{ Area } \\
\hline hectare (ha) & 2.471 & acre \\
\hline square hectometer $\left(\mathrm{hm}^{2}\right)$ & 2.471 & acre \\
\hline hectare (ha) & 0.003861 & square mile $\left(\mathrm{mi}^{2}\right)$ \\
\hline square kilometer $\left(\mathrm{km}^{2}\right)$ & 2.471 & acre \\
\hline square kilometer $\left(\mathrm{km}^{2}\right)$ & 0.3861 & square mile $\left(\mathrm{mi}^{2}\right)$ \\
\hline \multicolumn{3}{|c|}{ Volume } \\
\hline microliter $(\mu \mathrm{L})$ & $3.381 \times 10^{-5}$ & ounce, fluid (fl. oz) \\
\hline milliliter $(\mathrm{mL})$ & 0.0338 & ounce, fluid (fl. oz) \\
\hline liter $(\mathrm{L})$ & 33.81 & ounce, fluid (fl. oz) \\
\hline \multicolumn{3}{|c|}{ Mass } \\
\hline $\operatorname{gram}(\mathrm{g})$ & 0.03527 & ounce, avoirdupois (oz) \\
\hline milligram (mg) & $3.5274 \times 10^{-5}$ & ounce, avoirdupois (oz) \\
\hline microgram $(\mu \mathrm{g})$ & $3.5274 \times 10^{-8}$ & ounce, avoirdupois (oz) \\
\hline nanogram (ng) & $3.53 \times 10^{-11}$ & ounce, avoirdupois (oz) \\
\hline
\end{tabular}

Temperature in degrees Celsius $\left({ }^{\circ} \mathrm{C}\right)$ may be converted to degrees Fahrenheit $\left({ }^{\circ} \mathrm{F}\right)$ as follows:

${ }^{\circ} \mathrm{F}=\left(1.8 \mathrm{x}^{\circ} \mathrm{C}\right)+32$

Concentrations of chemical constituents in water are given either in milligrams per liter $(\mathrm{mg} / \mathrm{L})$ or in micrograms per liter $(\mu \mathrm{g} / \mathrm{L})$.

Datum

Horizontal coordinate information is referenced to North American Datum of 1983 (NAD 83). 


\section{Abbreviations and Acronyms}

\begin{tabular}{ll}
\hline \multicolumn{1}{c}{ Abbreviation or Acronym } & \multicolumn{1}{c}{ Meaning } \\
\hline a & estimated length-weight power curve constant \\
AFA & Aphanizomenon flos-aquae \\
b & estimated exponent of the length-weight power curve \\
DNA & deoxyribonucleic acid \\
DO & dissolved oxygen \\
HDPE & high-density polyethylene \\
HPLC & high-performance liquid chromatography \\
K & number of population clusters \\
MCLRa & Microcystin LR \\
MCMC & Markov chain Monte Carlo (simulation) \\
mtDNA & mitochondrial deoxyribonucleic acid \\
NH & ammonia \\
PAS & periodic acid-Schiff \\
PP2A & protein phosphatase 2A \\
Prob [LRS] & probability of species being a Lost River sucker based \\
$R^{2}$ & on genetic data from 18 markers \\
SL & coefficient of determination \\
SNPs & standard length \\
TFA & single nucleotide polymorphisms \\
USGS & trifluoracetic acid \\
W $_{\mathrm{r}}$ & U.S. Geological Survey \\
\hline & relative weight \\
\hline &
\end{tabular}




\section{Health and Condition of Endangered Juvenile Lost River and Shortnose Suckers Relative to Water Quality and Fish Assemblages in Upper Klamath Lake, Oregon, and Clear Lake Reservoir, Californiaa}

By Summer M. Burdick, Diane G. Elliott, Carl O. Ostberg, Carla M. Conway, Amari Dolan-Caret, Marshal S. Hoy, Kevin P. Feltz, and Kathy R. Echols

\section{Executive Summary}

Most mortality of endangered Lost River (Deltistes luxatus) and shortnose (Chasmistes brevirostris) suckers in Upper Klamath Lake, Oregon, appears to occur within the first year of life. However, juvenile suckers in Clear Lake Reservoir, California, appear to survive longer and may even recruit to the spawning populations. Our goal in this study was to develop productive lines of inquiry into the causes of mortality of juvenile suckers, especially in Upper Klamath Lake, through comparison of sucker health and environmental conditions in both lakes. The health of juvenile suckers was associated with physical, biological, and chemical characteristics in each lake from July to September 2013 and 2014.

Water-quality dynamics differed substantially between lakes. Diel fluctuations were greater for dissolved-oxygen concentrations and $\mathrm{pH}$ in Upper Klamath Lake than in Clear Lake Reservoir, but diel temperature fluctuations were greater in Clear Lake Reservoir. Minimum dissolved-oxygen concentrations were as low as 1.0 milligram per liter $(\mathrm{mg} / \mathrm{L})$ in Upper Klamath Lake, but were no lower than $5.7 \mathrm{mg} / \mathrm{L}$ in Clear Lake Reservoir. Un-ionized ammonia $\left(\mathrm{NH}_{3}\right)$ concentrations were near or less than the minimum reporting limit of $0.002 \mathrm{mg} / \mathrm{L} \mathrm{NH}_{3}$ in Clear Lake Reservoir and generally were less than the concentration known to cause cellular changes to the gills or mortality of suckers in Upper Klamath Lake. Concentrations of microcystins were less than the detection limit $(\leq 0.10$ microgram per liter $[\mu \mathrm{g} / \mathrm{L}])$ in both dissolved $(<63$ micrometers $[\mu \mathrm{m}])$ and particulate $(\geq 63 \mu \mathrm{m})$ fractions of water samples collected from Clear Lake Reservoir in both years. In Upper Klamath Lake, concentrations of microcystins were relatively low in the 2013 particulate fractions and dissolved fractions of samples in both years, but as high as $44.30 \mu \mathrm{g} / \mathrm{L}$, more than 44 times the World Health Organization recommended levels for drinking water $(1 \mu \mathrm{g} / \mathrm{L})$, in the 2014 particulate fraction. However, there was little histological evidence and no chemical evidence that these concentrations in water were harmful to suckers that we captured. 
The species and age compositions of juvenile sucker populations differed between lakes. A total of 98 percent of all juvenile suckers captured in Upper Klamath Lake were age-0. In contrast, as many as six age classes of suckers were represented in Clear Lake Reservoir, indicating much better juvenile survival than in Upper Klamath Lake. Based on genetic species identification, 98 percent of juvenile suckers collected from Clear Lake Reservoir were shortnose or Klamath largescale suckers (Catostomus snyderi). In contrast, there was a high degree of apparent genetic hybridization in juvenile suckers collected from Upper Klamath Lake, and both Lost River and non-Lost River juvenile suckers were nearly equally represented in samples.

Neither gross nor histological examination revealed a high prevalence of abnormalities in suckers that might indicate a mechanism for juvenile mortality in Upper Klamath Lake. Therefore, high mortality primarily may have occurred outside our study period (for example, in spring or over winter), or was owing to a factor that could not be detected with our methods (for example, predation).

Alternatively, abnormalities in a small percentage of passively captured suckers in Upper Klamath Lake may indicate health-related issues that were more prevalent in populations than in our samples. Some apparent symptoms of stress or exposure to irritants, such as peribiliary cuffing in hepatocytes and mild inflammation and necrosis in gill tissues, were present in suckers from both lakes and do not appear to be clues to the cause of differential mortality between lakes. Seasonal trends in energy storage as glycogen and triglycerides were similar between lakes, indicating prey availability was not a factor in differential mortality.

Differences in sucker health and condition between lakes were considered the most promising clues to the causes of differential juvenile sucker morality between lakes. A low prevalence of petechial hemorrhaging of the skin (16 percent) and deformed opercula (8 percent) in Upper Klamath Lake suckers may indicate exposure to a toxin other than microcystin. Suckers grew slower in their first year of life, but had similar or greater triglyceride and glycogen levels in Upper Klamath Lake compared to Clear Lake Reservoir. These findings do not suggest a lack of prey quantity but may indicate lower prey quality in Upper Klamath Lake.

\section{Background}

Lost River (Deltistes luxatus) and shortnose suckers (Chasmistes brevirostris) were once abundant throughout the Upper Klamath Basin, but populations of both species notably decreased by the 1960s and were listed as endangered in 1988 (U.S. Fish and Wildlife Service, 1988). These fish were once so numerous they were considered an important food source for the Native American Tribes and supported a commercial cannery on the Lost River (National Research Council, 2004). The largest extant populations of Lost River suckers occur in Upper Klamath Lake, Oregon, whereas the largest extant population of shortnose suckers probably occurs in Clear Lake Reservoir, California. Although a ban on fishing for suckers in 1987 may have improved adult survival, the populations did not rebound (Markle and Cooperman, 2002; National Research Council, 2004). In fact, sucker populations in Upper Klamath Lake continue to decrease, and there are probably one-tenth as many suckers today as there were a decade ago (Hewitt and others, 2014). 
Upper Klamath Lake sucker populations are decreasing because mortality is not being balanced by recruitment. Cohorts produced in the early 1990s now make up the largest proportion of adult sucker populations living in Upper Klamath Lake in 2014. About 5-10 percent of adult Lost River suckers die each year, but there has not been measurable recruitment since the cohorts produced in the early 1990s joined spawning aggregations (Hewitt and others, 2014). About 5-20 percent of adult shortnose suckers die each year. Mark-recapture analysis indicates that a small number of new recruits have joined the spawning aggregations of adult shortnose suckers since 2008. However, shortnose suckers first detected in the spawning aggregations since 2008 are not as small as new recruits detected in the late 1990s, making recent recruitment estimates for this species suspect (Hewitt and others, 2014).

Recruitment to spawning aggregations in Upper Klamath Lake likely is limited by mortality in the juvenile life stage. Both Lost River and shortnose suckers spawn in the Williamson and Sprague Rivers each spring. Lost River suckers also aggregate to spawn along the eastern shoreline of Upper Klamath Lake each year between March and June (Burdick and others, 2015). Larvae of both species were captured drifting downstream in the Williamson and Sprague Rivers each year between 2004 and 2010, indicating that spawning and hatching of eggs were both successful (Martin and others, 2013). Most larval suckers drifting in these rivers reach Upper Klamath Lake, where they can feed freely and food is abundant, within a day after they emerge from the gravel (Cooperman and Markle, 2003). Age-0 juvenile suckers are then captured throughout Upper Klamath Lake until late August or early September, when catches rapidly decrease in most years (Bottcher and Burdick, 2010). Despite intensive sampling throughout Upper Klamath Lake, in the lower reaches of the lake's tributaries, and at the outlet of the lake, age-1 endangered sucker captures are uncommon and older juveniles rarely are encountered in Upper Klamath Lake (Bottcher and Burdick, 2010).

Juvenile suckers in Upper Klamath Lake appear mostly healthy until they disappear from catches, but health cannot be adequately assessed without reference to a surviving population of juvenile suckers of the same species. Juvenile suckers in Upper Klamath Lake grow rapidly throughout August and September each year, but growth slows in October (Bottcher and Burdick, 2010; Burdick and Brown, 2010). These fish also accumulate triglycerides throughout the summer, indicating prey is sufficient to provide energy storage (Foott and others, 2012). Skeletal deformities usually occur in less than 10 percent of age-0 Lost River and shortnose suckers collected annually from Upper Klamath Lake, but have been reported in as many as 27 percent in some years (Burdick and others, 2009). The most commonly reported deformity is shortened opercula, but scoliosis and fused vertebrae also are observed in less than 1 percent of individuals (Burdick and Hewitt, 2012). Wild-caught and mesocosmheld juvenile suckers from Upper Klamath Lake rarely are diseased and histological abnormalities are uncommon and usually minor (Foott and others, 2012, 2014).

Juvenile suckers in Upper Klamath Lake are host to numerous parasites, but it is unclear if any of these parasites substantially contribute to juvenile sucker mortality. Because of low prevalence (for example, Epistylus sp. and Diplostomum sp.) or lack of pathological response related to parasite infestation (for example, Trichodina ciliatesis, Myxobolus sp., Parvicapsula sp.), most of the identified parasites are likely to be benign (Foott and Stone, 2005; Simon and others, 2013; Kent and others, 2014). Notably, Parvicapsula minibicornis is known to have deleterious effects on the survival of juvenile salmonids (Kent and others, 1997), but no pathological effects were associated with the presence of a Parvicapsula species in suckers from Upper Klamath Lake (Foott and others, 2005; Kent and others, 2014). Three parasites that are prevalent, associated with pathology in juvenile suckers, or 
both, include the trematodes Bolbophorus sp. and Ichthyocotylurus sp., and the nematode Contracaecum sp. Numerous facultative bacterial pathogens have been isolated from asymptomatic juvenile suckers (Foott and others, 2013). Among the bacterial genera detected by molecular methods in juvenile sucker mucus were genera such as Aeromonas, Pseudomonas, Vibrio, and Flavobacterium, which include fish pathogenic species (Burdick and others, 2009). The myxosporean parasite Myxobolus sp. also was identified in the kidneys of about 15 percent of juvenile suckers held as sentinels in Upper Klamath Lake, but was not associated with inflammation or other signs of disease or distress (Foott and others, 2012).

In contrast with Upper Klamath Lake populations, juvenile suckers appear to survive longer in Clear Lake Reservoir, California. In a 2012 study conducted in Clear Lake Reservoir, 83 percent of juvenile suckers had standard lengths (SLs) of 72-285 mm and were ages 1-6, with the remainder being age-0, indicating that these fish survived longer than is typical in Upper Klamath Lake (Burdick and Rasmussen, 2013). In most but not all years, small (300-400 mm fork length) Lost River suckers are well represented in trammel net samples from Clear Lake Reservoir, indicating intermittent but not infrequent recruitment to the spawning population (Hewitt and Hayes, 2013). Lengths for adult shortnose suckers captured in trammel nets are more or less normally distributed, with mean annual lengths remaining about the same each year. This indicates fairly consistent recruitment for this species in Clear Lake Reservoir (Hewitt and Hayes, 2013). However, there is a lack of information on the health, growth, and condition of juvenile suckers in Clear Lake Reservoir.

Investigation of physical, biological, chemical, or other characteristics that differ between Upper Klamath Lake and Clear Lake Reservoir may lead to testable hypotheses to explain the differences in apparent juvenile sucker mortality. Although both lakes are shallow pools located in a volcanic semiarid landscape, the surrounding habitat and land use vary. Upper Klamath Lake has emergent vegetation marshes along large parts of its northern shoreline that may provide cover for young suckers. Shoreline vegetation is scant at Clear Lake Reservoir, but emergent vegetation can be thick when lake depth is less than about $1 \mathrm{~m}$. Dominant primary production in Upper Klamath Lake switched from diatoms to cyanobacteria with increased phosphorus loading in the early 20th century following reclamation of littoral wetlands for agricultural use (Bradbury and others, 2004). Although the Clear Lake Reservoir basin is almost entirely publicly owned, moderate to heavy cattle grazing occurs in both basins. During prolonged periods each summer, the algal community in Upper Klamath Lake is a near monoculture of Aphanizomenon flos-aquae (AFA; Eldridge and others, 2012a). The biovolume of primary producers in Clear Lake Reservoir is dominated by diatoms from April to June and in November, and is codominated by diatoms and green algae from July to October (PhycoTech, 2012). Cyanobacterial blooms in Clear Lake Reservoir are limited in distribution and small compared to those observed in Upper Klamath Lake (PhycoTech, 2012). Wind agitates the substrate in Clear Lake Reservoir, causing turbid water. Upper Klamath Lake is hypereutrophic and is a host to numerous non-native fishes that may compete with or prey upon suckers. Clear Lake Reservoir appears less productive than Upper Klamath Lake (PhycoTech, 2012). Only two of the non-native species in Upper Klamath Lake are also in Clear Lake (fathead minnows and brown bullheads, Pimephales promelas Rafinesque and Ameiurus nebulosus, respectively), and Clear Lake Reservoir is a host to one species of non-native fish not found in Upper Klamath Lake (Sacramento perch, Archoplites interruptus) (Koch and others, 1975). 
Water quality in Upper Klamath Lake is strongly correlated with the bloom dynamics of the cyanobacterium AFA (Eldridge and others, 2012b). One or two massive blooms of AFA occur every year in Upper Klamath Lake between May and October (Eldridge and others, 2012b). The first annual bloom starts with the increase in water temperature in May or June and ends with a period of AFA senescence known as the "bloom crash" in July or early August in most years. The second bloom, if it occurs, frequently is less intense than the first bloom, and water quality does not reach the same extremes during the second bloom crash. Peak blooms are correlated with high $\mathrm{pH}(>9.5)$ and dramatic swings in dissolved-oxygen (DO) concentrations. Although dissolved total nitrogen concentrations generally are lower during heavy bloom periods, the elevated $\mathrm{pH}$ increases the potential toxicity of ammonia in the lake because ammonia-nitrogen $\left(\mathrm{NH}_{3}-\mathrm{N}\right)$ shifts toward the more toxic un-ionized form $\left(\mathrm{NH}_{3}\right)$ when $\mathrm{pH}$ is high and toward the less toxic ionized form $\left(\mathrm{NH}_{4}{ }^{+}\right)$when $\mathrm{pH}$ is low (Wedemeyer and others, 1976). During "bloom crash" periods, DO concentrations can be hypoxic $(<4 \mathrm{mg} / \mathrm{L}), \mathrm{pH}$ stabilizes at around 7, and un-ionized ammonia can remain high $\left(>0.5 \mathrm{mg} / \mathrm{L}\right.$ as $\mathrm{NH}_{3}$; Eldridge and others, 2012a). Microcystin, a powerful hepatotoxin produced by the cyanobacterium Microcystis aeruginosa, also increases during the bloom crash, with concentrations peaking as high as $17 \mu \mathrm{g} / \mathrm{L}$ in 2007 (Eldridge and others, 2012b, 2013). Each of these water-quality variables may independently affect the survival of juvenile suckers, or combinations of multiple variables near the thresholds of sucker tolerance may cause direct mortality.

Hypoxic conditions may directly or indirectly cause juvenile sucker mortality in Upper Klamath Lake. During bloom crash periods, DO concentrations within $1 \mathrm{~m}$ of the substrate in Upper Klamath Lake commonly decrease to less than $2 \mathrm{mg} / \mathrm{L}$ for several hours to as long as a day (http://nwis.waterdata.usgs.gov/nwis/qwdata). On occasion, DO concentrations near the lake bottom decrease to less than $1 \mathrm{mg} / \mathrm{L}$ for short periods of time ranging from 1 to as long as 16 hours (http://nwis.waterdata.usgs.gov/nwis/qwdata). Mean median 24-96-hour lethal DO concentrations $\left(\mathrm{LC}_{50} \mathrm{~s}\right)$ range from 1.14 to $1.34 \mathrm{mg} / \mathrm{L}$ for juvenile shortnose suckers, and from 1.58 to $1.62 \mathrm{mg} / \mathrm{L}$ for juvenile Lost River suckers (Saiki and others, 1999). In 14-day trials, the mortality of Lost River suckers increased as DO concentrations decreased from 2.1 to $1.4 \mathrm{mg} / \mathrm{L}$ (Meyer and Hansen, 2002). DO concentrations are rarely less than $2 \mathrm{mg} / \mathrm{L}$ for more than 24 hours, but shortnose suckers can not tolerate DO concentrations of less than $0.7 \mathrm{mg} / \mathrm{L}$ for even 1 minute (Castleberry and Cech, 1993). Although there are no observable adverse physiological effects to Lost River suckers exposed to DO concentrations at $2.10 \mathrm{mg} / \mathrm{L}$ or greater for 14 days (Meyer and Hansen, 2002), suckers may exhibit a behavioral response to low DO. Although other fishes exposed to very low DO concentration are known to cease feeding and become lethargic (Svobodova and others, 1993), juvenile suckers have been observed to leave their normally occupied benthic habitats and swim near the surface (Saiki and others, 1999). When allowed access to the surface, Lost River suckers were able to survive several hours in completely anoxic water by gulping air (Foott and others, 2007). This behavior may make suckers temporarily more susceptible to predation by surface-feeding birds. 
High $\mathrm{pH}$ in Upper Klamath Lake that commonly exceeds 9.75 and occasionally reaches 10.50 also has potential to affect juvenile sucker mortality. In laboratory trials, juvenile Lost River suckers did not begin to express signs of $\mathrm{pH}$-related stress until $\mathrm{pH}$ was greater than or equal to 10.00 (Meyer and Hansen, 2002). When $\mathrm{pH}$ was greater than 10.00, juvenile suckers convulsed, swam erratically, produced excessive mucus, and exhibited hemorrhaging from the gills and eyes (Saiki and others, 1999). The 96-hour median lethal $\mathrm{pH}$ for larval juvenile Lost River and shortnose suckers is estimated to be at least 10.30 (Saiki and others, 1999). Falter and Cech (1991) reported that hatchery-reared juvenile shortnose suckers exposed to rapidly increasing $\mathrm{pH}$ had a mean acute tolerance of only 9.55 (with death occurring within 1 minute of exposure), but water temperatures were $4-8{ }^{\circ} \mathrm{C}$ cooler than those used by Saiki and others (1999) and cooler than normal summertime water temperatures in Upper Klamath Lake.

Un-ionized ammonia concentrations in Upper Klamath Lake commonly are high enough to affect suckers and in some years exceed the median lethal thresholds for shortnose suckers. Gill lamellar thickness increases at concentrations of un-ionized ammonia of $0.20 \mathrm{mg} / \mathrm{L}$ and higher (Lease and others, 2003). Hyaline droplets in the proximal convoluted tubules of the kidneys (indicative of excess protein from the filtrate) were associated with experimental exposure of Lost River suckers to high un-ionized ammonia concentrations $(0.44 \mathrm{mg} / \mathrm{L}$; Foott and others, 2000$)$, although the pathological significance of this finding is unknown (Ferguson 1989; Wolf and others, 2015). Foott and others (2014) speculated that increased urine output, stimulated by elevated ammonia, may result in the kidney tubule changes. Liver, pancreatic, and intestinal damage have not been associated with high concentrations of unionized ammonia (Foott and others, 2000). The 48-hour median lethal concentration ( $\left.\mathrm{LC}_{50}\right)$ for unionized ammonia was determined to be $0.48 \mathrm{mg} / \mathrm{L}$ for shortnose suckers and $0.92 \mathrm{mg} / \mathrm{L}$ for Lost River suckers in laboratory experiments (Saiki and others, 1999). Un-ionized ammonia concentrations exceeded $0.48 \mathrm{mg} / \mathrm{L}$ in 2 percent or fewer samples between May and September each year from 1990 to 1995 and from 2004 to 2010. In comparison, un-ionized ammonia exceeded $0.48 \mathrm{mg} / \mathrm{L}$ in $7-35$ percent of samples each year from 1996 to 2003 (Klamath Tribes, unpub. data, 2003).

Microcystin in Upper Klamath Lake could cause severe damage to the liver and other tissues of juvenile suckers that may result in mortality. In Upper Klamath Lake the extremely toxic microcystinLR congener primarily is produced by Microcystis aeruginosa during the period when AFA senesces (Carmichael and others, 2000; Eldridge and others, 2012b). The primary route of exposure to microcystins for fish is through their food and to a lesser extent the toxins also may be taken up in gills when there are high concentrations of dissolved microcystins in the water column (Carbis and others, 1996). Tolerance of microcystins varies among fishes and has not been established specifically for Lost River or shortnose suckers (Fischer and Dietrich, 2000). The most relevant study on lethal concentrations is that of Fischer and Dietrich (2000), who determined that a cyprinid, common carp (Cyprinus carpio), died within 10 hours when gavaged with $6.6 \mu \mathrm{g} / \mathrm{g}$ body weight and within 24-48 hours when gavaged with $1.7 \mu \mathrm{g} / \mathrm{g}$ body weight microcystin-LR. 
Because juvenile suckers consume benthic material during feeding (Markle and Clauson, 2006), they may be exposed to Microcystis cells deposited in the sediment. Alternatively, they may be exposed to the toxin through the food chain, given that prey, such as chironomids, consume M. aeruginosa cells (B.H. Rosen, U.S. Geological Survey, unpub. data, 2008). Peak concentrations can be greater than 10 $\mu \mathrm{g} / \mathrm{L}$ in the water column, but vary substantially among years. The highest microcystin concentrations generally occur in colonies of cells $(>63 \mu \mathrm{m})$, rather than in single independent cells $(1.5-63 \mu \mathrm{m})$ or the dissolved (extra-cellular) part of water samples from Upper Klamath Lake, although concentrations also may be elevated in the dissolved fraction. Microcystin concentrations in the sediment commonly are as high as $38.2 \mu \mathrm{g} / \mathrm{g}$ dry weight (Eldridge and others, 2013). The hypothesis that suckers are exposed to microcystin through the food chain is supported by positive immunohistochemical staining for microcystin toxin (MCLRa) in digesta and intestinal epithelium of juvenile sentinel suckers held in cages or net pens in Upper Klamath Lake during the summers of 2011, 2012, and 2013 (Foott and others, 2014). Apparent suppression of protein phosphatase 2A (PP2A), an enzyme responsive to microcystin toxin, observed in a small sample of age-0 Lost River suckers caged in Upper Klamath Lake during the summer of 2013, also is consistent with microcystin exposure (Foott and others, 2014). However, liver damage observed in caged fish has been minor, and positive immunohistochemical staining was not associated with focal necrosis in hepatocytes of sentinel age-0 Lost River suckers (Foott and others, 2013). Therefore, microcystin concentrations may not be high enough, last long enough, be metabolized fast enough, or be composed of a large enough portions of the most toxic variants to be a major factor in juvenile sucker mortality.

To identify factors that may be responsible for higher juvenile sucker mortality in Upper Klamath Lake compared to Clear Lake Reservoir, we examined sucker age, length, and health, and water chemistry. Previous studies on juvenile sucker health were limited by a lack of a comparison group. There are no populations of Lost River or shortnose suckers unexposed to poor water quality, parasites, or toxins that could be used as a control group. Therefore, because suckers in Clear Lake Reservoir appear to survive longer than those in Upper Klamath Lake, we used Clear Lake Reservoir populations and hatchery-raised suckers as our reference groups. We used an observational approach to develop ecologically reasonable and testable hypotheses that can be examined in detail with future experimental research. 


\section{Description of Study Area}

Major land-use changes in the Upper Klamath Lake watershed have shaped the landscape and its aquatic environments. Landscape changes occurred after the city of Klamath Falls, located at the southern terminus of the lake, was settled in 1867. Overgrazing by cattle was identified as an ecological concern in the Upper Klamath Basin as early as 1883 (National Research Council, 2004). Diking and draining wetlands in the first one-half of the 20th century resulted in a loss of more than 20,000 acres of littoral wetlands surrounding Upper Klamath Lake, although about one-half of these wetlands have since been reinundated (National Research Council, 2004). The loss of wetland habitat and overgrazing most likely contributed to nutrient loading and massive annual blooms of the blue-green cyanobacterium AFA in Upper Klamath Lake (National Research Council, 2004). Shoreline habitat also was altered in 1909 when large boulders were used to stabilize the eastern shore of the lake for the construction of the Southern Pacific Railroad (National Research Council, 2004). Present-day land use in the watershed primarily is hay farming and cattle ranching, but the headwaters are in the U.S. Forest Service's Fremont-Winema National Forest, and a substantial amount of the lakeshore is managed by public and private entities for fish, wildlife, and water storage.

Upper Klamath Lake is uniformly shallow, with an average water depth of about $2.6 \mathrm{~m}$ and a surface area of about $305 \mathrm{~km}^{2}$ at full pool (National Research Council, 2004). A 6.4-9.5-m-deep trench runs along the western shore of the lake. Most of the flow enters through the Williamson River on the eastern shore and the smaller Wood River (fig. 1). A small but notable amount of water also upwells through the volcanic soils along the lakeshore. The bottom of the lake is covered with fine organic detritus composed primarily of decaying diatoms and cyanobacteria. Shoreline wetlands in the northern part of the lake are heavily vegetated with wocus (Nuphar spp.), tules (Schoenoplectus acutus), and willows (Salix spp.). Spring-fed creeks enter the lake in the area of these wetlands and are associated with relatively good summertime water quality when compared to the rest of the lake (Banish and others, 2009).

Clear Lake Reservoir historically was a natural lake covering about 6,500 ha, with an associated marshy area and meadow to the east where the largest tributary (Willow Creek) entered (fig. 2). The Bureau of Reclamation built a dam on the Lost River near the lake outlet in 1910, which inundates the marsh in most years and essentially expanded the lake by about 3,900 ha (Buettner and Scoppettone, 1991). The lower reach of Willow Creek was channelized and redirected toward the dam at the outlet of the lake during dam construction. The two parts of the lake are presently connected by a wide shallow channel. Water depth in the western lobe of the lake can be as deep as $4 \mathrm{~m}$, but is less than $2 \mathrm{~m}$ deep in the eastern lobe at full pool. Clear Lake Reservoir is in the U.S. Fish and Wildlife Service's Clear Lake Reservoir National Wildlife Refuge, and the upper watershed is almost entirely located within the U.S. Forest Service's Modoc National Forest. The area around the lake is rocky with sagebrush (Artemesia spp.) steppe plant communities and western juniper (Juniperus occidentalis), whereas the upper watershed is a ponderosa pine (Pinus ponderosa) forest (Buettner and Scoppettone, 1991). The bottom of Clear Lake Reservoir is covered with claylike sediment and occasional large lava rocks. This lake is turbid, which is likely the result of wind coupled with shallow water. 


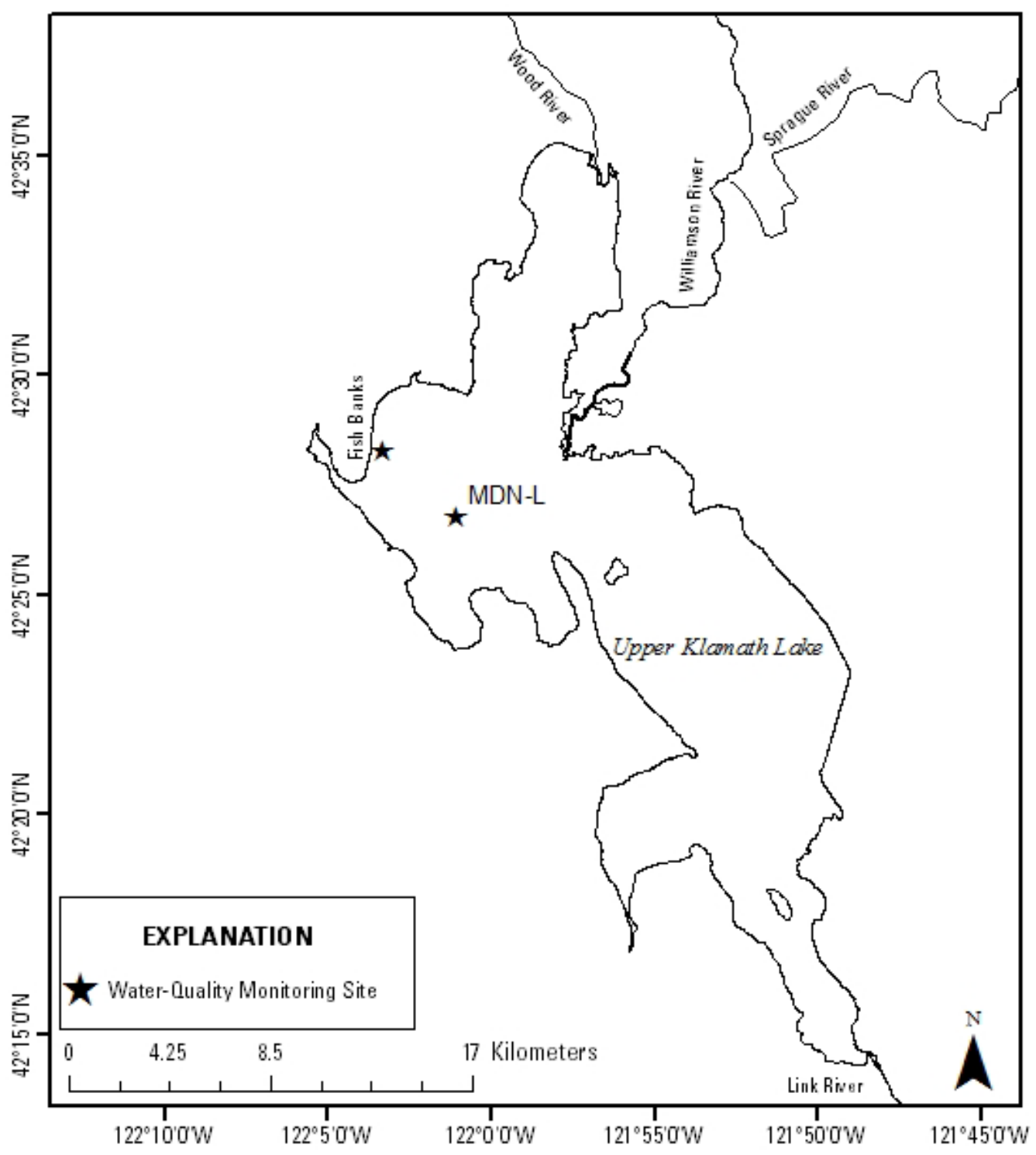

Figure 1. Map of Upper Klamath Lake, Oregon. Fish were sampled along Fish Banks on the northwestern lakeshore. Continuous water-quality measurements were collected at U.S. Geological Survey monitoring site number 422622122004000 (MDN-L) and at an additional site near Fish Banks. 


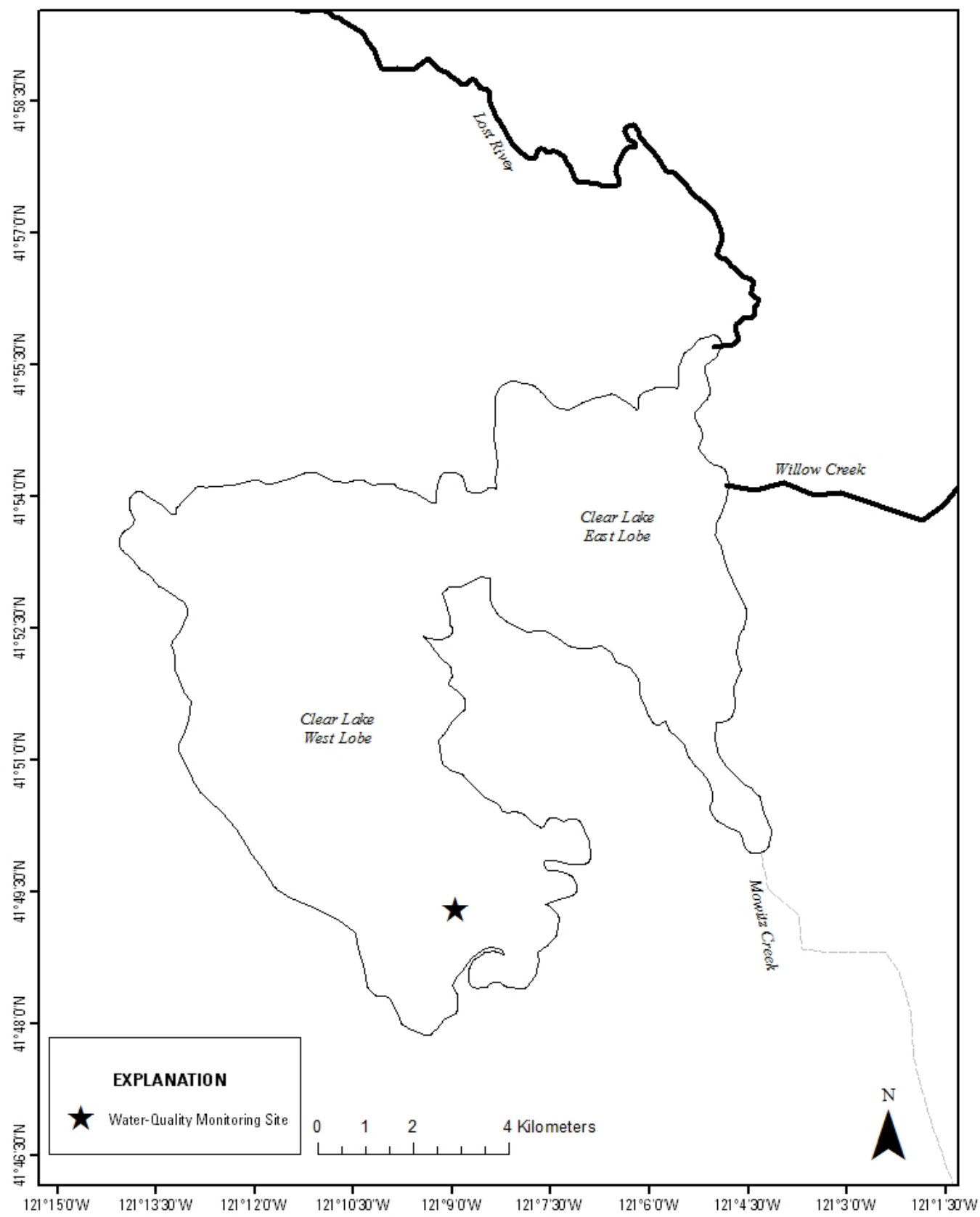

Figure 2. Map of Clear Lake Reservoir (Clear Lake), California. Fish were sampled along the southwestern shore. Continuous water-quality measurements were collected at U.S. Geological Survey monitoring site number 415007121102001, which is shown on the map. 


\section{Methods}

\section{Continuous Water-Quality Monitoring}

Continuous water-quality data for Upper Klamath Lake were obtained from the lower mid-north U.S. Geological Survey (USGS) site number 422622122004000 (http://nwis.waterdata.usgs.gov/nwis/qwdata). We queried hourly DO concentration, $\mathrm{pH}$, and water temperature data from the water-quality monitor located at this site, $1 \mathrm{~m}$ above the substrate. We maintained a second continuous water-quality meter in the southern end of the western lobe of Clear Lake Reservoir at USGS site number 415007121102001 near Newell, California (http://nwis.waterdata.usgs.gov/nwis/qwdata). At this site, DO concentrations and percent saturation, $\mathrm{pH}$, water temperature, and conductivity were measured hourly using a Hydrolab ${ }^{\circledR}$ Datasonde 4a from July 22 to August 5, 2013, and using a YSI ${ }^{\circledR}$ model 600XLM from August 5 to September 9, 2013, and from July 14 to September 9, 2014. Monitors at both sites were positioned horizontally and located $1 \mathrm{~m}$ off the substrate. The performance of water-quality monitors was checked during weekly site visits through comparison with freshly calibrated reference monitors. During weekly visits, water-quality monitors were either cleaned or replaced with clean and calibrated monitors. Monitors in Clear Lake Reservoir were deployed for 1 week at a time, whereas the monitors in Upper Klamath Lake were deployed for 3 continuous weeks before being replaced.

\section{Ammonia and Microcystin Sampling and Analysis}

Water samples were collected weekly from mid-July to mid-September 2013 and 2014 at one site in Clear Lake Reservoir and one site in Upper Klamath Lake. Sites were selected to create overlap with juvenile sucker capture locations and times. The water sample site in Clear Lake Reservoir was colocated with a USGS continuous water-quality monitor, site number 41500712110201. In Upper Klamath Lake, un-ionized ammonia and microcystin data were obtained from the USGS lower midnorth continuous monitoring and water sample site (USGS site number 422622122004000) in 2013. This site was located about $5 \mathrm{~km}$ from the areas where we collected suckers. To obtain data relevant to the location of sucker capture, a water sampling site was added near Fish Banks in 2014.

Integrated water column samples were collected for microcystin analysis by lowering two 1-L vented bottles at a constant rate from the surface to the bottom. Each sample was mixed in a churn splitter, and then divided into a primary and quality-control sample. These samples were transferred to high-density polyethylene (HDPE) bottles in 2013 and to amber glass bottles in 2014 and stored on ice. To ensure that sampling equipment was free from microcystin prior to sampling, blank samples were collected on 3 days in each lake at each site each year. Blank samples were the first samples collected on a given day, and were collected by pouring organic blank water into sample bottles, transferring it to the churn splitter, and then transferring the sample to sample bottles identical to bottles used for environmental samples. To assess the variability owing to mixing and analysis, the churn mixed sample was split into two samples for identical analysis every other week on each lake. To assess environmental variability within samples dates and locations, replicate samples were collected by repeating the entire sampling process on alternate weeks from split samples in each lake. In 2013, samples were shipped on ice overnight to the U.S. Geological Survey, Columbia Environmental Research Center, and processed within 24 hours. 
In 2014, Upper Klamath Lake samples were filtered within 24 hours through a $63-\mu \mathrm{m}$ sieve to separate the large particulates from the rest of the sample. There was no large particulate fraction in samples from Clear Lake Reservoir in 2014, so analysis was conducted on the whole sample. Samples were then frozen until they could be analyzed. The fraction of the sample retained on the sieve was considered the particulate fraction, and the filtrate from the sieving process was considered the dissolved fraction. The particulates were concentrated and re-suspended in tap water after filtering. The total volume of the field sample and the volume of tap water used to concentrate and resuspend the particulates were recorded and later used to calculate the concentration factor. Both particulate and dissolved fractions were processed through three freeze-thaw cycles prior to analysis to lyse whole Microcystis aeruginosa cells and release toxin into water.

Before analysis, the dissolved and large particle fractions of samples were filtered through either a $0.45-\mu \mathrm{m}$ or $0.3-\mu \mathrm{m}$ filter, depending on the filtering supplies available at the time. Samples filtered through $0.45-\mu \mathrm{m}$ mesh size were filtered using a $0.45-\mu \mathrm{m}$ UniPrep ${ }^{\mathrm{TM}}$ syringeless glass microfiber filter (Whatman, Inc., Clifton, New Jersey). Samples filtered through 0.3- $\mu \mathrm{m}$ mesh size were filtered using 25-mm $0.3-\mu \mathrm{m}$ pre-fired glass filters $\left(\right.$ Advantec $^{\circledR}$ ) and a glass filter holder, glass filter flask, and vacuum hand-pump. The filtrate was analyzed and the fraction remaining on the filter was discarded.

Particulate and dissolved fractions were diluted, when necessary, to bring the sample within the detection range of the analysis. Particulate and dissolved fractions were analyzed for unbound microcystin concentration using enzyme-linked immunosorbent assays (ELISA, kit PN 520011, Abraxis ${ }^{\circledR}$ LLC, Warminster, Pennsylvania). Sample absorbances were measured at $450 \mathrm{~nm}$, and calibration standards were analyzed with the samples for regression analysis of the mean absorbance of the standards. Microcystin concentrations were calculated using the regression from the calibration standards. Concentrated particulate results were multiplied by the concentration factor (volume of resuspended particulates $\div$ volume of field sample) to determine the final microcystin concentration for the particulate samples.

Water samples for ammonia were collected at mid-water column depth using a hose and peristaltic pump. Samples were directly deposited into 125-mL HDPE bottles and stored on ice. To ensure that sampling equipment was free from ammonia contamination, blank samples were collected prior to each environmental sample. To assess variability in the analytical procedure, two sequential samples were collected without changing the pump filter at each site every other week (split samples). To assess environmental and procedural variability within sites and sample dates, replicate samples using new filters were collected on alternating weeks from split samples. Samples were refrigerated at 4 ${ }^{\circ} \mathrm{C}$ for as many as 2 days prior to being transferred on ice to the Sprague River Water Quality Laboratory for analysis. Upon arrival, samples were refrigerated at $4{ }^{\circ} \mathrm{C}$ for as many as 10 days before being analyzed for ammonia as nitrogen (N) according to U.S. Environmental Protection Agency (1979a) protocols. The $\mathrm{pH}$ and temperature data recorded during sample collection were used to calculate the amount of un-ionized ammonia $\left(\mathrm{NH}_{3}\right)$ in each sample (U.S. Environmental Protection Agency, 1979b). 


\section{Fish Capture and Processing}

Fish were sampled using trap nets from the northwestern shore of Upper Klamath Lake and the southwestern and western shores of Clear Lake Reservoir in 2013 and 2014 (figs. 1 and 2). Previous sampling indicated that juvenile suckers were randomly distributed throughout both lakes during July to September regardless of age (Bottcher and Burdick, 2010; Burdick and Rasmussen, 2012). Therefore, we assumed that the age distribution of suckers in our catches represented that of each lake. Sampling occurred between July 22 and September 26, 2013, and between July 14 and October 22, 2014. Between 8 and 12 sample locations were randomly selected each week from 30 sites in each lake that were predetermined to be accessible under most water levels. Fish were collected in trap nets with rectangular mouth dimensions of $0.609 \times 0.914 \mathrm{~m}$, a $10-\mathrm{m}$ lead, and three internal fykes. These nets were green with 6.4-mm mesh nylon netting. Nets were set between 0759 and 1251 hours and pulled the next day between 0739 and 1659 hours for an average ( \pm standard deviation [SD]) soak time of $23.4 \pm 1.7$ hours.

Fishes other than suckers were quantified from a sub-set of nets with the goal of describing the potential juvenile sucker predators in 2013 and describing the overall fish communities in each lake in 2014. Between 2 and 12 nets from each lake were selected weekly for non-sucker sampling. Nets were selected for fish community sampling such that a wide spatial distribution within the sampling area in each lake was included. The SL and gape size at the widest point were measured for fishes considered to be potential predators of juvenile suckers, to determine if they were large enough to prey on the suckers present in our sampling. The species considered to be potential juvenile sucker predators included bullhead (Ameiurus spp.), sculpin (Cottus spp.), pumpkinseed (Lepomis gibbosus), yellow perch (Perca flavescens), and Sacramento perch in 2013. Largemouth bass (Micropterus salmoides) are present in Upper Klamath Lake and were considered a potential predator to juvenile suckers, but none were encountered in our sampling. In 2014, SL was measured for all species and gape size was not measured on any fish. Only the fish species measured in 2013 were counted that year, whereas in 2014 all species were counted.

Juvenile suckers as large as $225 \mathrm{~mm}$ SL were sacrificed with an overdose of tricaine methanesulfonate (MS222) to determine energy content, to look for histological evidence of disease and pathogens, and to quantify the unbound microcystin concentrations in tissues. To facilitate a comparison between fish of the same age, only suckers less than $90 \mathrm{~mm}$ SL were sacrificed in 2013. There seemed to be little production of suckers in Clear Lake Reservoir in either year of our study, leading to a lack of age- 0 juveniles. Therefore, to increase the number of sacrificed fish from Clear Lake Reservoir in 2014, suckers $225 \mathrm{~mm}$ SL or shorter were sacrificed throughout the sampling season. The first two out of every three sacrificed suckers were wrapped in dry Rite-n-Rain ${ }^{\circledR}$ paper, placed in clear Whirl-Pac ${ }^{\circledR}$ bags, and immediately placed on dry ice. These suckers were transferred to a $-80{ }^{\circ} \mathrm{C}$ freezer upon returning to the laboratory and were later analyzed for either triglyceride content or free microcystin concentrations in the tissues. The third out of every three suckers was slit open ventrally, examined for signs of physical, and placed in formalin fixative for histological examination. In 2013, digestive tissue was not well preserved. Therefore, in 2014, digestive tracks were snipped in several places prior to preservation to facilitate fixative penetration. Suckers were transferred from formalin to 70 percent ethanol after 72-96 hours. All formalin-fixed suckers were weighed to the nearest $0.1 \mathrm{~g}$ after returning to the laboratory. 
Prior to fixation or freezing, complete left leading pectoral fin rays were removed from all suckers for aging by cutting as close to the fin base as possible. Fin rays were dried and mounted in epoxy. Sections were taken from the proximal end of the fin ray and read under transmitted light at 5$10 \times$ magnification. Two technicians with 3 and 4 years of experience each counted the number of annuli on each sectioned structure. Prior to examining fin rays from wild-caught suckers, technicians examined five known age- 1 and five known age-2 hatchery-raised suckers to confirm the formation and placement of annuli. Technicians first examined structures independently with no knowledge of the other's age estimate so that aging bias among readers could be examined. When there was a discrepancy in the number of annuli, technicians examined fin ray sections together and came to a consensus about the estimated age of each fish. Structures from fish that were estimated to be older or younger than seemed reasonable based on their length were examined an additional time by both readers.

Field necropsies were performed to rapidly assess health and condition in 2014. External examinations were conducted for all suckers and internal examinations were noted for 27 suckers from Clear Lake Reservoir, and 77 suckers from Upper Klamath Lake. We classified organ condition following a modified version of methods described by Adams and others (1993). Condition of eyes was noted as normal, exophthalmic, hemorrhagic, blind, or missing. The condition of gills was noted as normal, frayed, clubbed, marginate (discolored on the ends), pale, or having lesions. The presence and location of external hemorrhages were documented. External parasites visible without magnification were counted and the location on the body of the fish was noted. Opercula shortening or malformation was noted as occurring on both sides, left side, right side, or neither side. Other deformities also were noted. After external examination was complete, the somatic cavity was carefully opened along the ventral line for internal examination. The amount of visceral fat was qualitatively assessed as high, moderate, or very low. Liver and spleen color was classified as normal (dark red) or off-color (pale, pink, or tan), and liver texture was noted as smooth, grainy, or lumpy. Livers described as normal were dark red and had a similar appearance to those observed for age-1 hatchery-reared Lost River suckers. To determine if conditions disproportionally applied to one taxa or the other, we compared mean and median probability of being a Lost River sucker (prob [LRS]) among groups using either t tests or Kruskal Wallis comparisons among medians. Significance was evaluated at the $\alpha=0.05$ level.

\section{Species Identification}

To identify juveniles collected in 2014 as shortnose or Klamath largescale suckers (Catostomus snyderi) (one group, hereafter referred to as "shortnose suckers") or Lost River suckers and shortnoseLost River hybrids, we applied genetic identification methods described by Hoy and Ostberg (2015). Caudal fin tissue was collected and dried from 442 juvenile suckers in 2014 . This collection represented 261 juveniles from Upper Klamath Lake and 181 juveniles from Clear Lake Reservoir.

Deoxyribonucleic acid (DNA) was extracted from the caudal tissues using DNeasy kits (Qiagen Inc. ${ }^{(\mathrm{R})}$, Valencia, California). A total of 18 nuclear DNA TaqMan ${ }^{\circledR}$ assays that differentiate the species based on single nucleotide polymorphisms (SNPs) was used (table 1; Hoy and Ostberg, 2015). A mitochondrial DNA (mtDNA) TaqMan ${ }^{\circledR}$ assay also was applied to identify the maternal lineage (Lost River or shortnose sucker) for each individual (Hoy and Ostberg, 2015). 
Table 1. The 18 nuclear deoxyribonucleic acid (DNA) TaqMan ${ }^{\circledR}$ assays and one mitochondrial DNA (mtDNA).

$\left[\operatorname{TaqMan}^{\circledR}\right.$ assays that were used to differentiate Lost River and shortnose suckers and to identify their hybrids were described by Hoy and Ostberg (2015)].

\begin{tabular}{l}
\multicolumn{1}{c}{ Assay ${ }^{1}$} \\
\hline Dlux176 \\
Dlux1678 \\
Dlux6487 \\
Dlux8444 \\
Dlux9136 \\
Dlux11471 \\
Dlux17848 \\
Dlux23154 \\
Dlux25918 \\
Dlux26237 \\
Dlux35885 \\
Dlux38658 \\
Dlux46804 \\
Dlux55662 \\
Dlux68397 \\
Dlux69085 \\
Dlux69338 \\
Dlux77486 \\
${ }^{1}$ Dlux434 \\
\hline
\end{tabular}

${ }^{1}$ mtDNA Taqman assay.

We used the program STRUCTURE, version 2.3 (Pritchard and others, 2000; Evanno and others, 2005), to probabilistically assign individual multilocus genotypes to the Lost River sucker and shortnose sucker based on the posterior distribution of the program output. STRUCTURE uses a Markov chain Monte Carlo (MCMC) simulation approach to identify the posterior probability $(q)$ for the proportion of an individual genotype derived from each of $K$ population clusters. We applied the admixture model with independent allele frequencies, given the high differentiation between Lost River and shortnose suckers. A total of 10 repetitions were run in STRUCTURE and the model parameters were as follows: (1) markers assumed to be unlinked; (2) 442 individuals; (3) 18 nuclear loci; (4) 2 populations assumed; and (5) 50,000 burn-in steps, followed by 100,000 MCMC iterations. We followed the procedure of Evanno and others (2005) to estimate the most probable number of $K$ population clusters. The most probable number of population clusters was $K=2$ (that is, Lost River and shortnose suckers). Therefore, admixture proportions between Lost River and shortnose suckers were estimated for each individual using the mean posterior probability over the 10 repetitions. 
Genetic probability of species assignments (genetic identifications) were used to summarize data, except histology and some multiyear comparisons. Meristic species identifications were based on methods described by Markle and others (2005). Meristic species identification required x-rays to be taken of suckers so that vertebrae could be counted. This process thawed frozen fish and had the potential to jeopardize the quality of some analyses. Therefore, we only x-rayed and identified suckers to species using meristic data if they were preserved in formalin. Both methods (genetic and meristic species identifications) provided similar species identifications, but the genetic method provided more information on the level of genetic mixing between taxa (Hoy and Ostberg, 2015).

\section{Triglyceride Analysis}

Twelve wild suckers not identified to species from Upper Klamath Lake and one wild sucker from Clear Lake Reservoir were included in the triglyceride analysis in 2013. The wild sucker from Clear Lake Reservoir was captured on September 10, 2013, and the wild Upper Klamath Lake suckers used for triglyceride analysis were collected on August 8 (1), August 15 (3), and September 5 (8), 2013. Thirty-nine shortnose suckers from Clear Lake Reservoir and 46 shortnose suckers and 46 Lost River suckers from Upper Klamath Lake collected in 2014 were included in the triglyceride analysis. These fish were sampled between July 22 and September 11, 2014, in Clear Lake Reservoir, and between July 10 and September 11, 2014, in Upper Klamath Lake. At least 2 and no more than 14 fish from each lake each week were included in the 2014 analysis.

Whole body triglyceride content was assayed at the California-Nevada Fish Health Center in Anderson, California, using a modification of methods described by Weber and others (2003). Water was added to fish tissue at a ratio of $1 \mathrm{~mL}$ per gram of fish to enable homogenization. Isopropanol was added to an aliquot of homogenate in the ratio of $4 \mathrm{~mL}$ per gram of fish. Samples were processed for 20 minutes at room temperature in a revolving sample mixer before being centrifuged at $3,220 \times$ gravity for 5 minutes. Three replicate $10-\mu \mathrm{L}$ samples of $10 \times$ diluted supernatant were added to microplate wells and reacted with a triglyceride reagent (triglyceride GPO kit, Pointe Scientific, Inc. ${ }^{\mathrm{TM}}$, Canton, Michigan). The triglyceride reagent produces red-colored quinoneimine dye in concentrations directly proportional to triglyceride concentrations. The optical density was measured in a colorimetric spectrometer and the milligrams of triglycerides per gram of fish were calculated.

Triglyceride content per body weight (mg/g) was compared between species, among age groups, and across time within lakes when samples were available in 2014 . Small sample sizes $(\mathrm{n} \leq 13)$ for age classes in Clear Lake Reservoir prevented a formal statistical comparison of triglyceride content among age classes, so data were visually displayed in boxplots. A general linear model was used to examine the relations between triglyceride content and date of capture and prob [LRS] for age- 0 suckers captured in Upper Klamath Lake. Because of a lack of species diversity among juvenile suckers in Clear Lake Reservoir, we fit a separate linear model to examine the effect of date of capture on triglyceride content for all ages combined, but did not include a variable for prob [LRS]. 


\section{Growth and Condition Assessment}

We used SL data to assess apparent intra- and inter-annual growth rates (changes in SL over time) relative to age, lake, and prob [LRS] when we had sufficient data to do so. To examine variation in size at age among cohorts, we included estimated age and SL data for suckers collected in Clear Lake Reservoir in 2011 and 2012 (Burdick and Rasmussen, 2012; 2013). Because within years age-0, sucker length data were either not available in both lakes or were very sparse in Clear Lake Reservoir (that is, $\mathrm{n}=10$ in 2013), a statistical test comparing lengths or growth between lakes was determined to be inappropriate. Therefore, we visually compared length data between lakes for age- 0 suckers caught from 2012 to 2014 using histograms. The annual mean and distribution of age-0 sucker lengths (both species combined) was compared between 2013 and 2014 using a t-test and Kolmogorov-Smirnov test (respectively). We fit a general linear model with length as the response variable, and day of year and prob [LRS] as independent variables to determine the effect of species on growth.

To assess the relative condition of suckers captured in our study, we compared the length-weight relationships between groups of sacrificed suckers based on species, lake, and year. In this analysis, we used meristic species identifications because genetic identifications only were available in 2014 . We calculated Fulton's condition factor for individual fish (Neumann and others, 2012). We restricted statistical analyses to groups with length, weight, and meristic species data on at least 15 suckers. We compared condition factors between shortnose suckers collected in 2014 and shortnose suckers collected in 2013 from Clear Lake Reservoir (Burdick and Rasmussen, 2013). We also compared condition factors between lakes for shortnose suckers collected in 2014. Means were compared with t-tests and distributions were compared with Kolmogorov-Smirnov tests. Analyses were performed using the base package in program $\mathrm{R}$ version 2.15.2 (R Core Team, 2012) and all comparisons were considered significant at the $\alpha=0.05$ level.

\section{Histopathology}

In 2013, 18 wild and 10 hatchery suckers were examined by histology. Wild fish were collected from the southern (August 6 and September 10, 4 fish) and western (September 24 and 26, 2 fish) shores of Clear Lake Reservoir, and from Fish Banks in Upper Klamath Lake (August 15-29, 7 fish; and September 4 and 5, 5 fish). Ten age-1 Lost River suckers were sampled from the Klamath Tribes Fish Hatchery on November 6.

Fifty fish sampled during 2014 were examined by histology including wild fish sampled from the southern shore of Clear Lake Reservoir (July 30-August 7, 10 fish; and August 7-September 10, 10 fish) and from Fish Banks in Upper Klamath Lake during periods of low microcystin concentrations (July 15-17; 10 fish) and during the increasing and decreasing periods in microcystin concentrations (August 5-7, 10 fish; and August 26--September 11, 10 fish, respectively). 
Fish were fixed in Carson's modified Millonig phosphate-buffered formalin (Carson and others, 1973). Tissues collected for 2013 histopathological analysis included the gills, anterior kidney, posterior kidney, liver, spleen, pancreatic tissue including interpancreatic connective tissue, and gastrointestinal tract. Additional tissues examined from fish sampled in 2014 included the heart, and skin and skeletal muscle from fish with external lesions or parasites. Tissues were subjected to routine paraffin processing, sectioned at $5 \mu \mathrm{m}$ and stained with hematoxylin and eosin.

The presence and appearance of vacuoles and staining characteristics of hepatocyte cytoplasm were used to explore liver energy storage as another possible indicator of the nutritional status of fish. Liver tissue was stained with periodic acid-Schiff (PAS) and PAS-diastase (Carson, 1997) to estimate the amount of glycogen stored in hepatocyte cytoplasm. Glycogen distribution levels were rated as none, focal (low levels), or diffuse (high levels). The presence of hepatocellular vacuoles morphologically consistent with lipid storage also was noted. We used Fisher's exact test to determine if liver color was correlated to hepatocyte glycogen and vacuolation levels.

All tissues were examined by light microscopy with a Zeiss ${ }^{\circledR}$ Axiophot ${ }^{\mathrm{TM}}$ photomicroscope, and the degree of tissue response including inflammation and necrosis per field at $200 \times$ magnification was recorded and scored using a 4-point scale. Distribution of histological changes was scored as none, focal, multifocal or diffuse; severity was scored as none to minimal, mild, moderate, or severe. The location and identification of parasites and the degree of host response to parasites also were recorded.

\section{Analysis of Unbound Microcystin in Fish Tissue}

Twelve age- 0 suckers (species unknown) collected in 2013 and three age- 0 suckers collected in 2014 from Upper Klamath Lake were analyzed for unbound microcystin concentrations in the trunk (muscle tissue) and viscera. Frozen samples were lyophilized, and then dissected with surgical scissors. The head anterior to the operculum was removed and the tail from the urogenital/anal opening rearward was removed, along with the remaining fins. The remaining trunk was split along the ventral surface and the viscera were scraped out with a spatula. Two parts of the body were analyzed: (1) $50 \mathrm{mg}$ of the trunk, and (2) one-half the weight of the viscera.

Tissue samples were analyzed by high-performance liquid chromatography (HPLC) with ultraviolet (UV)- diode array detection for direct measurement of unbound micocystin in the extract. Extraction was performed by first adding $0.01 \mathrm{M}$ ethylene diamine tetraacetic acid disodium (EDTA$\mathrm{Na}_{2}$ ), 5 percent acetic acid, and $3 \mathrm{M} \mathrm{NaCl}$; sonicating at $0{ }^{\circ} \mathrm{C}$; and centrifuging for 5 minutes at $1,207 \times$ gravity. The sample extract was rotary evaporated at $40{ }^{\circ} \mathrm{C}$ to near dryness and $10 \mathrm{~mL}$ of methanol was added to precipitate the salts and hydrophilic endogenous compounds. Methanol was evaporated at 40 ${ }^{\circ} \mathrm{C}$ to near dryness and samples were rehydrated with water. The sample was fractionated through a 225mg Waters Oasis ${ }^{\mathrm{TM}}$ HLB cartridge by use of a Supelco vacuum chamber. The methanol-collected fraction was rotary evaporated again at $40{ }^{\circ} \mathrm{C}$ to near dryness and $2 \mathrm{~mL}$ of methanol was added. The sample was fractionated through a 2-g Waters ${ }^{\circledR}$ Sep-Pak Vac SPE silica gel cartridge. The collected fraction of methanol was rotary evaporated a third time and transferred to an amber conical auto sampler vial and evaporated to $0.02 \mathrm{~mL}$ under a nitrogen $\left(\mathrm{N}_{2}\right)$ steam. A $10-\mu \mathrm{L}$ aliquot of a $1.0-\mu \mathrm{g} / \mathrm{mL}$ Nodularin standard as a retention time marker was added prior to diluting the sample to $200 \mu \mathrm{L}$ with 0.05 percent trifluoracetic acid. Finally, $50 \mu \mathrm{L}$ was injected into the HPLC machine. 
The analysis was carried out by automated injections on a Dionex ${ }^{\mathrm{TM}}$ UltiMate $^{\circledR} 3000$ HPLC Chromatography System (Thermo Scientific ${ }^{\mathrm{TM}}$, Sunnyvale, California). The column used was a $100 \times$ $4.6 \mathrm{~mm}$ Phenomenex Kinetex PFP $(2.6 \mu \mathrm{m}, 100$ angstroms $[\AA])$ with a Rheodyne $2-\mu \mathrm{m}$ particle filter attached to the inlet of the column (Thermo Scientific ${ }^{\mathrm{TM}}$, Sunnyvale, California). The column was held at $40{ }^{\circ} \mathrm{C}$ during the analysis. The analysis was by UV detection using a diode array detector monitoring wavelength $238 \mathrm{~nm}$ for the microcystins. The gradient elution used a mpbile phase mixture consisting of two parts: (1) 0.05 percent trifluoracetic acid (TFA) in methanol, and (2) 0.05 percent TFA in Millipore 18 megaohm cm water.

Quality assurance was preformed by replicate injections, blanks, and spikes. Replicate injections were made of two trunk and one viscera sample, with equal results for the replicate injections. Procedure and matrix blanks were run. Matrix spikes at $40 \mathrm{ng}$ for each of five congers of microcystin (RR, YR, LR, LY, LA, LW, and LF) were run, and chicken liver spikes were run at 10 and $40 \mathrm{ng}$ for all five congers.

\section{Results}

\section{Continuous Water-Quality Monitoring Data}

Dissolved-oxygen concentrations and $\mathrm{pH}$ were more variable in Upper Klamath Lake than in Clear Lake Reservoir, but the opposite was true for temperature patterns compared between lakes (figs. 3-5). Dissolved-oxygen concentrations ranged from 1.3 to $10.9 \mathrm{mg} / \mathrm{L}$ in Upper Klamath Lake and from $5.7 \mathrm{mg} / \mathrm{L}$ to $8.6 \mathrm{mg} / \mathrm{L}$ in Clear Lake Reservoir. Dissolved-oxygen measurements less than $4 \mathrm{mg} / \mathrm{L}$, an established stress threshold for suckers (Loftus, 2001), only occurred in 4 percent of hourly measurements in Upper Klamath Lake in either year, but lasted up to 17 consecutive hours (fig. 3). The maximum diel change in DO concentration in Upper Klamath Lake was $7.1 \mathrm{mg} / \mathrm{L}$, whereas in Clear Lake Reservoir it was only $1.85 \mathrm{mg} / \mathrm{L}$. The $\mathrm{pH}$ ranged from 7.2 to 9.7 in Upper Klamath Lake and from 8.4 to 8.9 in Clear Lake Reservoir (fig. 4). Maximum daily change in $\mathrm{pH}$ was 1.4 in Upper Klamath Lake and only 0.4 in Clear Lake Reservoir. Water temperature ranged from $18.4{ }^{\circ} \mathrm{C}$ to $24.9^{\circ} \mathrm{C}$ in Upper Klamath Lake and from $15.7^{\circ} \mathrm{C}$ to $26.2^{\circ} \mathrm{C}$ in Clear Lake Reservoir (fig. 5). Maximum daily changes in water temperature were $2.2^{\circ} \mathrm{C}$ in Upper Klamath Lake and $6.5^{\circ} \mathrm{C}$ in Clear Lake Reservoir.

\section{Ammonia}

Quality-control samples indicated that ammonia measurements were precise but sometimes biased slightly high. Ammonia $\left(\mathrm{NH}_{4}{ }^{+}\right)$concentrations in split and replicate samples varied by 0.016 $\mathrm{mg} / \mathrm{L}$ or less from the primary samples collected on the same date, indicating variation in the data owing to sampling or analytical procedures was minor. Ammonia $\left(\mathrm{NH}_{4}{ }^{+}\right)$exceeded the minimum reporting limit by no more than 0.002 in 52 percent of blank samples and was lower in all other blank samples. After the August 5, 2013 sample, the pump filters were determined to be the source of this minor contamination and the problem was corrected by flushing the filters for a few additional minutes prior to sample collection. Minor contamination in ammonia concentrations in the blank samples in 2014 was determined to be owing to incomplete rinsing of the filter hose and was corrected in the last week of the season. In all cases, the potential error introduced from ammonia contamination of samples was very low and unlikely to bias the measured concentrations by an amount significant to suckers. 
Un-ionized ammonia concentrations $\left(\mathrm{NH}_{3}\right)$ in Clear Lake Reservoir were near or less than the minimum reporting limit of $0.002 \mathrm{mg} / \mathrm{L} \mathrm{NH}_{3}$ at $\mathrm{pH} 8.5$ and $20^{\circ} \mathrm{C}$. On four occasions, the un-ionized ammonia concentration in primary samples from Clear Lake Reservoir exceeded the minimum reporting limit by no more than $0.002 \mathrm{mg} / \mathrm{L}$. On three of these dates, the blank sample also exceeded the minimum reporting limit, indicating that the ammonia may have been a result of contamination rather than environmental concentrations. On August 25, 2014, calculated un-ionized ammonia concentrations in the primary sample exceeded the minimum reporting limit by less than $0.001 \mathrm{mg} / \mathrm{L}$ as $\mathrm{NH}_{3}$ and was associated with a blank sample with a concentration less than the reporting limit.

Un-ionized ammonia concentrations in Upper Klamath Lake nearly always exceeded the reporting limit (fig. 6). The highest un-ionized ammonia concentrations during our 2013 sampling season at the mid-north Upper Klamath Lake site occurred on July 16 and August 6 at $0.18 \mathrm{mg} / \mathrm{L}$ and $0.17 \mathrm{mg} / \mathrm{L}$ respectively. Concentrations of un-ionized ammonia at the mid-north Upper Klamath Lake site during our 2014 sampling season peaked at $0.28 \mathrm{mg} / \mathrm{L}$ on July 14, and remained high relative to the rest of the season in the July 21 sample. Un-ionized ammonia concentrations at the Fish Banks site were 37 percent or less of concentrations measured at mid-north on similar dates.

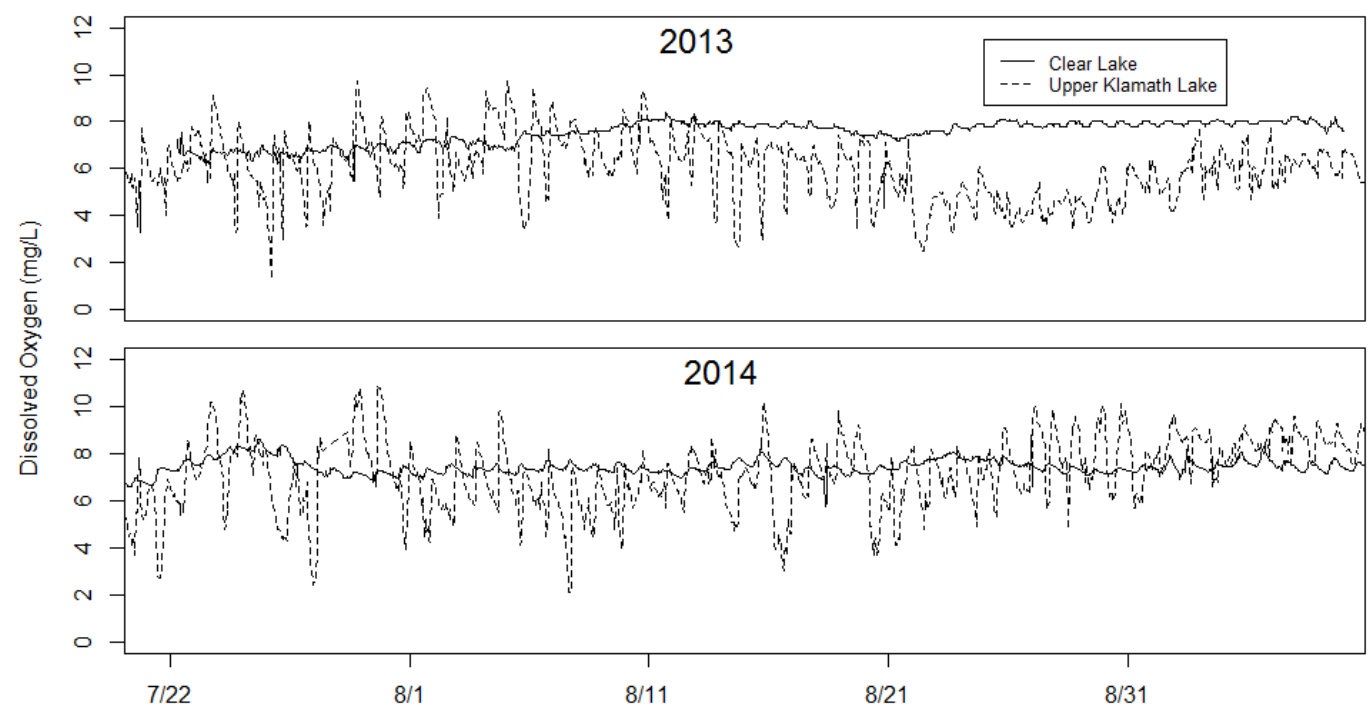

Figure 3. Dissolved-oxygen concentrations in Clear Lake Reservoir (U.S. Geological Survey site number 415007121102001), California, and at the lower mid-north site (U.S. Geological Survey site number 422622122004000) in Upper Klamath Lake, Oregon, during sucker sampling periods, 2013-14. Site locations are shown in figures 1 and 2 . Dates are given along the $x$-axis for the Monday of each week. 


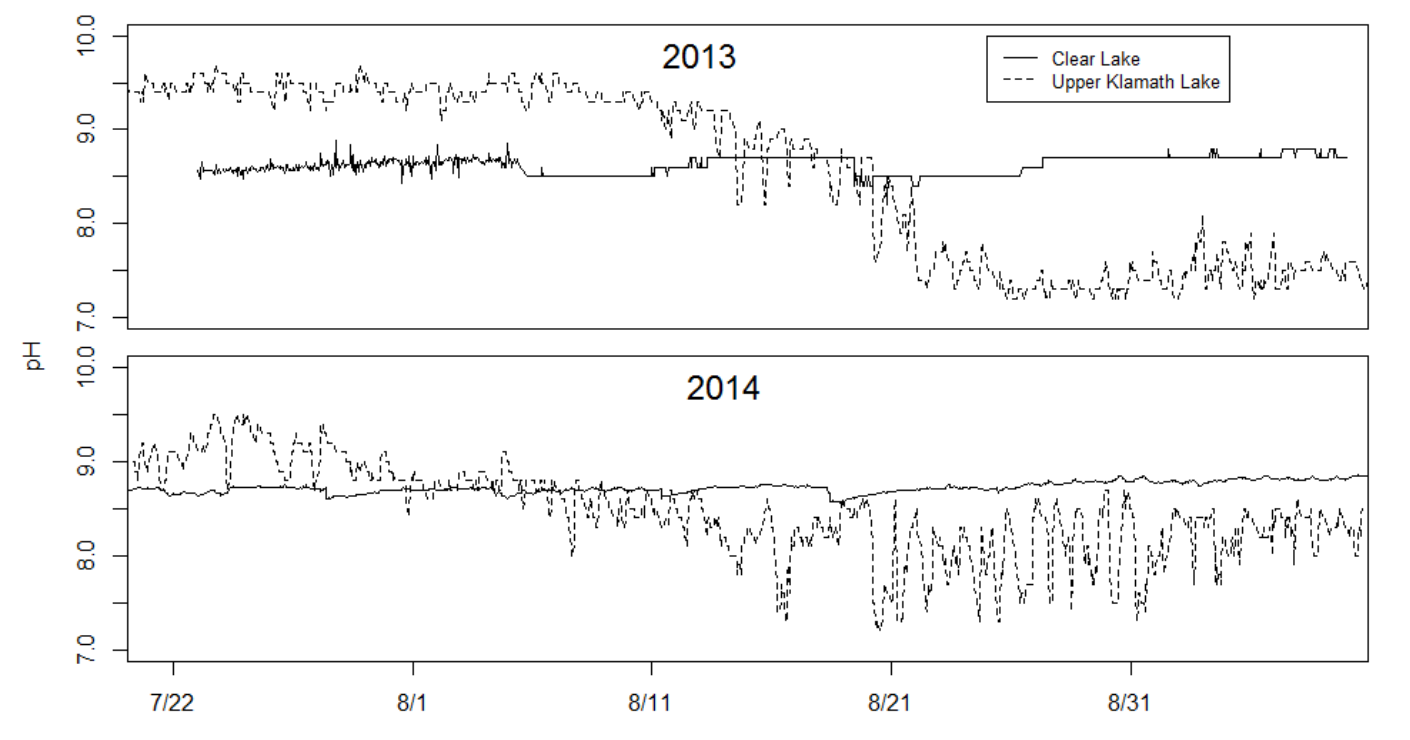

Figure 4. Values of pH in Clear Lake Reservoir (U.S. Geological Survey site number 415007121102001), California, and at the lower mid-north site (U.S. Geological Survey site number 422622122004000) in Upper Klamath Lake, Oregon, during sucker sampling periods, 2013-14. Site locations are shown in figures 1 and 2. Dates are given along the $x$-axis for the Monday of each week.

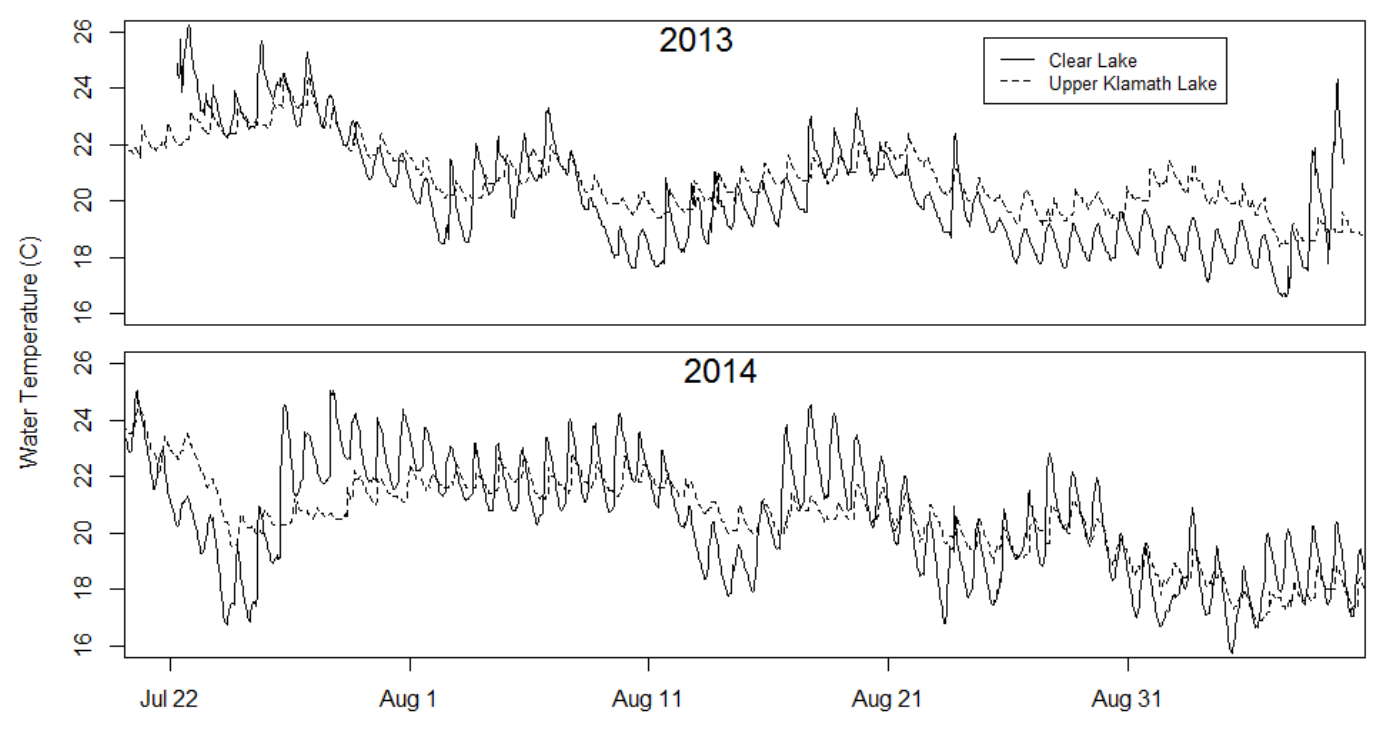

Figure 5. Water temperature (in degrees Celsius) in Clear Lake Reservoir (U.S. Geological Survey site number 415007121102001), California, and at the lower mid-north site (U.S. Geological Survey site number 422622122004000) in Upper Klamath Lake, Oregon, during sucker sampling periods, 2013-2014. 


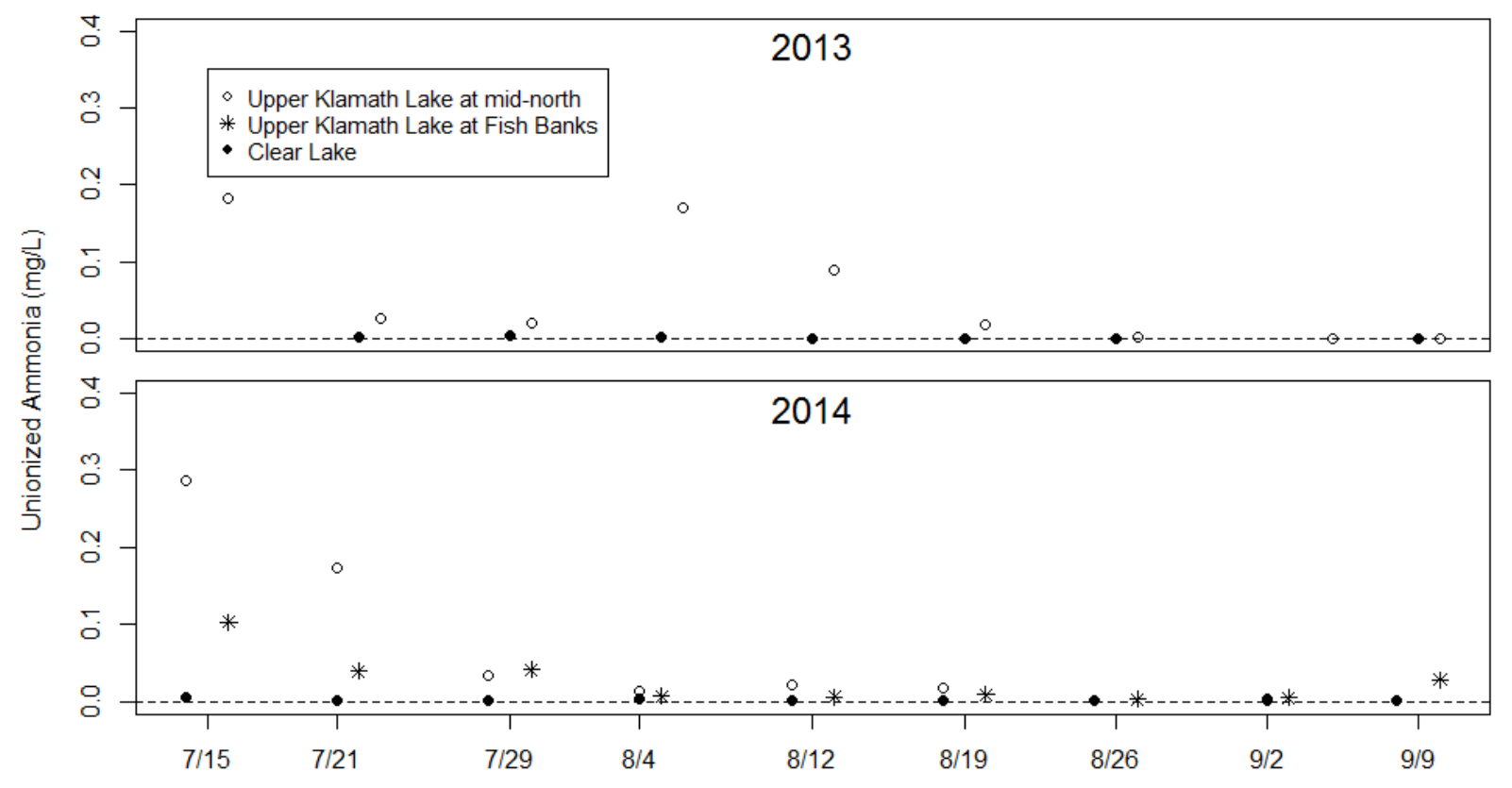

Figure 6. Un-ionized ammonia concentrations at Fish Banks and lower mid-north (U.S. Geological Survey site number 422622122004000) sites in Upper Klamath Lake, Oregon, and in Clear Lake Reservoir, California (U.S. Geological Survey site number 415007121102001), during sucker sampling seasons, 2013-14. The reporting limit is indicated by a dashed line in each panel.

\section{Microcystin Concentrations in Water}

Quality-control samples indicated that microcystin measurements were unbiased, and local spatial and sampling variation was small most of the time. Microcystin was not detectable in all six blank samples, indicating that there was no contamination and measured concentrations were not biased because of the sampling procedure and equipment. Microcystin concentrations varied between split samples by no more than $0.79 \mu \mathrm{g} / \mathrm{L}$ in the particulate fraction and no more than $0.17 \mu \mathrm{g} / \mathrm{L}$ in the dissolved fraction. Concentrations in most replicate samples varied by no more than $0.85 \mu \mathrm{g} / \mathrm{L}$. The exception was the difference between concentrations in the particulate fraction of replicate samples collected from Fish Banks on August 20, 2014. These samples had concentrations of 40.4 and 44.3 $\mu \mathrm{g} / \mathrm{L}$, the highest measured in our study.

Microcystin concentrations in Clear Lake Reservoir were near or less than the minimum reporting limit $(0.10 \mu \mathrm{g} / \mathrm{L})$ in both years. Microcystin was detected on three sampling dates in 2013 and on two dates in 2014. Concentrations were less than the reporting limit in all particulate fraction samples from Clear Lake Reservoir collected in 2013. Microcystin concentrations in Clear Lake Reservoir exceeded the minimum reporting limit by no more than $0.08 \mathrm{mg} / \mathrm{L}$ in the dissolved fraction on two dates in 2013 and in whole water samples on two dates in 2014. 
Microcystin concentrations in Upper Klamath Lake were low in both the dissolved and particulate fractions of samples collected in 2013 compared to 2014. Dissolved concentrations were less than the detection limit until August 6, and peaked at $0.43 \mu \mathrm{g} / \mathrm{L}$ on August 27, 2013. Particulate concentrations climbed slowly throughout the sampling season of 2013, with a maximum concentration of $0.70 \mu \mathrm{g} / \mathrm{L}$ measured on September 10. Microcystin concentrations were greatest in the particulate fraction of the water samples collected from Fish Banks in 2014 and followed a seasonal trend (fig. 7). In the particulate fraction at Fish Banks, concentrations of microcystins were elevated at $16.62 \mu \mathrm{g} / \mathrm{L}$ or greater from August 13 to September 3 (fig. 7). In comparison, concentrations of microcsystins in the dissolved fraction of Fish Banks samples were less than or near the detection limit until August 20 when they increased sharply to their seasonal peak of $4.55 \mu \mathrm{g} / \mathrm{L}$.

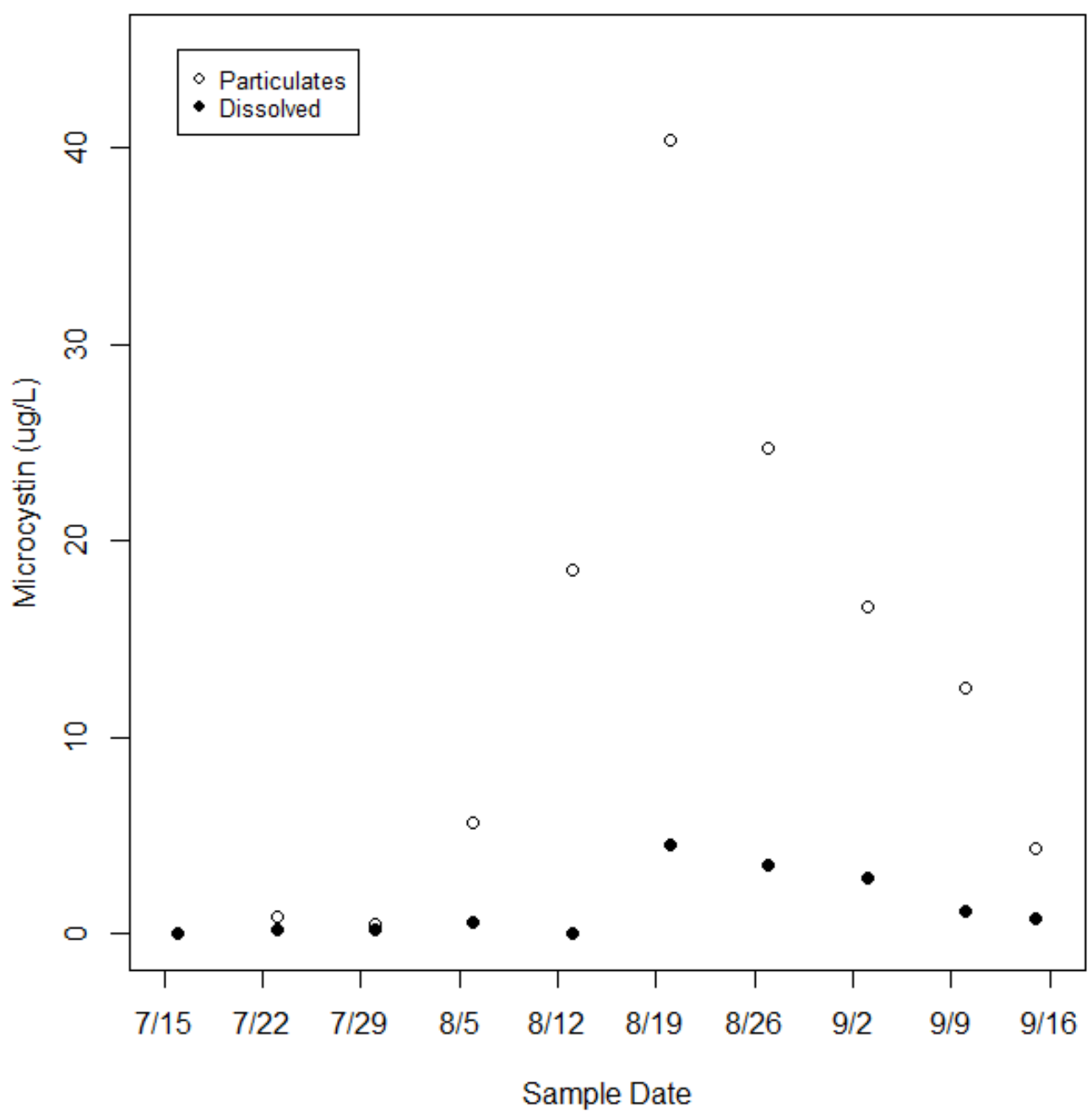

Figure 7. Concentrations of microcystin at Fish Banks and lower mid-north (U.S. Geological Survey site number 422622122004000) sites in Upper Klamath Lake, Oregon, during sucker sampling seasons, 2014. Particulate ( $\geq 63$ $\mu \mathrm{m})$ and dissolved fractions $(<63 \mu \mathrm{m})$ of the same water sample are shown. 


\section{Fish Assemblages}

All fish species combined were more abundant and a greater number of fish species were present in Upper Klamath Lake compared to Clear Lake Reservoir in 2014. Catch rates (fish per net) for fish overall were nearly $4 \times$ greater in Upper Klamath Lake than in Clear Lake Reservoir in 2014. We caught 5 species in Clear Lake Reservoir and 10 species in Upper Klamath Lake in addition to suckers. Sacramento perch made up 51 percent and fathead minnow made up 41 percent of fish captured in Clear Lake Reservoir in 2014. The other 8 percent of fish captured in Clear Lake Reservoir included blue chub (Gila coerulea), tui chub (Gila bicolor), marbled sculpin (Cottus klamathensis), and suckers. The three most common species in Upper Klamath Lake were fathead minnow (36 percent), tui chub (32 percent), and yellow perch (15 percent). Slender sculpin (Cottus tenuis) and brown bullhead made up less than a one-half of 1 percent of the Upper Klamath Lake catch. The remaining proportion of the Upper Klamath Lake catch was nearly evenly distributed among blue chub, Klamath Lake sculpin (Cottus princeps), marbled sculpin, pumpkinseed, and suckers. Although fathead minnow made up a larger proportion of the catch in Clear Lake Reservoir, they were $3.4 \times$ more abundant in our Upper Klamath Lake catches.

On average, suckers were the largest species in Clear Lake Reservoir, but were of a similar size to most species in Upper Klamath Lake. The exception was brown bullheads, which were on average about $3 \times$ larger than suckers in Upper Klamath Lake. At least two cohorts were apparent based on length frequency data for brown bullheads, yellow perch, Sacramento perch, pumpkinseed, and tui chub. We captured brown bullheads as large as $235 \mathrm{~mm}$ SL, yellow perch as large as $204 \mathrm{~mm}$ SL, Sacramento perch as large as $170 \mathrm{~mm} \mathrm{SL}$, and pumpkinseed as large as $113 \mathrm{~mm}$ SL. Ninety percent of potential predators in either lake had a gape of $18 \mathrm{~mm}$ or less. Of the potential fish predators with larger gapes, 88 percent were brown bullheads in Upper Klamath Lake (maximum $=49 \mathrm{~mm}$ ), 8 percent were Sacramento perch in Clear Lake (maximum $=24 \mathrm{~mm}$ ), and 4 percent were yellow perch in Upper Klamath Lake (maximum $=24 \mathrm{~mm}$ ).

\section{Sucker Catch Summary}

Catches of age-0 suckers in Upper Klamath Lake were about three $\times$ as high and primarily occurred earlier in 2014 than in 2013 (fig. 8). Most captures in 2013 (75 percent) occurred between August 15 and September 5. A substantial decrease in the percentage of successful nets or highest number of fish per net was not recorded in 2013 until the week of September 11. In contrast, most age- 0 suckers in 2014 (75 percent) were captured between July 14 and August 20. The percentage of successful nets decreased slightly during the week of August 25, 2014.

In Clear Lake Reservoir, the percentages of nets to capture at least one sucker were greater in 2013 than 2014, but peak catches were greater in 2014 than 2013 (fig. 9). The highest catches of 2014 occurred during the weeks of July 28 and August 4. Clear Lake Reservoir catches were fairly constant in 2013 but decreased somewhat in September 2014. 


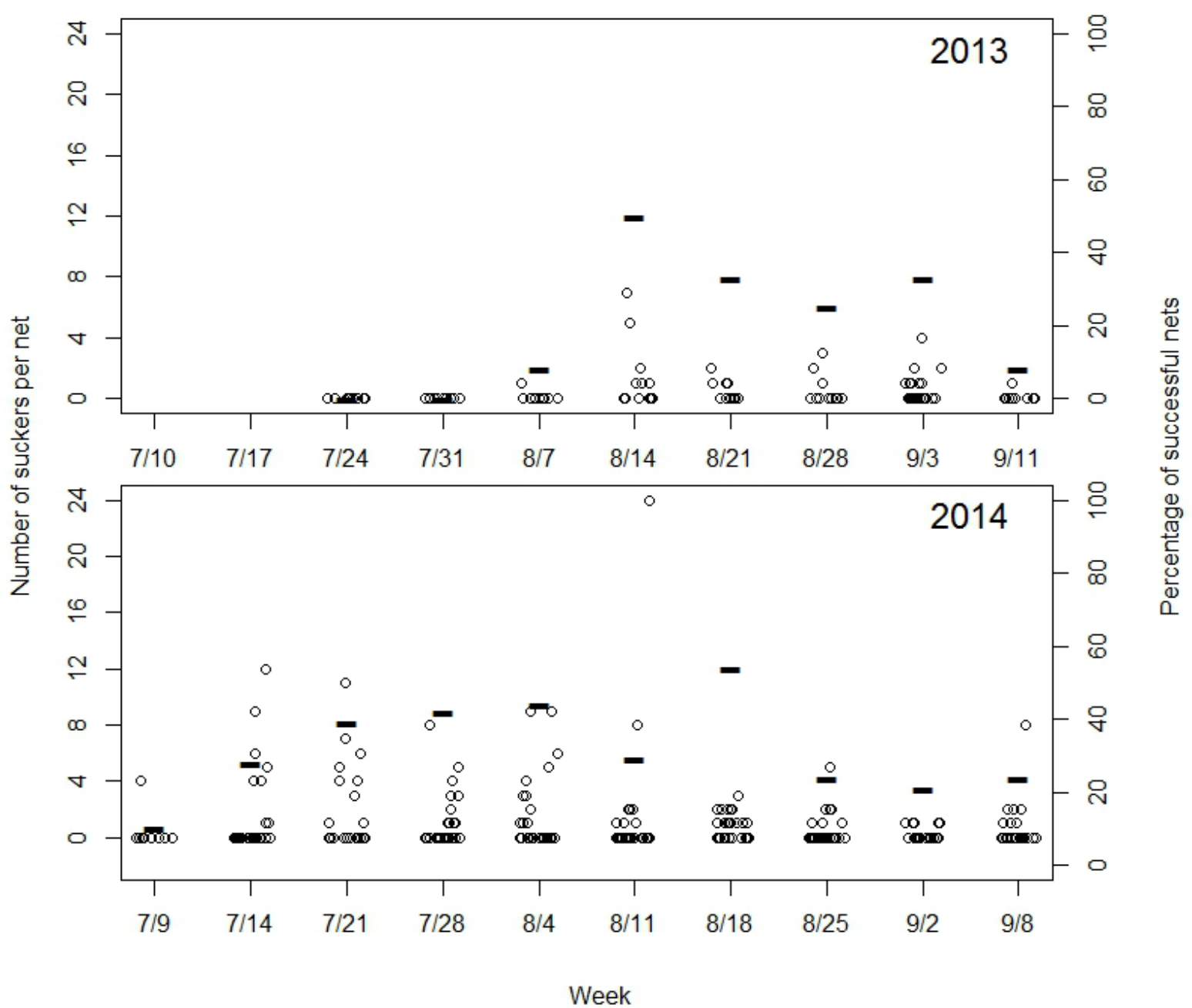

Figure 8. Catch rates and timing of age- 0 sucker captures along Fish Banks in Upper Klamath Lake, Oregon, 2013-14. Catch rates were jittered along the $x$-axis in each week to improve the display. Number of suckers captured per net (dots) and percentage of nets successful at capturing one or more sucker (lines) are shown. Data are shown for all sucker species combined. Dates are given for the Monday starting each week. 


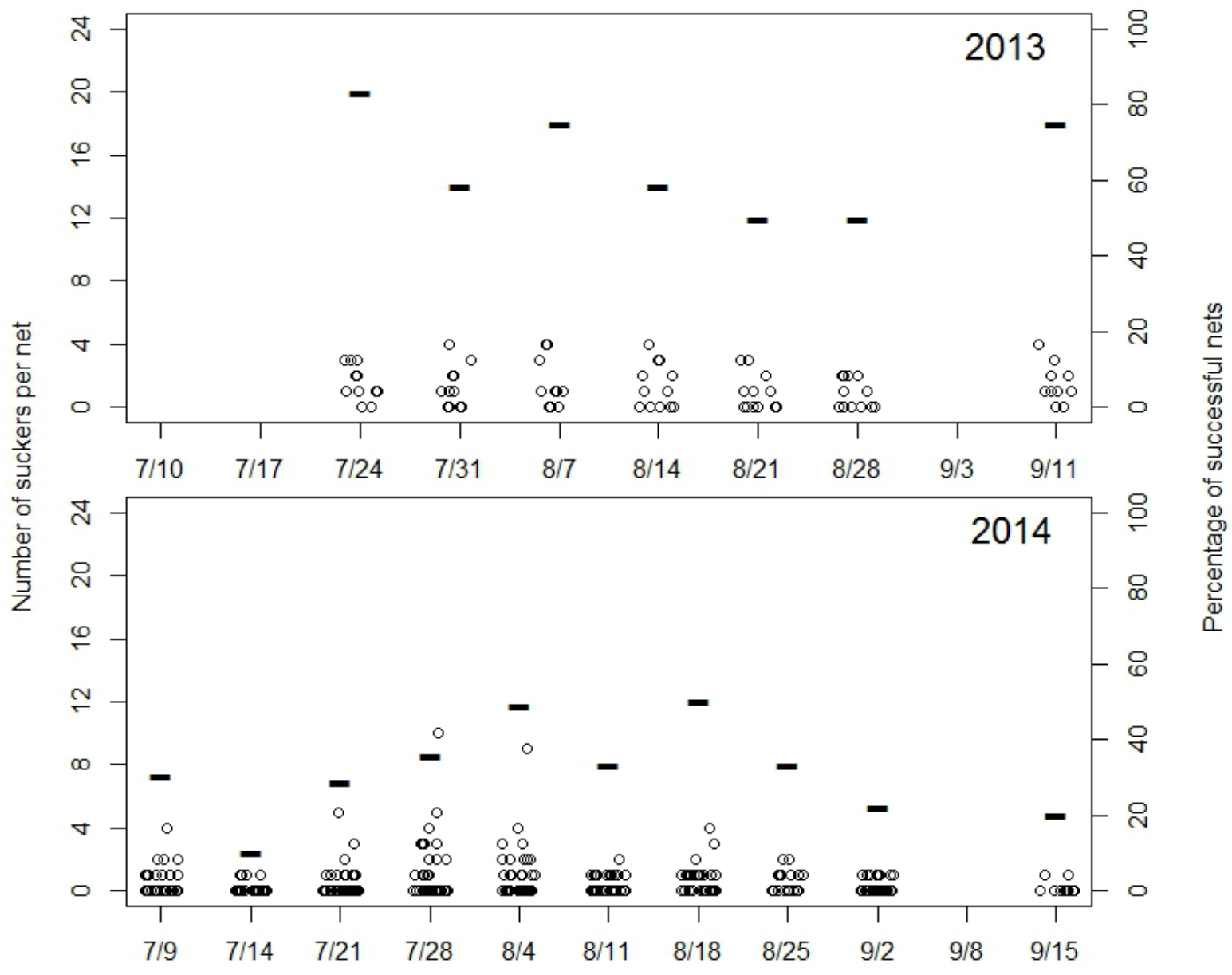

Week

Figure 9. Catch rates and timing of sucker captures (ages combined) in Clear Lake Reservoir, California, 201314. Number of suckers captured per net (dots) and percentage of nets successful at capturing one or more sucker (lines) are shown. Data are shown for all sucker species combined. Dates are given for the Monday starting each week.

\section{Species Identification}

Four suckers captured in Clear Lake Reservoir in 2013 were identified to species by meristics; all had fewer than 44 vertebrae and had either 27 or 28 gill rakers, indicating they were shortnose suckers. In a sample of 12 suckers captured from Upper Klamath Lake in 2013, 4 suckers had more than 44 vertebrae and, therefore, were considered to be Lost River suckers. Another 8 suckers captured from Upper Klamath Lake in 2014 had either 43 or 44 vertebrae and were considered to be shortnose suckers based on their number of gill rakers at length. 
Although most Clear Lake Reservoir suckers had a very low prob [LRS], there was a large degree of introgression between young-of-the-year Lost River and shortnose suckers in Upper Klamath Lake (fig. 10). A total of 178 of 181 suckers sampled from Clear Lake Reservoir in 2014 had a 0.03 or lower prob [LRS]. One sucker collected from Clear Lake Reservoir in 2014 had a greater than 0.99 prob [LRS] and another two suckers were likely hybrids. The prob [LRS] for one of these hybrids was 0.50 and the prob [LRS] for the other hybrid was 0.25 . In contrast, just over one-half of the suckers (54 percent) collected from Upper Klamath Lake in 2014 could be assigned a genetic species identification with a 0.97 probability or better. However, there was a wide distribution in the rest of the species assignment probabilities for Upper Klamath Lake fish (fig. 10).

Hybridization events between Lost River and shortnose suckers appeared to be asymmetrical. The analysis of mtDNA indicated that the maternal ancestry was exchanged across species in both lakes, but this exchange was not uniform. For example, 31 of 178 suckers (17 percent) captured in Clear Lake Reservoir that had a high probability of assignment $(\geq 0.97)$ to shortnose sucker had the Lost River sucker mitotype. In Upper Klamath Lake, 14 percent of suckers with a moderately high probability of assignment to shortnose sucker $(\geq 0.8)$ had the Lost River sucker mitotype. However, 112 of 113 suckers captured from Upper Klamath Lake with a moderately high prob [LRS] had the Lost River mitotype.

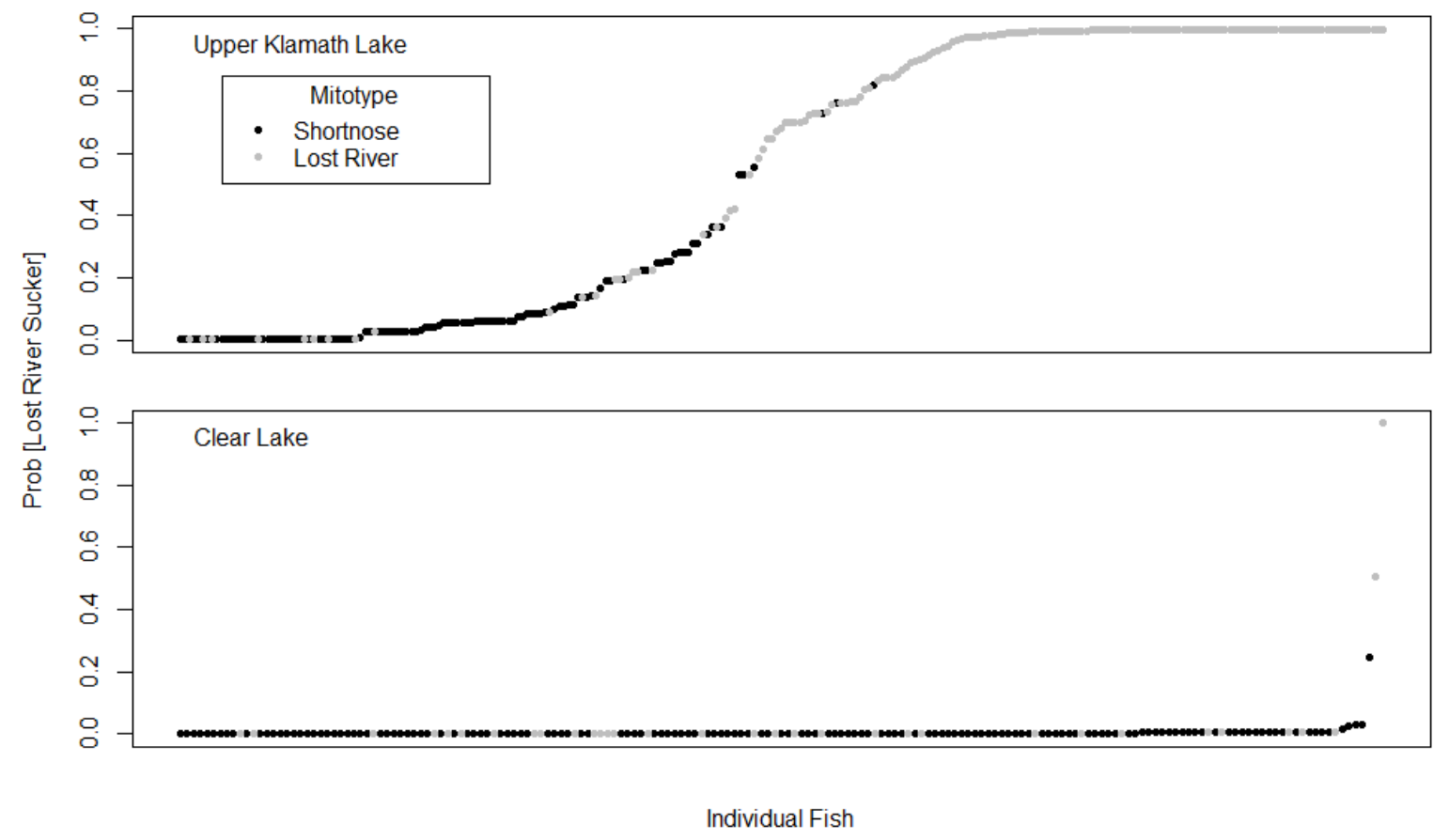

Figure 10. Probability of genetic assignment as Lost River sucker by individual fish collected in Upper Klamath Lake, Oregon, and Clear Lake Reservoir, California. Probabilities were assigned based on STRUCTURE analysis that used 18 nuclear single nucleotide polymorphisms. Mitotypes for each individual fish are indicated. 


\section{Sucker Ages}

Multiple reads of fin ray sections by two readers indicated that aging precision was fairly good. Readers estimated the same age for 87 percent of fin rays that they reread several weeks apart. For an additional 7 percent, the estimated age only changed by a single year between reads. Nevertheless, readers occasionally ( 6 percent) disagreed with their own estimated age between reads by $2-3$ years. A comparison between the best (as determined by the reader) blind estimates by each reader indicated a 76 percent agreement rate. Readers disagreed by 1 year on another 18 percent of fin rays. For another 7 percent, readers disagreed by 2-3 years. A total of 39 fin rays were discarded because indistinct annuli made accurate aging impossible. The total number of fish with fin rays that yielded acceptable age estimates was 132 in 2013 and 442 in 2014.

Suckers collected from Upper Klamath Lake were nearly all age-0, whereas five age classes of suckers were represented in 2013 and six in 2014 in our Clear Lake Reservoir samples (fig. 11). Of the suckers collected in Upper Klamath Lake in 2014, five were age-1 and one was age-2. All these fish had a genetic probability of assignment as Lost River suckers $\leq 0.307$, indicating they were more like shortnose suckers than Lost River suckers. All other suckers collected in 2013 and 2014 from Upper Klamath Lake were estimated to be age-0. Ages of suckers captured from Clear Lake Reservoir in 2013 ranged from 0 to 4 years and were dominated by age-2 fish. In 2014, suckers captured from Clear Lake Reservoir ranged from age- 1 to age- 6 and were dominated by age- 3 fish. Only three suckers collected from Clear Lake Reservoir in 2014 had genetic probabilities of being Lost River suckers that exceeded 0.03 (prob $[\mathrm{LRS}]=0.25,0.50$, and 0.99). These fish were 2 and 3 years old.

\section{Triglyceride Content}

Triglyceride analyses of wild suckers not identified to species in 2013 provided baseline range values. The triglyceride content measured for 1 of 12 suckers from Upper Klamath Lake in 2013 was suspiciously low $(0.42 \mathrm{mg} / \mathrm{g})$ given that it had a mid-range condition factor and, therefore, was not considered valid data and removed from further consideration. Triglyceride content for all other Upper Klamath Lake suckers captured in 2013 ranged from 1.42 to $26.36 \mathrm{mg} / \mathrm{g}$, with an average \pm SD of 9.41 $\pm 7.75 \mathrm{mg} / \mathrm{g}(\mathrm{n}=11)$. The one Clear Lake Reservoir sucker analyzed in $2013 \mathrm{had} 13.00 \mathrm{mg}$ of triglycerides per gram body weight.

Triglyceride content of suckers collected in 2014 varied with age in Clear Lake Reservoir, but not by species in Upper Klamath Lake or by dates of collection in either lake. A qualitative comparison of suckers with a prob [LRS] $\leq 0.03$ captured in Clear Lake Reservoir in 2014 indicated that age-3 suckers tended to have more milligrams of triglycerides per gram body weight $(10.91 \pm 10.06 \mathrm{mg} / \mathrm{g}$, $\mathrm{n}=13)$ than age-1 $(4.22 \pm 2.69 \mathrm{mg} / \mathrm{g}, \mathrm{n}=10)$ or age- 2 suckers $(4.95 \pm 5.54 \mathrm{mg} / \mathrm{g}, \mathrm{n}=13)$ (fig. 12). The two age- 4 and one age -5 shortnose suckers from Clear Lake Reservoir that were analyzed for triglycerides had triglyceride content that was similar to that for age- 1 and age- 2 and less than the average for age- 3 shortnose suckers. Triglyceride content in Upper Klamath Lake suckers ranged from 2.53 to $32.27 \mathrm{mg} / \mathrm{g}$ $(10.14 \pm 4.61 \mathrm{mg} / \mathrm{g}, \mathrm{n}=98)$ and was not strongly correlated with probability of species assignment (coefficient of determination $\left.\left[R^{2}\right]=0.06\right)$ or date of capture $\left(R^{2}=0.01\right)$. For suckers from Clear Lake Reservoir, triglyceride content was not correlated with date of capture (all age classes combined, $\left.R^{2}=0.08\right)$. 

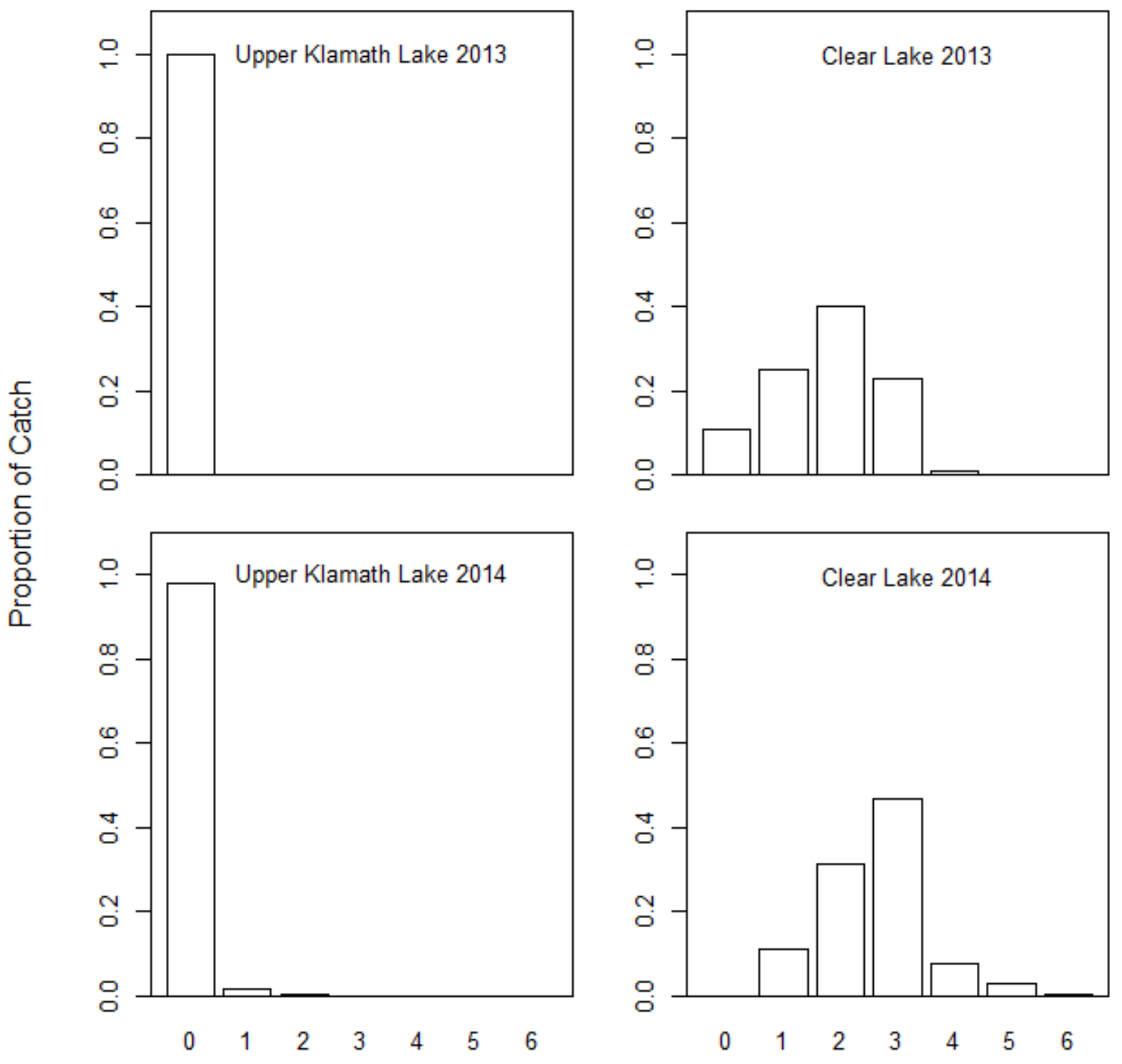

Number of Annuli

Figure 11. The proportion of annual sucker catches with zero to six annuli on fin rays in Upper Klamath Lake, Oregon, and Clear Lake Reservoir, California, 2012-14. All species are combined in these plots. Both meristic and genetic methods of species identification indicated that both species were present in Upper Klamath Lake in both years. However, all age-1 or older suckers collected from Upper Klamath Lake had a genetic probability of assignment as Lost River suckers $\leq 0.307$, indicating that they were more like shortnose suckers than Lost River suckers. Only four fish from Clear Lake Reservoir were identified to species in 2013 and all were identified as shortnose suckers. Of 181 suckers collected from Clear Lake Reservoir in 2014, 178 had a genetic probability of $\leq 0.03$ of being a Lost River sucker. 


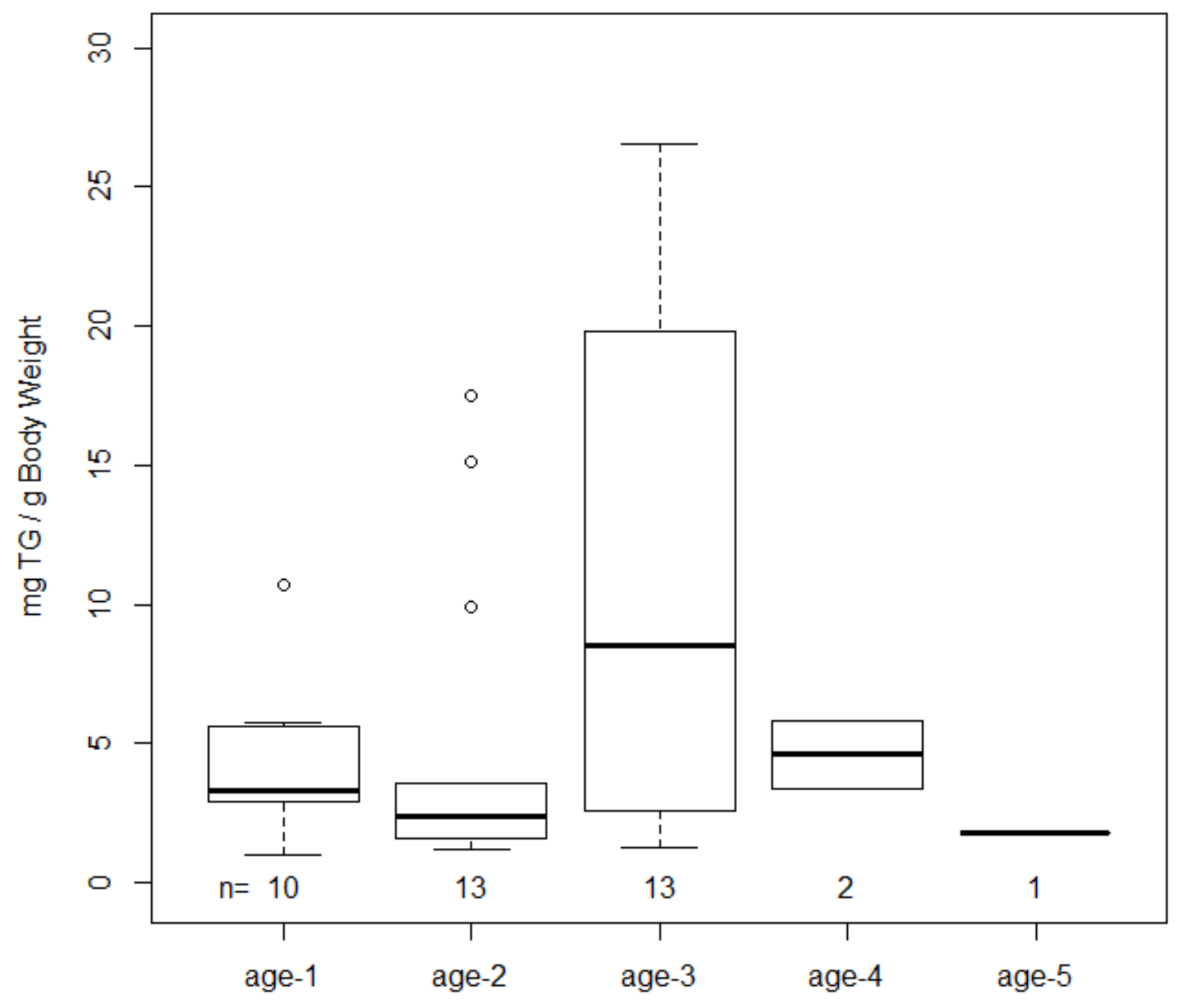

Figure 12. Milligrams of triglyceride content per grams of body weight (mg TG/g Body Weight) by age of suckers collected from Clear Lake Reservoir, California, 2014. Suckers included in this plot all had a genetic probability of species assignment of Lost River sucker of less than or equal to 0.03 , indicating they were more likely to be a shortnose sucker. Ages were estimated based on the number of annuli on sections of fin rays. Median values for each age group are indicated by a thick black line, boxes show the middle 50 percent of data, whiskers indicate the 90th and 10th percentiles, and dots indicate the most extreme values. Sample sizes are given above the $x$-axis line. 


\section{Sucker Length and Apparent Growth}

There was a large amount of variation in length at age among cohorts of suckers captured in Clear Lake Reservoir (fig. 13). Nevertheless, age-0 suckers captured between mid-July and midSeptember in Clear Lake Reservoir in the 2 years for which we have data (2012 and 2013) were nearly all larger than all those captured in Upper Klamath Lake in 2013 and 2014 (fig. 14). There was no difference in the mean $(\mathrm{p}=0.48, \mathrm{df}=16)$ or distribution of age- 0 sucker (all species combined) lengths $(p=0.64, D=0.23)$ within Upper Klamath Lake between 2013 and 2014 (fig. 14). There was a significant $(p<0.001)$ effect of prob [LRS] on growth of age-0 suckers in Upper Klamath Lake in 2014. Suckers with the lowest prob [LRS] grew (mean \pm standard error [SE]) $0.43 \pm 0.03 \mathrm{~mm} /$ day and suckers with the highest prob [LRS] grew (mean SE) $7.9 \pm 1.26 \times$ as fast (fig. 15).

Fulton's condition factor varied between lakes and years within species. Shortnose suckers had higher mean condition factors in 2014 in Upper Klamath Lake than in Clear Lake Reservoir ( $p<0.001$; table 2. Condition factor for shortnose suckers also varied within Clear Lake Reservoir between 2012 and $2014(\mathrm{p}<0.001)$. Although small sample sizes precluded other meaningful statistical analyses, it is noteworthy that all but 2 of 45 Lost River suckers captured in Upper Klamath Lake in either year had higher condition factors than all 9 Lost River suckers captured in Clear Lake Reservoir in 2012.

Table 2. Fulton's condition factor by sucker species, lake, and year.

[The mean and standard deviation (SD) for condition factor and number of fish (n) are given for each sucker species, year, and lake combination. No standard deviation (denoted as -) could be derived for shortnose suckers from Clear Lake Reservoir in 2013 because the sample included only one fish. T-tests and Kolomogorov-Smirnov tests were used to compare the mean and distribution (respectively) between shortnose suckers in Clear Lake Reservoir in 2012 and 2014 and between shortnose suckers in 2014 between lakes. All tests indicated differences $(p<0.001)$. Statistical comparisons among other groups were not conducted because of small sample sizes]

\begin{tabular}{cccccc}
\hline \multirow{2}{*}{ Species } & Lake & Year & n & \multicolumn{2}{c}{ Fulton's Condition Factor } \\
\cline { 5 - 6 } & & & & mean & SD \\
\hline Lost River sucker & Clear Lake Reservoir & 2012 & 9 & 1.05 & 0.10 \\
Lost River sucker & Upper Klamath Lake & 2013 & 4 & 1.42 & 0.11 \\
Lost River sucker & Upper Klamath Lake & 2014 & 41 & 1.47 & 0.14 \\
Shortnose sucker & Clear Lake Reservoir & 2012 & 70 & 1.18 & 0.16 \\
Shortnose sucker & Clear Lake Reservoir & 2013 & 1 & 1.69 & - \\
Shortnose sucker & Clear Lake Reservoir & 2014 & 26 & 1.56 & 0.11 \\
Shortnose sucker & Upper Klamath Lake & 2013 & 8 & 1.67 & 0.12 \\
Shortnose sucker & Upper Klamath Lake & 2014 & 36 & 1.74 & 0.18 \\
\hline
\end{tabular}




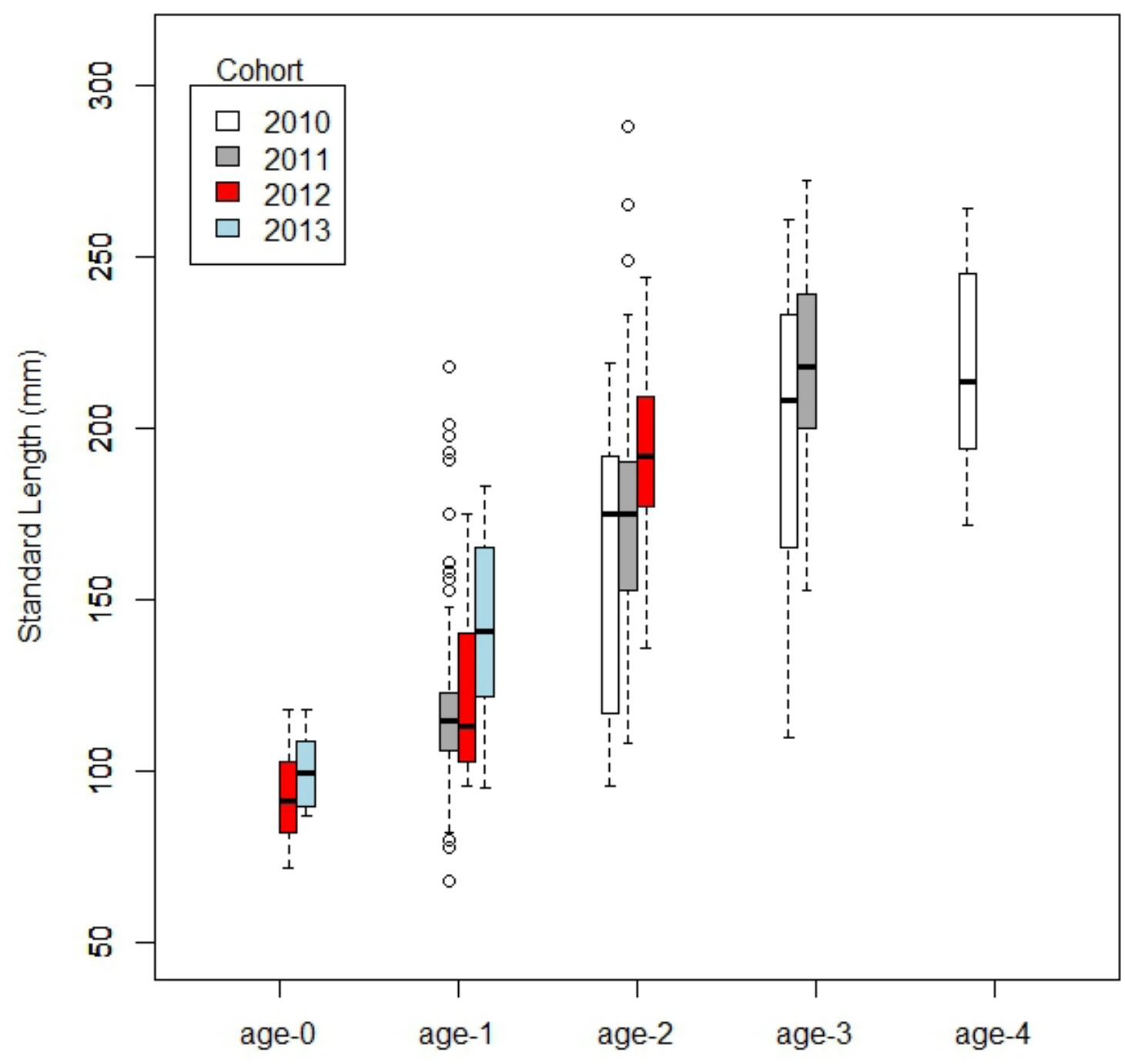

Figure 13. Standard length of suckers $(\mathrm{mm})$ by age and cohort, from data collected from Clear Lake Reservoir, California, 2010-2013. Median values for each age group are indicated by a thick black line, boxes show the middle 50 percent of data, whiskers indicate the 90th and 10th percentiles, and dots indicate the most extreme values. 


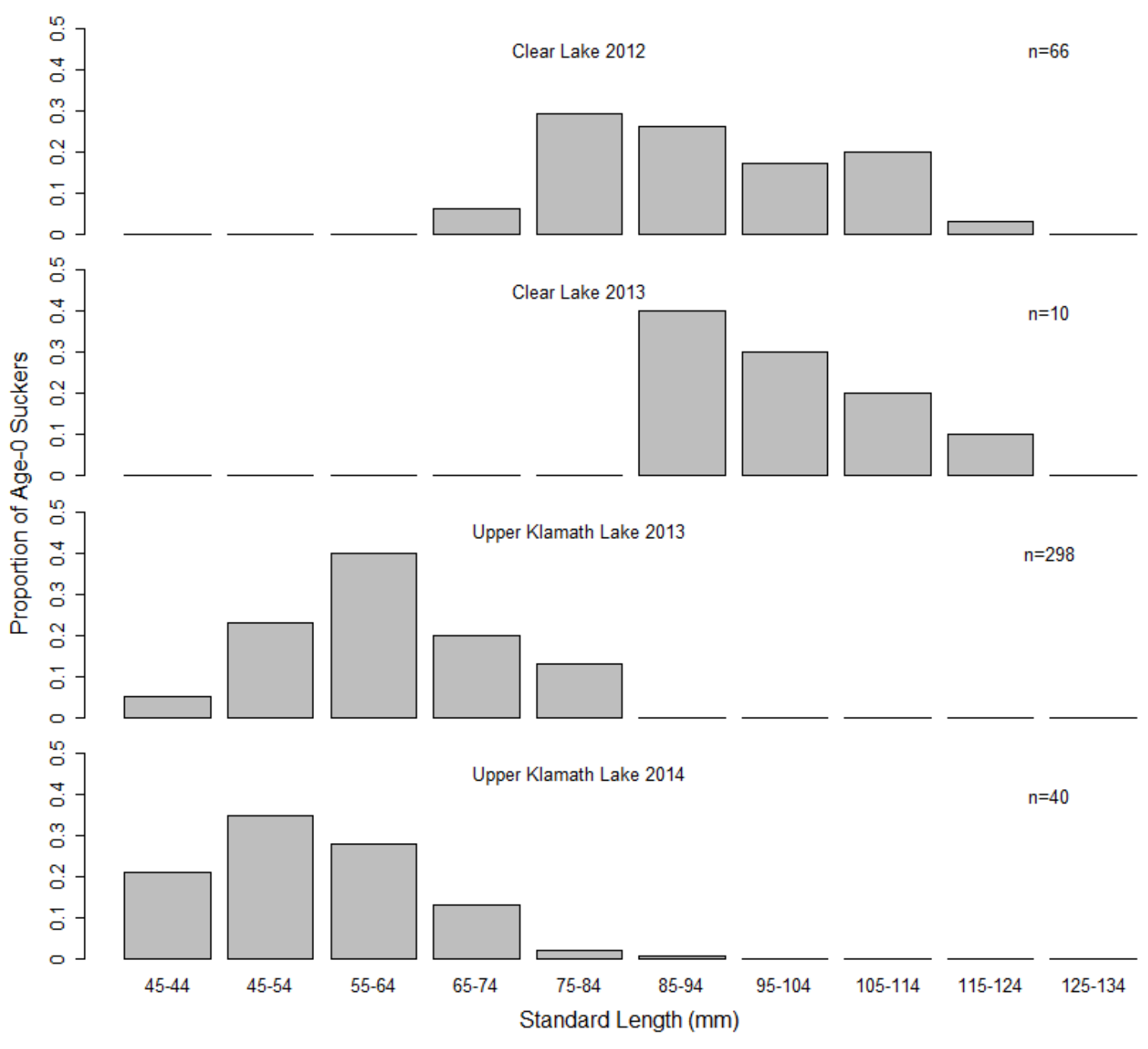

Figure 14. Standard length distribution for age-0 suckers captured in Clear Lake Reservoir, California, 2012-13, and in Upper Klamath Lake, Oregon, 2013-14. Sample size (n) is given in each plot. 


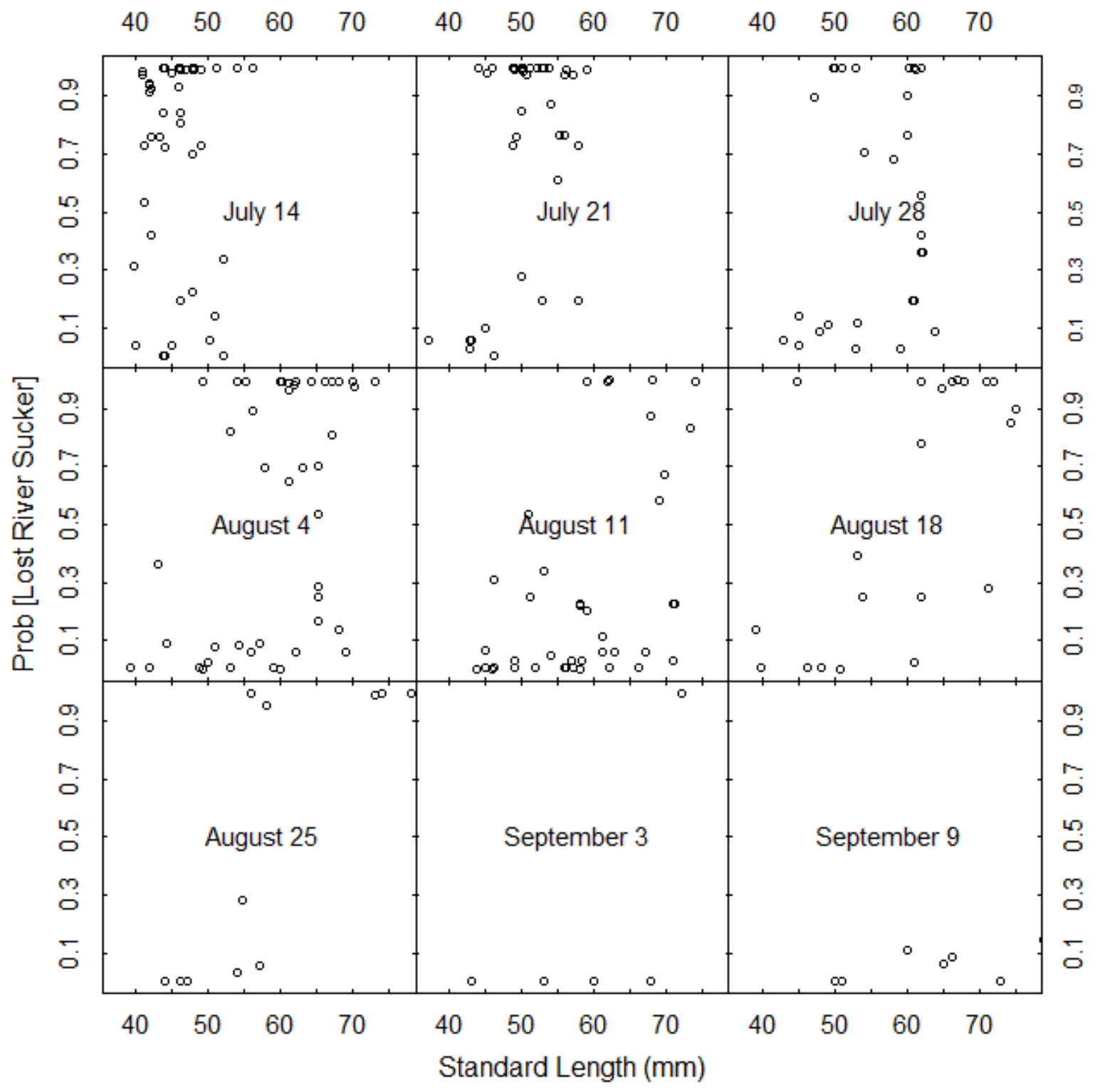

Figure 15. Genetic probability of species assignment as a Lost River sucker (Prob[Lost River Sucker]) by standard length and week, for suckers collected from Upper Klamath Lake, Oregon, 2014. Each subplot shows data for the week that started on the date shown. 


\section{Results of 2014 Field Examinations}

None of the 181 suckers examined from Clear Lake Reservoir had deformed opercula, whereas 8 percent of age-0 suckers from Upper Klamath Lake had this deformity. Suckers in Upper Klamath Lake that had the deformity had a higher average prob [LRS] $(0.75 \pm 0.37)$ than suckers that did not have the deformity (prob $[\mathrm{LRS}]=0.0 .47 \pm 0.46 ; \mathrm{p}<0.001, \mathrm{df}=23$ ). The deformity was bilateral in 74 percent of affected suckers.

A total of 16 percent of suckers collected from Upper Klamath Lake and none from Clear Lake Reservoir had petechial hemorrhages of the skin. The average prob [LRS] was similar for suckers with and without this affliction $(\mathrm{p}=0.15)$. Although petechial hemorrhages of the skin were observed on suckers from Upper Klamath Lake throughout the sampling period, 30 percent of all observations of this condition occurred during the week of August 5, although no more than 16 percent were observed in any other single week.

External field observations detected black-spot-forming parasites in the skin of 15 percent of suckers from Upper Klamath Lake and none from Clear Lake Reservoir. Although black spots were noted throughout the sampling period, the prevalence of these parasites was somewhat greater between July 15 and August 14, 2014, than earlier or later in the sampling season.

Lernaea spp. were more prevalent and present in higher numbers on suckers from Clear Lake Reservoir compared to Upper Klamath Lake. Most suckers from Clear Lake Reservoir (81 percent) had one or more attached Lernaea spp. Although 90 percent of these fish had 5 or fewer Lernaea spp., as many as 12 per fish were observed on suckers from Clear Lake Reservoir. In Upper Klamath Lake, 10 percent of suckers had Lernaea spp. attached and none of these had more than 4 Lernaea spp. per fish.

Visceral fat was categorized as high for around 32 percent, moderate for around 53 percent, and very low for around 15 percent of suckers examined from both lakes. Both taxa were represented in the Upper Klamath Lake sample in all three categories and there was no difference in the median prob [LRS] $(\mathrm{p}=0.53, \mathrm{df}=2)$ for individuals in each visceral fat category. Macroscopic observations of fish sampled from Clear Lake Reservoir indicated that visceral fat was minimal to excessive in fish sampled from mid-July through the week of August 14, 2014, but not present or minimal in all fish sampled after that. In Upper Klamath Lake, the percentage of fish that had no observable visceral fat was zero in most weeks prior to August 17, 2014, but increased to between 20 and 50 percent of fish after that. However, the number of fish examined each week from Upper Klamath Lake that had high amounts of visceral fat was never less than 14 percent or greater than 50 percent. 
Field necropsies indicated variation in liver color and numerous other abnormalities in small numbers of fish captured in each lake. Pale pink or tan colored livers were observed in 37 percent of suckers from Clear Lake Reservoir and 51 percent of suckers from Upper Klamath Lake. The average $( \pm \mathrm{SD})$ prob [LRS] was similar between fish in Upper Klamath Lake with $(0.51 \pm 0.41)$ and without $(0.59$ \pm 0.41 ) off-colored livers ( $\mathrm{p}=0.46$ ). Off-colored livers were pale, pink, or tan color but did not have nodules or grainy textures. Except for two suckers from Upper Klamath Lake and one from Clear Lake Reservoir with pale gills, gill condition appeared normal in all suckers examined. Other conditions, each noted on less than 3 percent of suckers, included deformed fins, hemorrhages in the eyes, exophthalmos of the eyes, missing eyes, scale loss, scarring on the body, deformed caudal peduncles, open wounds associated with lamprey bites, apparent bruising on the caudal peduncle, and deformed vertebrae seen in x-rays. On a single sucker with a prob [LRS] of 0.003 captured from Clear Lake Reservoir, a cyst was observed near the gills under the opercula.

\section{Histopathology}

In most wild and all hatchery fish sampled during 2013, histological changes including inflammation and necrosis were minimal and considered to be normal according to the criteria of Foott and others (2000). Focal, mild inflammation and necrosis were only observed in the anterior kidney of one Lost River sucker sampled from Upper Klamath Lake (data not shown).

In tissues examined in 2014, inflammation was focal and minimal or mild, except when associated with parasites where it was severe. Inflammation was characterized by the presence of several inflammatory cell types including lymphocytes, macrophages, polymorphonuclear cells, and eosinophilic granular cells. The presence of rodlet cells in areas of inflammation also was noted. Necrosis was minimal to mild and characterized as individual cell (apoptotic) necrosis or coagulative necrosis.

Inflammatory cell infiltration around liver blood vessels and bile ducts (perivascular and peribiliary cuffing; fig. 16) or foci of inflammatory cells infiltrating the hepatocellular tissue (liver parenchyma) was observed in 75 percent of shortnose suckers collected from Clear Lake Reservoir during 2014; it was present in 50 percent of fish sampled from July 30 through early August and in all fish sampled from early August through mid-September (table 3). Livers from 20 percent of suckers sampled from Upper Klamath Lake in 2014 showed cuffing or parenchymal inflammation (table 3). Most affected fish (83 percent) in Upper Klamath Lake were shortnose suckers. Focal, mild inflammation, but no cuffing, also was observed in the liver parenchyma of one Lost River sucker from Upper Klamath Lake. No liver abnormalities were observed in suckers collected from Upper Klamath Lake from July 15 to July 17 when microcystin concentrations were low. Inflammation prevalence increased slightly from 22 percent in early August to 40 percent in late August through mid-September, during periods of increasing and decreasing microcystin concentrations, respectively (table 3 ). 


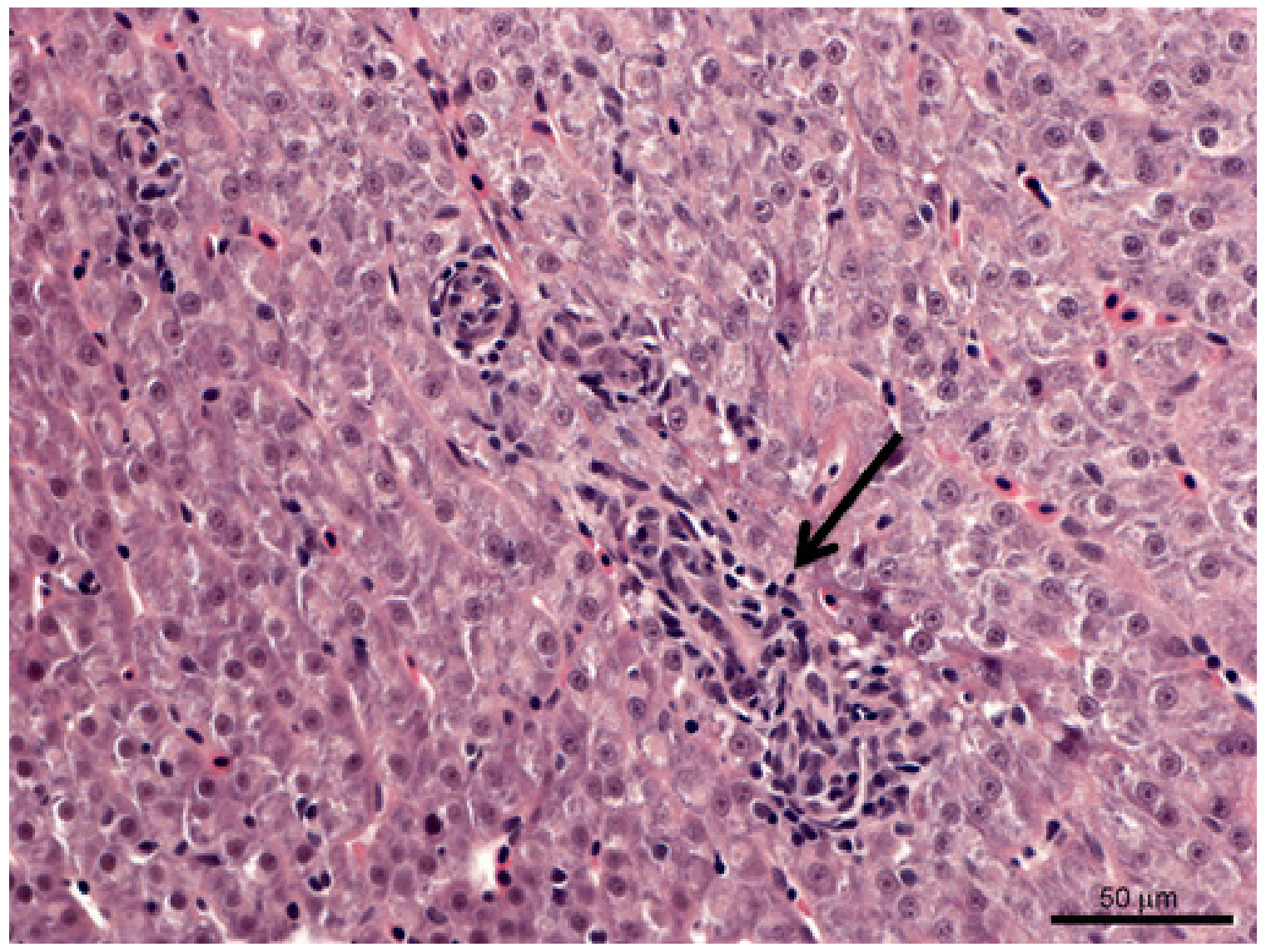

Figure 16. Inflammatory cell infiltration surrounding a bile duct (peribiliary cuffing) in the liver of a sucker sampled from Upper Klamath Lake, Oregon.

Hepatocellular lipid vacuolation was characterized by hepatocyte cytoplasm containing occasional presumptive lipid vacuoles (low levels) or consisting almost entirely of round, well-defined vacuoles (high levels). The presence of lipid vacuolation was not correlated with liver color $(\mathrm{p}=0.56)$. In 2013, no hepatocyte vacuolation was observed in any shortnose suckers sampled from Clear Lake Reservoir (table 3). In comparison, variable amounts of hepatocyte vacuolation (from low to high) were observed in 45 percent of suckers collected from Upper Klamath Lake and 50 percent of hatchery Lost River suckers examined in 2013 (table 3). In 2014, no hepatocellular vacuolation was observed in 75 percent of fish sampled from Clear Lake Reservoir and about 50 percent from Upper Klamath Lake. Among fish identified to species in 2014 from Upper Klamath Lake, hepatocyte vacuolation prevalence was the same for shortnose and Lost River suckers, with no vacuolation observed in about 30 percent of the fish and in low levels in 20 percent of the fish. Low vacuolation levels were observed in 50 percent of Clear Lake Reservoir shortnose suckers sampled from late July through early August 2014, but no vacuolation was present in any fish examined from early August through mid-September. None to low levels of hepatocellular vacuolation were present in approximately equal numbers of fish sampled from Upper Klamath Lake from mid-July through mid-September, 2014 (table 3). 
In 2013, the levels of hepatocellular glycogen were high in all hatchery-reared fish and in most wild fish ( $\geq 67$ percent) sampled from both lakes (table 3 ). The level of hepatocyte glycogen was not correlated with liver color $(\mathrm{p}=0.12)$. No glycogen was observed in livers from one Klamath largescale and one shortnose sucker (morphological identifications) from Clear Lake Reservoir, and two Lost River suckers and a shortnose sucker captured from Upper Klamath Lake in 2013. In 2014, the levels of hepatocellular glycogen were high in 60 percent of suckers collected from Clear Lake Reservoir and 62 percent collected from Upper Klamath Lake (table 4). In fish sampled from Upper Klamath Lake, glycogen levels were high in 66 percent of shortnose and 77 percent of Lost River suckers. Hepatocyte glycogen storage varied by date of capture (table 4). In fish sampled from Clear Lake Reservoir, high hepatocellular glycogen levels were observed in all fish sampled from late July through early August, but in only 20 percent in fish sampled from early August through mid-September when low glycogen levels were observed in 70 percent of fish. Glycogen levels were high in fish sampled from Upper Klamath Lake in mid-July (90 percent) and early August (89 percent), during low and increasing microcystin concentrations, respectively. Hepatocellular glycogen levels were low in 80 percent of fish sampled from Upper Klamath Lake in mid-August through mid-September during decreasing microcystin concentrations.

In 2013, histological changes in gill tissue were limited to hyperplasia in 33 percent of suckers collected from Clear Lake Reservoir and 8 percent of suckers sampled from Upper Klamath Lake (table 4). In 2014, gill histological changes included inflammation, hyperplasia, and hypertrophy in interlamellar tissue, and were observed in 5 percent of Clear Lake Reservoir suckers and 13 percent of suckers sampled from Upper Klamath Lake. Hyperplastic and hypertrophic gill tissue was observed in 40 percent of suckers collected in late August 2014 from Upper Klamath Lake during periods of decreasing microcystin concentrations, low un-ionized ammonia concentrations, moderate $\mathrm{pH}$, and relatively high DO concentrations (table 4).

Trichodinid protozoan parasites occurred on the gills of some of the fish sampled from both lakes in 2013, but no parasites were observed on the gills of any hatchery fish (table 4). Trichodinids were observed on 67 percent of fish sampled from Clear Lake Reservoir and 25 percent of fish from Upper Klamath Lake. Of the trichodinid-infested fish sampled from Upper Klamath Lake, two were Lost River suckers and the other was a shortnose sucker. The mean number of trichodinids per field at $200 \times$ magnification was less than 1 in fish sampled from Clear Lake Reservoir and greater than 8 per field in fish from Upper Klamath Lake. In 2014, trichodinids were observed on the gills of 20 percent of suckers sampled from Clear Lake Reservoir and 40 percent of suckers sampled from Upper Klamath Lake (table 4). Among fish identified to species from Upper Klamath Lake, the prevalence of trichodinids was approximately equal between shortnose (45 percent) and Lost River (55 percent) suckers. No trichodinids were observed on suckers collected from Upper Klamath Lake in July. The prevalence of fish with trichodinids increased to 50 percent in early August to 70 percent in late August through mid-September (table 4). The presence of trichodinid parasites was not associated with gill tissue inflammation, necrosis, hyperplasia, or hypertrophy. 
Metazoan parasites and associated host response were observed during histopathological examination of fish from both lakes in 2014. Focal, severe inflammation surrounding Lernaea spp. attachment sites were observed in the skin and skeletal muscle of fish from Upper Klamath Lake and Clear Lake Reservoir (table 5). A melanin-encysted trematode metacercaria was present in the skeletal muscle of one shortnose sucker on which the black spots had been observed during collection. In another shortnose sucker from Upper Klamath Lake, a digenean (trematode) metacercaria was observed in the skeletal muscle, but no melanin encystment was seen. Examination of skin and skeletal muscle indicated no hemorrhaging or lesions in fish where petechial hemorrhaging was observed macroscopically.

Other incidences of host response to parasites included multifocal, severe inflammation associated with acanthocephalan parasites (thorny-headed worms) in the gastrointestinal tracts of 30 percent of fish captured from Clear Lake Reservoir in 2014 (table 5). Mild, focal granulomatous inflammation and coagulative necrosis surrounded a metacercaria located in the ventriculobulbar valve of the heart of one fish sampled from Upper Klamath Lake in August 2014 (data not shown).

Eosinophilic hyaline droplets in kidney tubule epithelial cells were observed in three hatcheryreared suckers, a shortnose sucker from Upper Klamath Lake, and one Klamath largescale and one shortnose sucker from Clear Lake Reservoir, all captured in September 2013 (data not shown). In fish sampled during 2014, hyaline droplets were observed in the kidney tubules of only one fish (a shortnose sucker) sampled from Upper Klamath Lake. In suckers collected from Clear Lake Reservoir in 2014, hyaline material was present in most fish (data not shown).

\section{Unbound Microcystin}

No unbound microcystin was detected in any of the 15 trunk or 15 viscera samples. Replicate analyses of samples run for quality control also were free of unbound microcystins. 
Table 3. Number of fish positive by histopathological examination for liver inflammation, hepatocyte cytoplasmic vacuolation, and cytoplasmic glycogen staining among suckers sampled from Clear Lake Reservoir, California, and Upper Klamath Lake, Oregon, during (a) 2013 , and (b) 2014.

[n, total number of fish examined]

(a) 2013

\begin{tabular}{|c|c|c|c|c|c|c|c|c|c|c|}
\hline \multirow[b]{2}{*}{ Location } & \multirow[b]{2}{*}{ Sample dates } & \multirow[b]{2}{*}{$\mathrm{n}$} & \multicolumn{2}{|c|}{ Inflammation } & \multicolumn{3}{|c|}{ Vacuolation } & \multicolumn{3}{|c|}{ Glycogen } \\
\hline & & & $\begin{array}{l}\text { Perivascular/ } \\
\text { peribiliary }\end{array}$ & Parenchyma & None & Low & High & None & Low & High \\
\hline $\begin{array}{l}\text { Clear Lake Reserv } \\
\text { Southern shore }\end{array}$ & Aug. 6 and Sept.10 & 4 & 0 & 0 & 4 & 0 & 0 & 1 & 1 & 2 \\
\hline Western shore & Sept. 24 and 26 & 2 & 0 & 0 & 2 & 0 & 0 & 0 & 0 & 2 \\
\hline $\begin{array}{l}\text { Upper Klamath La } \\
\text { Fish Banks }\end{array}$ & $\begin{array}{l}\text { Aug. } 15-29, \\
\text { Sept. } 4 \text { and } 5\end{array}$ & 11 & 0 & 0 & 6 & 4 & 1 & 3 & 0 & 8 \\
\hline Hatchery & Nov. 6 & 10 & 0 & 0 & 5 & 4 & 1 & 0 & 0 & 10 \\
\hline
\end{tabular}

(b) 2014

\begin{tabular}{|c|c|c|c|c|c|c|c|c|c|c|}
\hline \multirow[b]{2}{*}{ Location } & \multirow[b]{2}{*}{ Sample dates } & \multirow[b]{2}{*}{$\mathrm{n}$} & \multicolumn{2}{|c|}{ Inflammation } & \multicolumn{3}{|c|}{ Vacuolation } & \multicolumn{3}{|c|}{ Glycogen } \\
\hline & & & $\begin{array}{l}\text { Perivascularl } \\
\text { peribiliary }\end{array}$ & Parenchyma & None & Low & High & None & Low & High \\
\hline \multirow{3}{*}{$\begin{array}{l}\text { Clear Lake Reservoir } \\
\text { Southern shore }\end{array}$} & & & & & & & & & & \\
\hline & Jul. 30-Aug. 7 & 10 & 5 & 1 & 5 & 5 & 0 & 0 & 0 & 10 \\
\hline & Aug. 7-Sept.10 & 10 & 10 & 5 & 10 & 0 & 0 & 1 & 7 & 2 \\
\hline \multicolumn{11}{|l|}{ Upper Klamath Lake } \\
\hline Fish Banks $^{1}$ & Jul. 15-17 & 10 & 0 & 0 & 5 & 5 & 0 & 0 & 1 & 9 \\
\hline Fish Banks & Aug. 5-7 & 9 & 2 & 0 & 5 & 4 & 0 & 0 & 1 & 8 \\
\hline Fish Banks $^{2}$ & Aug. 26-Sept. 11 & 10 & 3 & 3 & 4 & 6 & 0 & 1 & 8 & 1 \\
\hline
\end{tabular}

${ }^{1}$ Low microcystin concentrations.

${ }^{2}$ Decreasing microcystin concentrations. 
Table 4. Number of fish positive by histopathological examination of gill samples for inflammation, necrosis, hyperplasia, hypertrophy, and trichodinid protozoan parasites among suckers sampled from Clear Lake Reservoir, California, and Upper Klamath Lake, Oregon, during (a) 2013, and (b) 2014.

[n, total number of fish examined; <, less than; >, greater than]

(a) 2013

\begin{tabular}{|c|c|c|c|c|c|c|c|}
\hline Location & Sample dates & $\mathrm{n}$ & Inflammation & Hyperplasia & Hypertrophy & Trichodinids & $\begin{array}{l}\text { Trichodinid intensity } \\
\text { (number per 200x field) }\end{array}$ \\
\hline \multicolumn{8}{|c|}{ Clear Lake Reservoir } \\
\hline Southern shore & Aug. 6 and Sept. 10 & 4 & 0 & 2 & 0 & 3 & $<1$ \\
\hline Western shore & Sept. 24 and 26 & 2 & 0 & 0 & 0 & 1 & $<1$ \\
\hline \multicolumn{8}{|c|}{ Upper Klamath Lake } \\
\hline Fish Banks & Aug. 15-29, & & & & & & \\
\hline & Sept. 4 and 5 & 12 & 0 & 1 & 0 & 3 & $>8$ \\
\hline Hatchery & Nov. 6 & 10 & 0 & 0 & 0 & 0 & 0 \\
\hline
\end{tabular}

\begin{tabular}{|c|c|c|c|c|c|c|c|}
\hline Location & Sample dates & $\mathrm{n}$ & Inflammation & Hyperplasia & Hypertrophy & Trichodinids & $\begin{array}{l}\text { Trichodinid intensity } \\
\text { (number per } 200 \times \text { field) }\end{array}$ \\
\hline \multirow[t]{2}{*}{$\begin{array}{l}\text { Clear Lake Reservoir } \\
\text { Southern shore }\end{array}$} & Jul. 30-Aug. 7 & 10 & 0 & 0 & 0 & 1 & $>30$ \\
\hline & Aug. 7-Sept.10 & 10 & 1 & 1 & 0 & 3 & $<5$ \\
\hline $\begin{array}{l}\text { Upper Klamath Lake } \\
\text { Fish Banks }\end{array}$ & Jul. 15-17 & 10 & 0 & 0 & 0 & 0 & 0 \\
\hline Fish Banks $^{2}$ & Aug. 5-7 & 10 & 0 & 0 & 0 & 5 & $<5$ \\
\hline Fish Banks ${ }^{3}$ & Aug. 26-Sept. 11 & 10 & 14 & 4 & 4 & 7 & $<5$ \\
\hline
\end{tabular}

${ }^{1}$ Low microcystin concentrations.

${ }^{2}$ Increasing microcystin concentrations.

${ }^{3}$ Decreasing microcystin concentrations.

${ }^{4}$ Mild, focal apoptotic necrosis also was observed in this fish. 
Table 5. Occurrence of histological response and host response to parasites observed microscopically in suckers sampled from Clear Lake Reservoir, California, and Upper Klamath Lake, Oregon, 2014.

[The number of fish in which a host response to parasites was observed and the parasite identifications are shown in parentheses beneath each histological response category. Abbreviations: n, total number of fish examined; AC, acanthocephalan; LN, copepod Lernaea spp.; MT, digenean (trematode) metacercaria]

\begin{tabular}{|c|c|c|c|c|c|c|}
\hline \multirow{2}{*}{ Location } & \multirow{2}{*}{ Sample dates } & \multirow{2}{*}{$\mathrm{n}$} & \multirow{2}{*}{$\begin{array}{c}\text { Gastrointestinal tract } \\
\text { Inflammation }\end{array}$} & \multirow{2}{*}{$\begin{array}{c}\text { Pancreas/ } \\
\text { Interpancreatic tissue } \\
\text { Inflammation }\end{array}$} & \multicolumn{2}{|c|}{ Skin and skeletal muscle } \\
\hline & & & & & Inflammation & Necrosis \\
\hline \multirow[t]{2}{*}{$\begin{array}{l}\text { Clear Lake Reservoir } \\
\text { Southern shore }\end{array}$} & Jul. 30-Aug. 6 & 10 & $\begin{array}{c}5 \\
(2, \mathrm{AC})\end{array}$ & 0 & $\begin{array}{c}1 \\
(1, \mathrm{LN})\end{array}$ & $\begin{array}{c}1 \\
(1, \mathrm{LN})\end{array}$ \\
\hline & Aug. 7-Sept.10 & 10 & $\begin{array}{r}{ }_{4} 1 \\
(\mathrm{AC})\end{array}$ & $\begin{array}{c}3 \\
(1, \mathrm{AC})\end{array}$ & $\begin{array}{c}6 \\
(6, \mathrm{LN})\end{array}$ & $\begin{array}{c}5 \\
(5, \mathrm{LN})\end{array}$ \\
\hline $\begin{array}{l}\text { Upper Klamath Lake } \\
\text { Fish Banks }{ }^{1}\end{array}$ & Jul. $15-17$ & 10 & 0 & 0 & $\begin{array}{r}1 \\
(\mathrm{MT})\end{array}$ & 0 \\
\hline Fish Banks ${ }^{2}$ & Aug. 5-7 & 10 & 0 & 0 & 3 & 0 \\
\hline Fish Banks ${ }^{3}$ & Aug. 26-Sept. 11 & 10 & 0 & 0 & $\begin{array}{c}4 \\
(2, \mathrm{LN})\end{array}$ & 2 \\
\hline
\end{tabular}

${ }^{1}$ Low microcystin concentrations.

${ }^{2}$ Increasing microcystin concentrations.

${ }^{3}$ Decreasing microcystin concentrations.

${ }^{4}$ Host response to the acanthocephalan included fibrosis and extended into the interpancreatic connective tissue. 


\section{Discussion}

\section{Survival and Apparent Growth of Lost River and Shortnose Suckers}

Age composition indicated that suckers survived for several years in Clear Lake Reservoir but few survived longer than 1 year in Upper Klamath Lake. This conclusion was based on catching no age-1 or older suckers in 2013 and only six in 2014 in Upper Klamath Lake, compared to 82 ( 0.98 per net) age-1 or older suckers in 2013 and 181 ( 0.56 per net) in 2014 in Clear Lake Reservoir. Although catch rates for age-1 or older suckers in Upper Klamath Lake were extremely low compared to Clear Lake Reservoir, they were typical for Upper Klamath Lake. Previously reported catch rates for age-1 suckers in Upper Klamath Lake from mid-July to mid-September are nearly always in the range of 1-3 suckers for every 100 trap nets fished (Burdick and others, 2009; Bottcher and Burdick, 2010; Burdick and Brown, 2010; Burdick and VanderKooi, 2010). The exception was following a high production year in 2006, when catch rates for age-1 suckers averaged around one sucker per 10 nets fished (Burdick and others, 2009).

Our conclusion that the difference in catch rates between age classes in Upper Klamath Lake is owing to mortality rather than emigration or a reduction in sample efficiency is based on several well-supported assumptions. We presumed that the disappearance of suckers from our nets was not related to emigration from the study area based on previous research that indicated that juvenile suckers do not migrate out of Upper Klamath Lake or from near to offshore habitats within Upper Klamath Lake between June and August (Hendrixson and others, 2007). We presumed that capture efficiency did not decrease to near zero for age-1 or older suckers in Upper Klamath Lake, based on catches of age-1 and older suckers in Clear Lake Reservoir in the same gear type at the same time of year. We assumed that our catches within a limited area in each lake accurately represented age distributions of populations. This assumption is supported by prior catch data in each lake, in which there did not appear to be strong age-based spatial distribution patterns from mid-July to mid-September (Burdick and Brown, 2010; Burdick and Hewitt, 2012). Nevertheless, there may be some spatial patterning for age-1 and older suckers but not for age-0 suckers in response to low DO concentrations (Bottcher and Burdick, 2010). Age-1 suckers are not captured in hypoxic areas, whereas age-0 suckers are caught throughout Upper Klamath Lake as long as conditions are not anoxic (Bottcher and Burdick, 2010). Dissolved-oxygen concentrations as measured at mid-north were nearly always greater than 4 $\mathrm{mg} / \mathrm{L}$ and were higher even inside a mesocosm located at Fish Banks in 2014 (data not shown). Therefore, we do not suspect that our sample area in Upper Klamath Lake was avoided by age-1 or older suckers.

Juvenile Lost River suckers were nearly absent from our catches in Clear Lake Reservoir, despite annual captures of Lost River suckers in the autumn and spawning adult Lost River suckers in the spring. Lost River suckers make up a smaller proportion of the adult sucker population in Clear Lake Reservoir than in Upper Klamath Lake each year. For example, adult Lost River suckers decreased from 27 percent to 10 percent of September and October catches in Clear Lake Reservoir from 2005 to 2009 (Hewitt and Hayes, 2013). In contrast, Lost River suckers made up less than 1 percent of all juvenile suckers captured. Scoppettone and others (1995) collected sucker larvae presumed to be Lost River suckers out-migrating from Willow 
Creek in a 1993 survey. Assuming that Lost River suckers that ascend Willow Creek to spawn still successfully produce larvae, our results indicate this species either emigrates from the lake, dies, or both before reaching the minimum size of fish that can be captured in our nets (about 35 $\mathrm{mm} \mathrm{SL}$ ).

First-year growth for suckers appears to be much greater for Clear Lake Reservoir suckers compared to Upper Klamath Lake suckers. The 10 suckers collected from Clear Lake Reservoir in 2013 that had no fin ray annuli were on average \pm SD nearly twice as large (99.9 $\pm 11.0 \mathrm{~mm}$ SL) as suckers from Upper Klamath Lake in either year with no fin ray annuli $(2013=60.8 \pm 9.7 \mathrm{~mm} \mathrm{SL} ; 2014=54.5 \pm 10.4 \mathrm{~mm} \mathrm{SL})$. Suckers collected from Clear Lake Reservoir in $2012(n=66)$ that had no fin ray annuli were on average $92.8 \pm 12.8 \mathrm{~mm}$ SL (Burdick and Rasmussen, 2013). A small amount of disagreement among ages was documented and disagreement about age- 0 suckers was uncommon, indicating that age assignment was at least consistent. Therefore, our data most likely indicates that suckers in Clear Lake Reservoir are actually larger by July of their first year than those in Upper Klamath Lake. Spawning migrations occur about 5 weeks earlier in Clear Lake Reservoir than in Upper Klamath Lake and may allow Clear Lake Reservoir suckers to get a head start on growth even though water temperatures during those 5 weeks are much colder than in tributaries to Upper Klamath Lake (Hewitt and Hayes, 2013; Hewitt and others, 2014).

\section{Fish Health and Condition}

Suckers collected from Upper Klamath Lake did not show signs of widespread or severe disease or parasite problems despite results of this study and previous research that suggest nearly all of them die within the first year of life. The lack of severely diseased fish could be explained, at least in part, by the passive gear used in our study that may be biased toward healthy fish that are active enough to swim into our nets. Although other gears have been tried, it is difficult to obtain reasonable sample sizes of suckers using active methods. The conditions we observed in a small proportion of fish may in fact be present in a larger proportion of the population, especially if these conditions reduce the swimming activity of suckers. Another explanation for the lack of sick fish in our catches may be that the conditions that cause the highest annual mortality do not occur during our sampling period or are owing to predation. Despite the lack of moribund fish in our catches, we did observe a number of tissue abnormalities in suckers by macroscopic examination, histopathology, or both, and some of these abnormalities may provide clues to causes of differential survival of suckers between the two lakes.

Opercular deformities, identified in suckers from Upper Klamath Lake but not Clear Lake Reservoir, may provide a clue to the apparent lack of survival of young suckers in Upper Klamath Lake. This deformity is considered non-lethal for hatchery-reared fish (Beraldo and others, 2003). However, Barkstedt and others (2015) found that that the prevalence of opercular deformities on three species of wild-caught catostomids decreased with age, and concluded that mortality related to the deformity was the likely cause. Deformed opercula have been noted in suckers as small as $16 \mathrm{~mm}$ SL from Upper Klamath Lake and the Williamson and Sprague Rivers, but the prevalence in larvae and small juveniles has not been quantified (U.S. Geological Survey, unpub. data, 2014). Determining the prevalence of this deformity in suckers throughout their first year of life could provide information about the life stage at which this deformity first appears. Such information could be useful in determining if deformed opercles are associated with mortality. 
Opercular deformities may lower resistance to oxygen stress and predispose fish to infections by bacteria, parasites, and fungi (Galeotti and others, 2000; Beraldo and others, 2003), or reduce predator avoidance. These deformities have numerous potential causes including low pH, inbreeding, hybridization (Winemiller and Taylor, 1982; Tringali and others, 2001), nutritional deficiency (Chávez de Martínez, 1990; Lall, 2002), heavy metals, pesticides, high egg incubation temperatures (Boglione and others, 2013) and parasites (Quist and others, 2007). The $\mathrm{pH}$ was neutral to high rather than low in Upper Klamath Lake during the 2 years of our study, indicating that was not the cause. Nutrition related to skeletal deformities in fish includes too much or too little dietary bioavailable phosphorus $(\mathrm{P})$ relative to calcium uptake, and deficiencies in vitamins $C$ and D, phospholipids, unsaturated fatty acids, or magnesium (Lall, 2002; Cahu and others, 2003). Deformed opercula also have been noted at low rates in hatchery-reared Lost River suckers, which may indicate that the causes are genetic, temperature related, or nutritional (U.S. Geological Survey, unpub. observations, 2014). Additionally, opercular deformities are observed in redband trout (Oncorhynchus mykiss newberrii) and the federally listed threatened bull trout (Salvelinus confluentus) in tributaries to Upper Klamath Lake including the upper Sprague River drainage, Wood River drainage, and Threemile Creek (N. Banish, U.S. Fish and Wildlife Service, oral commun., 2014; W. Tinniswood, Oregon Department of Fish and Wildlife Service, oral commun., 2014). However, it is not clear that the same factors that cause the deformity in these trout cause deformity in suckers.

Minimal to mild changes including hyperplasia, hypertrophy, inflammation and necrosis in the gills of suckers collected in August and September from Upper Klamath Lake could have resulted from exposure to a broad range of irritants including both infectious and noninfectious agents (Lafayette, 1975; Ferguson, 1989). However, microcystins and ammonia were unlikely the cause of gill changes. For example, gill necrosis in common carp was documented after they were exposed to $1,700 \mu \mathrm{g} / \mathrm{mL}$ of dissolved microcystin toxin (Carbis and others, 1996). In our study, dissolved microcystin concentrations that peaked at only $4.5 \mu \mathrm{g} / \mathrm{L}$ in Upper Klamath Lake were not likely high enough to cause gill tissue necrosis.

Elevated un-ionized ammonia concentrations do not explain minimal to mild hyperplasia, hypertrophy, inflammation, and necrosis of gills of suckers collected in August and September from Upper Klamath Lake. Mean gill lamellar thickness has been reported to increase in Lost River suckers exposed to un-ionized ammonia concentrations greater than or equal to $0.20 \mathrm{mg} / \mathrm{L}$, (Lease and others, 2003). However, un-ionized ammonia concentrations only exceeded 0.20 $\mathrm{mg} / \mathrm{L}$ on two sample dates in mid-July and early August 2013 and on two sample dates in midJuly 2014 when hyperplasia and hypertrophy were not observed. Other histological signs of ammonia toxicity were not observed, such as increased mucosal cells and infiltration of white blood cells into lymphatic spaces (Lease and others, 2003). Even at the most extreme values measured in this study, un-ionized ammonia concentrations were not in the ranges that are known to cause most structural changes in gill tissues (Lease and others, 2003), and were much less than the 24- to 96 -hour mean $\mathrm{LC}_{50}$ for juvenile Lost River $(\geq 0.78 \mathrm{mg} / \mathrm{L})$ or shortnose $(\geq 0.53$ $\mathrm{mg} / \mathrm{L}$ ) suckers (Saiki and others, 1999).

Interlamellar hyperplasia observed may have been a normal tissue reaction of fish when DO concentrations were relatively high and water temperatures were relatively low. Gill tissues of cyprinids and some other fishes have been shown to undergo "remodeling" to reduce the gill respiratory surface area when oxygen availability is high or oxygen needs are low (Nilsson and others, 2012; Dhillon and others, 2013). Remodeling also serves to increase gill surface area when oxygen availability is low and is associated with more hypoxia-tolerant fishes (Dhillon and 
others, 2013). If shortnose and Lost River suckers do indeed have the ability to remodel their gills to adapt to low DO conditions, this ability may explain their tolerance to very low DO concentrations. Other possible advantages to gill remodeling may include reduction of uptake of toxic substances and reduction of infection (Nilsson and others, 2012) during periods of relatively high DO concentrations. Gill remodeling also may have associated energetic costs or result in other consequences that are not yet known. It is not known how rapidly or frequently fish can remodel gills. Laboratory trials are required to evaluate the potential effects of diel changes in DO concentrations in Upper Klamath Lake on long-term ability to remodel gills.

Petechial hemorrhaging, observed in the skin of Upper Klamath Lake suckers in 2014, can have various causes, including infectious agents or abrasion (Ferguson, 1989). Although there was not a strong temporal pattern in the occurrence of this condition, it was somewhat more common in early August, when un-ionized ammonia concentrations were low, $\mathrm{pH}$ was decreasing, and dissolved microcystins were not detected, but water temperatures were relatively high.

Because of the documented effects of microcystin on fish liver tissue (Malbrouck and Kestemont, 2006), this tissue was one of the primary targets of histopathological analysis in our study. Perivascular cuffing in the liver similar to that observed in fish in our study is one of the clinical signs noted in net-pen disease of Atlantic salmon (Salmo salar), which is thought to be associated with microcystin exposure (Kent and others, 1996). Therefore, perivascular/peribiliary cuffing or parenchymal foci of inflammatory cells in livers, observed in 3 of 10 suckers from Upper Klamath Lake after mid-August, could be interpreted as responses to microcystin, except that this same condition was observed in all 10 sucker livers examined from Clear Lake Reservoir where no microcystin was detected. Cuffing primarily was observed in livers of shortnose suckers, the dominant sucker species in Clear Lake Reservoir. Perivascular/peribiliary cuffing represents an inflammatory/immune response that can have various causes, and generally is not considered an indicator of a specific etiology (Lang and others 2006). Cuffing has been associated with infectious agents (Kent and Myers, 2000; Iwanowicz and others, 2006; Grésoviac and others, 2007) as well as exposure to certain toxicants (Boorman and others, 1997).

Despite very high concentrations of microcystin in the particulate fraction and moderate concentrations in the dissolved fraction of water samples from Upper Klamath Lake in 2014, suckers had few signs, if any, of microcystin toxicity. Concentrations of microcystins in particulate matter exceeded lethal digestible limits for common carp (6.6 $\mu \mathrm{g} / \mathrm{g}$ body weight) from August 13 to September 8 (Fischer and Dietrich, 2000). However, we did not detect free microcystin in viscera or muscle, which may indicate that suckers did not consume the toxin. Alternatively, we may not have detected toxin that was consumed because microcystin forms covalent bonds with proteins very rapidly and may have been present but undetectable with the methods we used (Dyble and others, 2011).

Although the temporal change in liver glycogen levels in Upper Klamath Lake in 2014 is consistent with a hypothesis that microcystin caused this hepatocellular change, other evidence contradicts this hypothesis. Dietary exposure to microcystin can interrupt blood and hepatocyte glycogen regulation and deplete glycogen storage (Malbrouck and Kestemont, 2006; Acuna and others, 2012). However, certain other signs of microcystin toxicity in liver tissue including hepatocyte shrinkage and increased nuclear/cytoplasmic ratio (Carbis and others, 1996) were not observed. Glycogen levels also were low in suckers from Clear Lake Reservoir where microcystin was not detected. 
Hypoxia-tolerant fishes tend to have high levels of hepatic glycogen storage (Dhillon and others, 2013). Reduction or depletion of liver glycogen that occurs during prolonged hypoxia or anoxia in such fishes indicates that it is an important glucose energy source during periods of oxygen depletion (Zhou and others, 2000). For example, the crucian carp (Carassius carassius) uses enormous stores of liver glycogen to survive extended periods of anoxia in winter. During anoxia, glucose is the only available cellular fuel, and the crucian carp uses glycolytic metabolism, with production of ethanol that is released into the water, to avoid lactate selfpoisoning (Nilsson and Renshaw, 2004). The temporal decrease in hepatic glycogen in Upper Klamath Lake in 2014 could be interpreted as a result of prolonged hypoxia, except that glycogen depletion also was observed in Clear Lake Reservoir where DO concentrations were greater than or equal to $5.7 \mathrm{mg} / \mathrm{L}$.

When energy intake exceeds the needs for metabolism, growth, swimming exertion, reproduction, and other activity, a fish tends to store a part of the excess energy as glycogen and (or) lipid in the cytoplasm of hepatocytes (Wolf and others, 2015). Therefore, high glycogen levels in fish sampled from Upper Klamath Lake in mid-July and early August 2014 seem to indicate a period of increased feeding and storage of excess glycogen. Lower glycogen levels in late August and early September 2014 seem to indicate a period of either decreased feeding or increased energy demands. Alternatively, the type and amount of hepatic energy stores also can vary by species, age, sex, reproductive phase, season, or effects of inflammatory or toxic processes (Wolf and others, 2015) and may not necessarily represent nutritional status or energy expenditure. We did not detect a decrease in triglyceride content throughout the sampling period, which may indicate suckers metabolized glycogen prior to triglycerides. When deprived of food, many fishes metabolize glycogen prior to triglycerides (Garvey and Chipps, 2012), but several migratory species and at least one cyprinid (Cyprinus carpio) metabolize triglycerides prior to glycogen (Enes and others, 2009). As with our findings, hatchery-reared Lost River suckers held in a mesocosm in Upper Klamath Lake in 2014 also maintained fairly constant levels of wholebody triglycerides (U.S. Geological Survey unpub. data, 2014). In contrast to our findings, Foott and others (2012) noted that triglyceride content seemed to decrease between August and October for sentinel Lost River suckers held in Upper Klamath Lake in 2011. The difference among study results may indicate annual variability in seasonal energy storage, or may be a spurious result owing to small sample sizes in the two captive fish studies.

Triglyceride densities measured in this study were variable and within the range of values reported for suckers and other species (Foott and others, 2005; Bennett and others, 2007). Higher triglyceride content in suckers from Upper Klamath Lake compared to suckers from Clear Lake Reservoir in 2014 may be a result of differences in species, age classes, individuals, or environments (Post and Parkinson, 2001; Bennett and others, 2007). The ranges and means of triglyceride content of Upper Klamath Lake suckers sampled in our study in both years were greater than reported for wild-caught suckers from Upper Klamath Lake in 2004 (3.1-16.1 mg/g) (Foott and Stone, 2005). Higher values in our study may be a result of annual variation in lake conditions, prey availability, or prey quality. Alternatively, the Fish Banks area in Upper Klamath Lake where we captured suckers may have a higher quantity and quality of prey than areas sampled in previous studies. We found no correlation between triglyceride content and species or date of capture; therefore, these variables are unlikely to explain the differences between studies. 
Hyaline droplets observed in kidney tubular epithelial cells of juvenile suckers from both lakes in our study have previously been described in both adult and juvenile suckers from Upper Klamath Lake, but this may not indicate a specific etiology. The droplets are a sign of hyaline degeneration, which is owing to lipoprotein accumulation in the epithelial cell phagolysosomes (Foott and others, 2013). Lost River suckers form hyaline droplets in the proximal tubules in the kidneys when exposed to un-ionized ammonia concentrations at $0.22 \mathrm{mg} / \mathrm{L}$ or greater for 62 hours (Foott and others, 2000), but fish with hyaline droplets in our study were collected when un-ionized ammonia concentrations were low. Although hyaline droplets also can form as an initial response to hypoxia (Tervonen and others, 2006), the observations of this condition were asynchronous with low DO concentrations in our study. Finally, hyaline droplets can occur in the epithelium of kidney tubules of fish that have had no exposure to toxins or pathogens and otherwise appear healthy (Ferguson, 1989; Wolf and others, 2015).

Several parasites identified on suckers in this study could potentially harm the fish. The ectoparasitic copepod Lernaea spp. can cause severe inflammatory lesions and ulceration at the attachment site, which can provide portals of entry for opportunistic bacterial pathogens (Berry and others, 1991). However, inflammation owing to these parasites, although severe, was limited to the area directly around the attachment site. Two internal parasites, one from each lake, may be of concern given that they were associated with significant inflammation. It is unknown whether the presence of the single metacercaria encysted in a heart valve of a single sucker from Upper Klamath Lake could affect blood flow and cardiac function, but heavy infections of digenean metacercariae encysted in the bulbus arteriosus of some fish species have been associated with blockage of blood flow, decreased cardiac function and swimming performance, and decreased ability to survive under conditions of reduced DO concentrations (Coleman, 1993; Coleman and Travis, 1998; Hicks and Steele, 2013). The spined retractable proboscis of an acanthocephalan, such as those observed in one sucker from Clear Lake Reservoir, typically is embedded in the gut wall and can cause severe inflammation (Bruno and others, 2006). Our use of histological samples for detection of these parasites was not ideal, as histopathology is not as sensitive as examination of wet tissues for quantification of parasites (Ferguson and others, 2011). Nevertheless, histopathology is valuable for evaluating host response to parasites, and for detecting pathogens or other abnormalities that cannot be observed by gross examination (Kent and others, 2013).

Although trichodinid parasites were present on gills of 70 percent of suckers collected from Upper Klamath Lake in August and September 2014, they were not associated with cellular changes or damage. The number of trichodinids per field may have been biased slightly high because only one gill arch, instead of two, was sectioned. Trichodinids are ciliated protozoans that primarily are ectocommensals when present in low numbers and use fish as a substrate for attachment while feeding on waterborne particles and bacteria, as well as detritus and particles from the fish surface (Lom and Dyková, 1992; Bruno and others, 2006).

\section{Fish Assemblages}

Potential fish predators to juvenile suckers were present in both lakes. Brown bullhead, which feed extensively on fish (Moyle, 2002), were on average about $3 \times$ larger than suckers captured at the same time in Upper Klamath Lake. This species accounted for nearly all the fish we sampled with a gape large enough to consume a juvenile sucker captured from Upper Klamath Lake from July to September. Although we only detected brown bullheads in Upper Klamath Lake, they also have been detected in the lower reaches of Willow Creek and, therefore, 
presumably are present in Clear Lake Reservoir (Koch and others, 1975). Nevertheless, this species was one of the least common in our catches. Therefore, predation by brown bullhead is unlikely to be a primary cause of recruitment failure. Non-native and piscivorous yellow perch were one of the three most common species in Upper Klamath Lake in our study and may have fed on larvae and early-stage juvenile suckers. Non-native and piscivorous Sacramento perch were the most common fish species in Clear Lake Reservoir and were large enough to prey on sucker larvae and smaller age-0 suckers.

The fish community in Clear Lake Reservoir seems to have changed since Koch and others (1975) surveyed it in 1975. Chub (Gila spp.) were co-dominant with Sacramento perch, together making up 80 percent of the catch in the 1975 Clear Lake Reservoir sampling. A small number of suckers and trout also were detected in 1975, but fathead minnows were not. In contrast, our catches were co-dominated by Sacramento perch and fathead minnows. Chubs and marbled sculpin made up a total of 8 percent of 2014 catches.

The large biomass of non-native fathead minnows in Upper Klamath Lake has led to several hypotheses about their effect on sucker survival. Although fathead minnows were a dominant species in both lakes, their biomass was much greater in Upper Klamath Lake. Because fathead minnows eat larval suckers when presented with no other prey, it has been suggested that this species may be able to cause significant larval sucker mortality (Markle and Dunsmoor, 2007). The Markle and Dunsmoor (2007) hypothesis could be true if seasonal fathead minnow biomass does not synchronize with March or April larval sucker outmigration in Clear Lake Reservoir. Fathead minnows also may facilitate the spread of pathogens or parasites to which suckers are highly susceptible (Kent and Peterson, 2015). The Kent and Peterson (2015) hypothesis also would be supported if the pathogens or parasites causing high sucker mortality in Upper Klamath Lake are not present in Clear Lake Reservoir fathead minnows.

\section{Conclusions}

Suckers in Clear Lake Reservoir, California, have lower triglyceride content than suckers in Upper Klamath Lake, Oregon. Although this finding is complicated by different age classes in each lake, it is consistent with observations of lower primary production and less benthic prey in Clear Lake Reservoir. Suckers from both lakes indicate similar patterns of glycogen storage early in the summer that was depleted by late August and early September 2014. The combined growth and energy storage information that we report may indicate that it is not a lack of prey that limits sucker growth in Upper Klamath Lake, but some other environmental or genetic factor.

The main causes of recruitment failure may be owing to factors not examined in our study. Neither gross nor histological examination of suckers revealed obvious etiologies of high mortality. Because of the lack of health-related abnormalities, we cannot rule out the possibility that most mortality occurs prior to when we begin to catch suckers in mid-July. For example, predation by the large number of non-native and piscivorous fishes in Upper Klamath Lake may substantially reduce larval or small juvenile survival. Passive integrated transponder tags inserted into live age- 1 and adult suckers in both lakes have been detected on bird colonies, indicating that bird predation is a factor in sucker survival. However, it is not clear if bird predation can cause near complete recruitment failure, or why suckers would survive better in Clear Lake Reservoir than in Upper Klamath Lake. 
When viewed in combination, multiple observations may provide clues to causes of sucker mortality. For example, petechial hemorrhaging and deformed opercula may both be symptoms of toxin exposure. However, the lack of association between liver necrosis and high microcystin concentrations, and lack of unbound microcystin in tissues seem to eliminate this toxin as a potential cause for mass juvenile sucker mortality. Another possibility is that the combination of deformed opercula and slow growth may indicate a nutritional deficiency such as insufficient essential fatty acid availability or and imbalance in the ratio of calcium to phosphorus. Alternatively hybridization between Lost River and shortnose suckers may cause deformed opercula. Finally, the range in gill conditions from seemingly normal to hyperplastic and hypertrophic, combined with the apparent slow growth in Upper Klamath Lake, may indicate a high energetic demand of gill remodeling in response to diel variation in dissolved oxygen concentrations.

\section{References Cited}

Acuna, S., Baxa, D., and Teh, S., 2012, Sublethal dietary effects of microcystin producing Microcystis on threadfin shad, Dorosoma petenense: Toxicon, v. 60, p. 1,191-1, 202.

Adams, S.M., Brown, A.M., and Goede, R.W., 1993, A quantitative health assessment index for rapid evaluation of fish condition in the field: Transactions of the American Fisheries Society, v. 122, p 63-73.

Banish, N.P., Adams, B.J., Shivley, R.S., Mazur, M.M, Beauchamp, D.A., and Wood, T.M., 2009, Distribution and habitat associations of radio-tagged Lost River and shortnose suckers in Upper Klamath Lake, Oregon: Transactions of the American Fisheries Society, v. 138, p.153-168. Barkstedt, J.M., Farrington, M.A., and Kennedy, J.L., 2015, Frequency of opercular deformities in age-0 native catostomids in the San Juan River from 1998 to 2012:

Albuquerque, New Mexico, American Southwest Ichthyological Researchers, L.L.C., 38 p.

Bennett, P.M., Weber, L.P., and Janz, D.M., 2007, Comparison of chloroform-methanolextracted and solvent-free triglyceride determinations in four fish species: Journal of Aquatic Animal Health, v. 19, p. 179-185.

Beraldo, P., Pinosa, M., Tibaldi, E., and Canavese, B., 2003, Abnormalities of the operculum in gilthead sea bream (Sparus aurata)—Morphological description: Aquaculture, v. 220, p. 89-99.

Berry, C.R., Jr., Babey, G.J., and Shrader, Terry, 1991, Effect of Lernaea cyprinacea (Crustacea: Copepoda) on stocked rainbow trout (Oncorhynchus mykiss): Journal of Wildlife Diseases, v. 27, p. 206-213.

Boorman, G.A., Botts, S., Bunton, T.E., Fournie, J.W. , Harshbarger, J.C., Hawkins, W.E., Hinton, D.E., Jokinen, M.P. Okihiro, M.S., and Wolfe, M.J., 1997, Diagnostic criteria for degenerative, inflammatory, proliferative nonneoplastic and neoplastic liver lesions in medaka (Oryzias latipes) - Consensus of a national toxicology program pathology working group: Environmental Toxicologic Pathology, v. 25, p. 202-210.

Boglione, C., Gisbert, E., Gavaia, P., Witten, P.E., Moren, M., Fontagne, S., and Koumoundours, G., 2013, Skeletal anomalies in reared European fish larvae and juveniles-Part 2-Main typologies, occurrences and causative factors: Reviews in Aquaculture, v. 5, no. 1, p. S121S167. 
Bottcher, J.L., and Burdick, S.M., 2010, Temporal and spatial distribution of endangered juvenile Lost River and shortnose suckers in relation to environmental variables in Upper Klamath Lake, Oregon-2009 annual data summary: U.S. Geological Survey Open-File Report 2010-1261. [Also available at http://pubs.usgs.gov/of/2010/1261/.]

Bradbury, J.P., Colman, S.M., and Dean, W.E., 2004, Limnological and climatic environments at Upper Klamath Lake, Oregon, during the past 45,000 years: Journal of Paleolimnology, v.31, p. $167-188$.

Bruno, D.W., Nowak, B., and Elliott, D.G., 2006, Guide to the identification of fish protozoan and metazoan parasites in stained tissue sections: Diseases of Aquatic Organisms, v. 70, p. 136.

Burdick, S.M., Anderson, G.O., and VanderKooi, S.P., 2009, Spring and summer habitat use by endangered juvenile Lost River and shortnose suckers in Upper Klamath Lake, Oregon-2007 annual report: U.S. Geological Survey Open-File Report 2009-1043, 56 p. [Also available at http://pubs.usgs.gov/of/2009/1043/.]

Burdick, S.M., and Brown, D.T., 2010, Distribution and condition of larval and juvenile Lost River and shortnose suckers in the Williamson River Delta restoration project and Upper Klamath Lake, Oregon - 2009 annual data summary: U.S. Geological Survey Open-File Report 2010-1216. [Also available at http://pubs.usgs.gov/of/2010/1216/.]

Burdick, S.M., and Hewitt, D.A., 2012, Distribution and condition of young-of-year Lost River and shortnose suckers in the Williamson River Delta restoration project and Upper Klamath Lake, Oregon, 2008-10: U.S. Geological Survey Open-File Report 2012-1098. [Also available at http://pubs.usgs.gov/of/2012/1098/.]

Burdick, S.M., Hewitt, D.A., Rasmussen, J.E., Hayes, B.S., Janney, E.C., and Harris, A.C., 2015. Effects of lake surface elevation on shoreline-spawning of Lost River suckers: North American Journal of Fisheries Management, v. 35, no. 3, p. 478-490.

Burdick, S.M., Ottinger, C., Brown, D.T., VanderKooi, S.P., Robertson, L., and Iwanowicz, D., 2009, Distribution, health, and development of larval and juvenile Lost River and shortnose suckers in the Williamson River Delta restoration project and Upper Klamath Lake, Oregon2008 annual data summary: U.S. Geological Survey Open-File Report 2009-1287, 76 p. [Also available at $h t t p: / / p u b s . u s g s . g o v / o f / 2009 / 1287 /$.

Burdick, S.M., and Rasmussen, J., 2013, Age and condition of juvenile catostomids in Clear Lake Reservoir, California: U.S. Geological Survey Open-File Report 2013-1188. [Also available at http://pubs.usgs.gov/of/2013/1188/.]

Burdick, S.M., and VanderKooi, S.P., 2010, Spring and summer habitat use by endangered juvenile Lost River and shortnose suckers in Upper Klamath Lake, Oregon-2008 annual report: U.S. Geological Survey Open-File Report 2010-1051. [Also available at http://pubs.usgs.gov/of/2010/1051/.]

Buettner, M.E., and Scoppettone, G.G., 1991, Distribution and information on the taxonomic status of the shortnose sucker (Chasmistes brevirostris) and Lost River sucker (Deltistes luxatus) in the Klamath River Basin, California: Reno, Nevada, Seattle National Fishery Research Center, $34 \mathrm{p}$.

Cahu, C., Infante, J. Z., and Takeuchi, T., 2003, Nutritional components affecting skeletal development in fish larvae: Aquaculture, v. 227, p. 245-258.

Carbis, C.R. Rawlin, G.T., Mitchell, G.F., Anderson, J.W. and McCauley, I., 1996, The histopathology of carp, Cyprinus carpio L., exposed to microcystins by gavage, immersion and intraperitoneal administration: Journal of Fish Diseases, v. 19, p. 199-207. 
Carmichael, W., Drapeau, W.C. and Anderson, D.M., 2000, Harvesting of Aphanizomenon flosaquae Ralfs ex Born. and Flah. Var. flos-aquae (Cyanobacteria) from Klamath Lake for human dietary use: Journal of Applied Phycology, v. 12, p. 585-595.

Carson, F.L., 1997, Histotechnology-A self-instructional text (2d ed.): Chicago, ASCP Press, $304 \mathrm{p}$.

Carson, F.L., Martin, J.H., and Lynn, J.A., 1973, Formalin fixation for electron microscopy-A re-evaluation: American Journal of Clinical Pathology, v. 59, p. 365-373.

Castleberry, D.T., and Cech Jr., J.J., 1993, Critical thermal maxima and oxygen minima of five fishes from the Upper Klamath Basin: California Fish and Game, v. 78, no. 4, p.145-152.

Chávez de Martinez, M.C., 1990, Vitamin C requirements of the Mexican native cichlid Cichlasoma urophthalmus (Gunther): Aquaculture, v. 86, p. 409-416.

Coleman, F.C., 1993, Morphological and physiological consequences of parasites encysted in the bulbus arteriosus of an estuarine fish, the sheepshead minnow, Cyprinodon variegatus: Journal of Parasitology, v. 79, no. 2, p. 247-254.

Coleman, F.C., and J. Travis, 1998, Phenology of recruitment and infection patterns of Ascocotyle pachycystis, a digenean parasite in the sheepshead minnow, Cyprinodon variegatus: Environmental Biology of Fishes, v. 51, p. 87-96.

Cooperman, M., and Markle, D.F., 2003, Rapid out-migration of Lost River and shortnose sucker larvae from in-river spawning beds to in-lake rearing grounds: Transactions of the American Fisheries Society, v. 132, p. 1,138-1,153.

Dyble, J., Grossiaux, D., Landrum, P. Kahsian, D., and Pothoven, S., 2011, A kinetic study of accumulation and elimination of Microcystin-LR in Yellow Perch (Perca flavescens) tissue and implications for human fish consumption: Marine Drugs, v. 9, p. 2553-2571.

Dhillon, R.S., Yao, L. Matey, V., Chen, B., Zhang, A., Cao, Z, Fu, S., Brauner, C., Wang, Y.S., Richards, J.G., 2013, Interspecifci differences in hypoxia-induced gill remodeling in carp:

Physiological and Biochemical Zoology, v. 86, p. 727-739.

Eldridge, D.B., Caldwell Eldridge, S.L., Schenk, L.N., Tanner, D.Q., and Wood, T.M., 2012a, Water-quality data from Upper Klamath and Agency Lakes, Oregon, 2009-10: U.S.

Geological Survey Open-File Report 2012-1142, 32 p. [Also available at http://pubs.usgs.gov/sir/2012/1142/pdf/sir20125069.pdf.]

Eldridge, S.C., Wood, T.M., and Echols, K.R., 2012b, Spatial and temporal dynamics of cyanotoxins and their relation to other water quality variables in Upper Klamath Lake, Oregon, 2007-09: U.S. Geological Survey Scientific Investigations Report 2012-5069, 34 p. [Also available at http://pubs.usgs.gov/sir/2012/5069/pdf/sir20125069.pdf.]

Eldridge, S. C., Wood, T.M., Echols, K.R., and B.R. Topping, 2013, Microcystins, nutrient dynamics, and other environmental factors during blooms on non-microcystin producing Aphanizomenon flos-aquae in Upper Klamath Lake, Oregon, 2009: Lake and Reservoir Management, v. 29, p. 68-81.

Enes, P., Panserat, S., Kaushik, S., Oliva-Teles, A., 2009, Nutritional regulation of hepatic glycose metabolism in fish: Fish Physiology and Biochemistry, v. 35, p. 519-539.

Evanno, G., Regnaut, S., and Goudet, J., 2005, Detecting the number of clusters of individuals using the software STRUCTURE—A simulation study: Molecular Ecology, v. 14, p. 2,6112,620 .

Falter, M.A., and Cech Jr., J.J., 1991, Maximum pH tolerance of three Klamath Basin fishes:

Copeia, v. 1991, no. 4, p. 1,109-1,111.

Ferguson, H.W., 1989, Systemic pathology of fish: Ames, Iowa State University Press, 263 p. 
Ferguson, J.A., Koketsu, W., Ninomiya, I., Rossignol, P.A., Jacobson, K.C., and Kent, M.L., 2011, Mortality of coho salmon (Oncorhynchus kisutch) associated with burdens of multiple parasite species: International Journal for Parasitology, v. 41, no. 9, p. 1,197-1,205.

Fischer, W.J., and Dietrich, D.R., 2000, Pathological and biochemical characterization of microcystin-induced hepatopancreas and kidney damage in carp (Cyprinus carpio):

Toxicology and Applied Pharmacology, v. 164, p. 73-81.

Foott, J.S., Nichols, K., and Harmon, R., 2000, FY2000 investigational report-Histological and hematological evaluation of juvenile Lost River suckers exposed to sub-lethal levels of ammonia: U.S. Fish and Wildlife Service, Anderson, California, 17 p.

Foott, J.S., and Stone, R., 2005, Bio-energetic and histological evaluation of juvenile (0+) sucker fry from Upper Klamath Lake collected in August and September 2004: U.S. Fish and Wildlife Service, Anderson, California, $14 \mathrm{p}$.

Foott, J.S., Stone, R., Jacobs, J., and Wilkens, A., 2014, FY2013 technical report-Juvenile Lost River suckers sentinel survival in Upper Klamath Lake mesocosm netpens (July-October 2013), overwinter survival, and laboratory hypoxic challenge: U.S. Fish and Wildlife Service, Anderson, California, $56 \mathrm{p}$.

Foott, J.S., Stone, R., and Wilkens, A., 2013, FY2012 technical report-Juvenile Lost River sentinel survival in Upper Klamath Lake mesocosm cages (July 2012-March 2013): U.S. Fish and Wildlife Service, Anderson, California, $44 \mathrm{p}$.

Foott, J. S., Stone, R., Wilkens, A., and Rasmussen, J., 2012, Juvenile Lost River survival and energetics in Upper Klamath Lake mesocosm cages-July-December 2011: U.S. Fish and Wildlife Service, Anderson, California, 49 p.

Foott, J.S., Stone, R., Wiseman, E., 2007, FY2006 investigational report-Energetic profiles and mortality response to winter starvation in juvenile suckers (age-0+) from upper Klamath Lake in 2005: U.S. Fish and Wildlife Service, Anderson, California, 35 p.

Galeotti, M., Beraldo, P., de Dominis, D., D’Angelo, L., Ballestrazzi, R., Musetti, R., Pizzolito, S., and Pinosa, M., 2000, A preliminary histological and ultrastructural study of opercular anomalies in gilthead sea bream larvae (Sparus aurata): Fish Physiology and Biochemistry, v. 22, p. 151-157.

Garvey, J.E., and Chipps, S.R., 2012, Diets and energy flow, in Zale, A.V, Parris, D. L., and Sutton, T.M., Fisheries techniques (3rd ed.): Bethesda, Maryland, American Fisheries Society, p. 733-772.

Grésoviac, S.J., Baxa, D.V., Vivarès, C.P., and Hedrick, R.P., 2007, Detection of the intranuclear microsporidium Nucxleospora salmonis in naturally and experimentally exposed Chinook salmon Oncorhynchus tshawytscha by in situ hybridization: Parasitology Research, v. 101, p. 1,257-1,264.

Hendrixson, H.A., Burdick, S.M., VanderKooi, S.P., and Wilkens, A.X., 2007, Near-shore and off-shore habitat use by endangered, juvenile Lost River and shortnose suckers and near-shore water quality, in Upper Klamath Lake, Oregon: U.S. Geological Survey, 109 p.

Hewitt, D.A., and Hayes, B.S., 2013, Monitoring of adult Lost River and shortnose suckers in Clear Lake Reservoir, California, 2008-2010: U.S. Geological Survey Open-File Report 20131301, 18 p. [Also available at $h t t p: / / d x$. doi.org/10.3133/ofr20131301.]

Hewitt, D.A., Janney, E.C., Hayes, B.S., and Harris, A.C., 2014, Demographics and run timing of adult Lost River (Deltistes luxatus) and shortnose (Chasmistes brevirostris) suckers in Upper Klamath Lake, Oregon, 2012: U.S. Geological Survey Open-File Report 2014-1186, 44 p. [Also available at http://dx.doi.org/10.3133/ofr20141186.] 
Hicks, T., and Steele, E., 2013, Histological effects of Ascocotyle tenuicollis (Digenea: Heterophyidae) metacercarial infection on the heart of Fundulus heteroclitus (Teleostei: Cyprinodontidae): Journal of the South Carolina Academy of Science, v. 1, p. 10-18.

Hoy, M.S., and Ostberg. C.O., 2015, Development of 20 TaqMan assays differentiating the endangered shortnose and Lost River suckers: Conservation Genetics Resources, v. 7, no. 3, p. 673-676, doi: 10.1007/s12686-015-0474-y.

Iwanowicz, L.R., Griffin, A.R., Cartwright, D.D., and Blazer, V.S., 2006, Mortality and pathology in brown bullheads Ameiurus nebulosus associated with a spontaneous Edwardsiella ictaluri outbreak under tank culture conditions: Diseases of Aquatic Organisms, v. 70, p. 219-225.

Kent, M., Markle, D.F., Terwilliger, M.R., and Simon, D.C., 2014, Chapter 4-Pathogen investigation of Upper Klamath Lake fishes with emphasis on suckers, in Simon, D.C., Terwilliger, M.R. and Markle, D.F., Larval and juvenile ecology of Upper Klamath Lake suckers-2009-2013: Corvallis, Oregon State University, p. 122-172.

Kent, M.L., Benda, Susan, St.-Hilaire, Sophie, and Schreck, C.B., 2013, Sensitivity and specificity of histology for diagnoses of four common pathogens and detection of nontarget pathogens in adult Chinook salmon (Oncorhynchus tshawytscha) in fresh water: Journal of Veterinary Diagnostic Investigation, v. 25, p. 341-351.

Kent, M.L., Dawe, S.C., St. Hilaire, S., and Andersen, R.J., 1996, Effects of feeding rate, seawater entry, and exposure to natural biota on the severity of net-pen liver disease among pen-reared Atlantic salmon: The Progressive Fish-Culturist, v. 58, p.43-46.

Kent, M.L., and Myers, M.S., 2000, Hepatic lesions in a redstriped rockfish (Sebastes proriger) suggestive of a herpesvirus infection: Diseases of Aquatic Organisms, v. 41, p. 237-239.

Kent, M.L. and Peterson, J., 2015, Parasite associated mortality-Determination of causes of juvenile mortality in Upper Klamath Lake: Proposal to the Klamath Recovery Implementation Team - Science Committee, 2 p.

Kent, M.L., Whitaker, D.J., and Dawe, S.C., 1997, Parvicapsula minibicornis n. sp. (Myxozoa, Myxosporea) from the kidney of sockeye salmon (Oncorhynchus nerka) from British Columbia, Canada: The Journal of Parasitology, v. 83, no. 6, p. 1,153-1,156.

Koch, D.L., Cooper, J.J., Contreras, G.P., and King, V., 1975, Survey of the fishes of the Clear Lake Reservoir Drainage: Reno, Nevada, Center for Water Resources Research, 38 p.

Lafayette, L.E., 1975, Gill lesions in freshwater teleosts, chap. 11 of Ribelin, W.E., and Migaki, George, eds., The pathology of fishes: Madison, University of Wisconsin Press, p. 305-330.

Lall, S.P., 2002, The minerals, in Halver, J.E., and Hardy, R.W., Fish Nutrition (3rd ed.): San Francisco, Academic Press, p. 259-308.

Lang, T., Wosniok, W., Baršiene, J., Broeg, K., Kopecka, J., and Parkkonen, J., 2006, Liver histopathology in Baltic flounder (Platichthys flesus) as indicator of biological effects of contaminants: Marine Pollution Bulletin, v. 53, p. 488-496.

Lease, H.M., Hansen, J.A., Bergman, H.L., and Meyer, J.S., 2003, Structural changes in gills of Lost River suckers exposed to elevated $\mathrm{pH}$ and ammonia concentrations: Comparative Biochemistry and Physiology Part C, v. 134, p. 491-500.

Loftus, M.E., 2001, Assessment of potential water quality stress to fish: Portland, Oregon, R2 Resource Consultants, $65 \mathrm{p}$.

Lom, J., and Dyková, I., 1992, Protozoan parasites of fishes: Developments in Aquaculture and Fisheries Science, v. 26, 319 p. 
Malbrouck, C., and Kestemont, P., 2006, Effects of microcystins on fish: Environmental Toxicology and Chemistry, v. 25, p. 72-86.

Markle, D.F., Cavalluzzi, M.R., and Simon, D.C., 2005, Morphology and taxonomy of Klamath Basin suckers (Catostomidae): Western North American Naturalist, v. 65, p. 473-489.

Markle, D.F., and Clauson, K., 2006, Ontogenetic and habitat-related changes in diet of late larval and juvenile suckers (Catostomidae) in Upper Klamath Lake, Oregon: Western North American Naturalist, v. 66, no. 4, p. 492-501.

Markle, D.F., and Cooperman, M.S., 2002, Relationships between Lost River and shortnose sucker biology and management of Upper Klamath Lake, in Braunworth, W.S., Jr., Welch, T., and Hathaway, R., Water allocation in the Klamath Reclamation Project, 2001-An assessment of natural resource, economic, social, and institutional issues with a focus on the Upper Klamath Basin: Corvallis, Oregon State University, p. 93-117.

Markle, D.F. and Dunsmoor, L.K., 2007, Effects of habitat columns and fathead minnow introduction on larval survival of two endangered sucker species in Upper Klamath Lake, Oregon: Transactions of the American Fisheries Society, v. 136, p. 567-579.

Martin, B.A., Hewitt, D.A., and Ellsworth, C.M., 2013, Effects of Chiloquin Dam on spawning distribution and larval emigration of Lost River, shortnose, and Klamath largescale suckers in the Williamson and Sprague Rivers, Oregon: U.S. Geological Survey Open-File Report 20131039, 28p. [Also available at http://pubs.usgs.gov/of/2013/1039/pdf/ofr20131039.pdf.]

Meyer, J.S., and Hansen, J.A., 2002, Subchronic toxicity of low dissolved-oxygen concentrations, elevated $\mathrm{pH}$, and elevated ammonia concentrations to Lost River suckers: Transactions of the American Fisheries Society, v. 131, p. 656-666.

Moyle, P.B, 2002, Inland fishes of California: Berkeley, University of California Press, 502 p.

National Research Council, 2004, Endangered and threatened fishes in the Klamath River Basin-Causes of decline and strategies for recovery: Washington, D.C., The National Academies Press, 398 p.

Neumann, R.M., Guy, G.S., and Willis, D.W., 2012, Length, weight, and associated indices, chap. 14 of Zale, A.V., Parrish, D.L, and Sutton, T.M., eds., Fisheries techniques (3d ed.): Bethesda, Maryland, American Fisheries Society, p.637-676.

Nilsson, G.E., Dymowska, Agnieszka, and Stecyk, J.A.W., 2012, New insights into the plasticity of gill structure: Respiratory Physiology and Neurobiology, v. 184, p. 214-222.

Nilsson, G.E., and Renshaw, G.M.C., 2004, Hypoxic survival strategies in two fishes-Extreme anoxia tolerance in the North European crucian carp and natural hypoxic preconditioning in a coral-reef shark: The Journal of Experimental Biology, v. 207, p. 3,131-3,139.

Post, J. R., and Parkinson, E.A., 2001, Energy allocation strategy in young fish-Algometry and survival: Ecology, v. 82, p. 1,040-1,051.

PhycoTech, 2012, Algae analysis with biovolume estimates report and data set: PhycoTech, St. Joseph, Michigan, $128 \mathrm{p}$.

Pritchard, J.K., Stephens, M., and Donnelly, P., 2000, Inference of population structure using multilocus genotype data: Genetics, v. 155, p. 945-959.

Quist, M.C., Bower, M.R., and Hubert, W.A., 2007, Infection by a black spot-causing species of Uvulifer and associated opercular alterations in fishes from a high-desert stream in Wyoming: Diseases of Aquatic Organisms, v. 78, p. 129-136.

R Core Team, 2012, R-A language and environment for statistical computing: Vienna, Austria, R Foundation for Statistical Computing, http://www.R-project.org/. 
Saiki, M.K., Monda, D.P., and Bellerud, B.L., 1999, Lethal levels of selected water quality variables to larval and juvenile Lost River and shortnose suckers: Environmental Pollution, v. 105 , p. 37-44.

Scoppettone, G.G., Shea, S., and Buettner, M.E., 1995, Information on population dynamics and live history of shortnose suckers (Chasmistes brevirostris) and Lost River suckers (Deltistes luxatus) in Tule and Clear Lake Reservoirs: Reno, Nevada, National Biological Service and Bureau of Reclamation, $91 \mathrm{p}$.

Simon, D.C., Terwilliger, M.R., and Markle, D.F., 2013, Annual report of project-Larval and juvenile ecology of Upper Klamath Lake Suckers - 2012: Corvalis, Oregon State University, $88 \mathrm{p}$.

Svobodova, Z., Lloyd, R., Machova, J., and Vykusova, B., 1993, Water quality and fish health: Rome, Italy, Food and Agriculture Organization of the United Nations, $71 \mathrm{p}$.

Tervonen, V., Vuolteenaho, O., and Nikinmaa, M., 2006, Haemoconcentration via diuresis in short-term hypoxia-A possible role for cardiac natriuretic peptide in rainbow trout: Comparative Biochemistry and Physiology A-Molecular and Intergrative Physiology, v. 144, p. 86-92.

Tringali, M.D., Ziemann, D.A., and Stuck, K.C., 2001, Preliminary aspects of genetic management for Pacific Threadfin Polydactylus sexfilis stock enhancement research in Hawaii, in Nakamura, Y., McVey, J.P., Leber, K., Neidig, C., Fox, S., and Churchill, K., eds., Ecology of aquaculture species and enhancement of stocks, Proceedings of the U.S.-Japan Meeting on Aquaculture, 30th, December 3-4, 2001, Sarasota, Florida: UJNR Technical Report, no. 30, p. 55-74. U.S.

Environmental Protection Agency, 1979a, Methods for chemical analysis of water and wastes: Cincinnati, Ohio, EPA-600/4-79-020, 460 p.

U.S. Environmental Protection Agency, 1979b, Aqueous ammonia equilibrium-Tabulation of percent un-ionized ammonia: Duluth, Minnesota, EPA-600/3-79-091, 428 p.

U.S. Fish and Wildlife Service, 1988, Endangered and threatened wildlife and plantsDetermination of endangered status for the shortnose sucker and Lost River sucker: Federal Register, v. 53, p. 130-134.

Weber, L.P., Higgins, P.S., Carlson, R.I., and Janz, D.M., 2003, Development and validation of methods for measuring multiple biochemical indices of condition in juvenile fishes: Journal of Fish Biology, v. 63, p. 637-658.

Wedemeyer, G.A., Meyer, F.P., and Smith, L, 1976, Diseases of fishes-Book 5Environmental stress and fish diseases: Neptune, New Jersey, T.F.H. Publications, 192 p. Winemiller, K.O., and Taylor, D.H., 1982, Inbreeding depression in the convict cichlid Cichlosoma nigrofasciatum (Baird and Girard): Journal of Fish Biology, v. 21, p. 399-402.

Wolf, J.C., Baumgartner, W.A., Blazer, V.S., Camus, A.C., Engelhardt, J.A., Fournie, J.W., Frasca, Jr., S., Groman, D.B., Kent, M.L., Khoo, L.H., Law, J.M., Lombardini, E.D., RuehlFehlert, C., Segner, H.E., Smith, S.A., Spitzbergen, J.M., Weber, K., and Wolfe, M.J., 2015, Nonlesions, misdiagnoses, missed diagnoses, and other interpretive challenges in fish histopathology studies - A guide for investigators, authors, reviewers, and readers: Toxicologic Pathology, v. 43, p. 297-325.

Zhou, B.S., Wu, R.S.S., Randall, D.J., Lam, P.K.S., Ip, Y.K., and Chew, S.F., 2000, Metabolic adjustments in the common carp during prolonged hypoxia: Journal of Fish Biology, v. 57, p. 1160-1171. 
Publishing support provided by the U.S. Geological Survey

Science Publishing Network, Tacoma Publishing Service Center

For more information concerning the research in this report, contact the Director, Western Fisheries Research Center U.S. Geological Survey

6505 NE 65th Street

Seattle, Washington 98115

http://wfrc.usgs.gov/ 


\section{变}

